PAULO CEZAR CAVALCANTE DE ALMEIDA

\title{
Estudo da transição dermoepidérmica dos enxertos de pele e sua relação com o surgimento de vesículas
}

Tese apresentada à Faculdade de Medicina da Universidade de São Paulo para obtenção do Titulo de Doutor em Ciências

Área de concentração: Cirurgia Plástica

Orientadora: Dra. Mônica Beatriz Mathor

São Paulo

2009 
Dados Internacionais de Catalogação na Publicação (CIP)

Preparada pela Biblioteca da

Faculdade de Medicina da Universidade de São Paulo

Creprodução autorizada pelo autor

Almeida, Paulo Cezar Cavalcante de

Estudo da transição dermoepidérmica dos enxertos de pele e sua relação com o surgimento de vesículas / Paulo Cezar Cavalcante de Almeida. -- São Paulo, 2009.

Tese(doutorado)--Faculdade de Medicina da Universidade de São Paulo.

Departamento de Cirurgia.

Área de concentração: Cirurgia Plástica.

Orientadora: Mônica Beatriz Mathor.

Descritores: 1.Vesícula 2.Transplante de pele 3.Membrana basal 4.Imunofluorescência

USP/FM/SBD-119/09 
"A ciência não pode prever o que vai acontecer. Só pode prever a probabilidade de algo acontecer."

César Lattes (1925 - 2005) (Cesare Mansueto Giulio Lattes) 
Dedico esta tese

Aos meus pais, Célia e Corrêa, aos meus tios, Antônio e Odália e a meu irmão Elias, pelo apoio incondicional e por acreditarem e me ensinarem o valor dos estudos e da dedicação. 


\section{AGRADECIMENTOS}

Aos pacientes vítimas de queimaduras, a quem sempre nos dedicamos, pelo consentimento para realização desse estudo, que sem dúvida alguma foi para uma causa nobre.

Ao Prof. Dr. Marcus Castro Ferreira, Professor Titular da Disciplina de Cirurgia Plástica e Queimaduras da Faculdade de Medicina da Universidade de São Paulo, pela oportunidade e confiança depositados em mim para a execução desse trabalho.

Ao Dr. Leão Faiwichow, amigo e conselheiro, que sempre esteve ao meu lado.

Ao Dr. Walter Soares Pinto, pela amizade e apoio incondicional.

Ao Dr. Deovaldo do Amaral Carvalho, meu grande amigo, pelo apoio, confiança, prestígio e estímulo.

Ao Dr. David de Souza Gomez, meu grande amigo, pelo apoio, orientação dedicação e paciência.

À Dra. Mônica Beatriz Mathor, minha querida orientadora, por sua capacidade, ajuda e dedicação.

Ao Dr. Carlos Alberto Mattar, meu grande amigo, pelo incentivo, ajuda e os momentos de descontração e de boas risadas.

Ao professor Eraldo Lisboa, pela amizade fraterna, dedicação e por aprimorar meus conhecimentos em inglês. 
Ao Dr. José Antonio Luca, amigo de sempre, pelas sugestões e estímulo para a conclusão deste trabalho.

Á Dra. Celeste Imaculada Conceição Gobbi, minha amiga e confidente, pelo apoio e conselhos.

Aos colegas Dr. Gino César C. Arrunátegui, Dr. Wandir Antonio Schiozzer, Dr. Fábio de Freitas Busnardo, Dr. Wilson Cintra Junior e Luiz Philipi Molina (Ph), pela amizade e companheirismo.

Á Dra. Neusa Yuriko Sakae Valente, do Laboratório de Dermatopatologia, pela dedicação na execução deste trabalho.

Dra. Zilda Najar Prado de Oliveira, do Laboratório de Imunopatologia da Divisão de Dermatologia do Hospital das Clínicas da Faculdade de Medicina da Universidade de São Paulo, pela dedicação na execução deste trabalho.

Ao Dr. Bernardo Pinheiro de Senna Nogueira Batista, pelo interesse, ajuda e sugestões ao longo do trabalho.

Ao Sr. Alexandre Marques Périgo, do Laboratório de Imunoflorescência da Divisão de Dermatologia do Hospital das Clínicas da Faculdade de Medicina da Universidade de São Paulo, pela dedicação na execução desse trabalho.

À Dra. Roberta Maria Costa Leite, pela amizade, companheirismo e especial colaboração.

A Sra. Neusa Flores, a amiga de todas as horas, pelo carinho e dedicação de longa data.

Ao Dr. Luiz Steinmann, meu querido mestre, pelo carinho, amizade e por um dia ter acreditado em mim, "in memorian". 
Ao Dr. Úrio Mariani, pela amizade e confiança depositados em mim para o desenvolvimento desse trabalho, "in memorian".

Ao Prof. Dr. Raul do Couto Sucena, meu mestre, com quem aprendi a tratar de queimaduras, "in memorian".

Aos colegas, enfermeiros, fisioterapeutas, psicólogos, assistentes sociais e secretárias, do Serviço de Cirurgia Plástica e Queimaduras do Hospital das Clínicas da Faculdade de Medicina da Universidade de São Paulo.

Aos colegas, enfermeiros, fisioterapeutas, psicólogos, assistentes sociais e secretárias, do Serviço de Cirurgia Plástica e Queimaduras do Hospital do Servidor Público Estadual de São Paulo. 
Esta tese está de acordo com as seguintes normas, em vigor no momento desta publicação:

Referências: adaptado de International Committee of Medical Journals Editors (Vancouver)

Universidade de São Paulo. Faculdade de Medicina. Serviço de Biblioteca e Documentação. Guia de apresentação de dissertações, teses e monografias. Elaborado por Anneliese Carneiro da Cunha, Maria Julia de A. L. Freddi, Maria F. Crestana, Marinalva de Souza Aragão, Suely Campos Cardoso, Valéria Vilhena. $2^{a}$ ed. São Paulo: Serviço de Biblioteca e Documentação; 2005.

Abreviaturas dos títulos dos periódicos de acordo com List of Journals Indexed in Index Medicus. 


\section{SUMÁRIO}

Lista de abreviaturas, símbolos e siglas

Lista de figuras

Lista de tabelas

Lista de anexos

Resumo

Summary

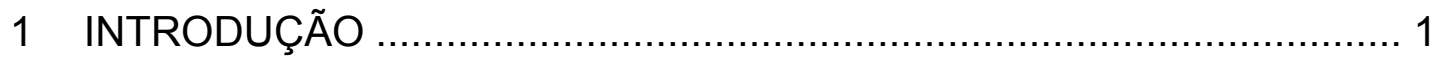

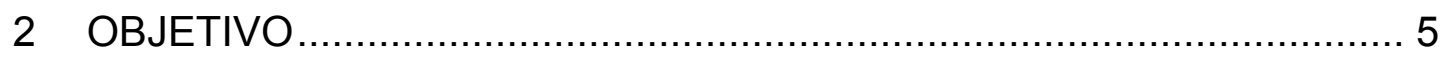

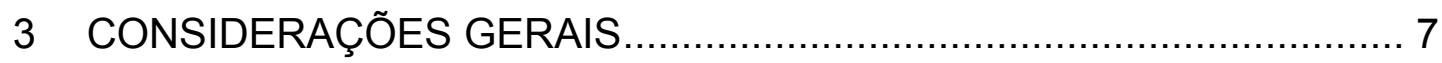

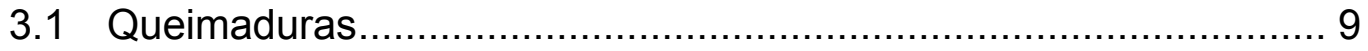

3.2 Pele ............................................................................ 17

3.2.1 Epiderme .......................................................... 19

3.2.2 Membrana Basal .................................................... 24

3.2.3 Derme............................................................ 29

3.3 Funções da pele...................................................... 33

3.4 Ciclo celular da pele .................................................... 34

3.5 Vesículas..................................................................... 35

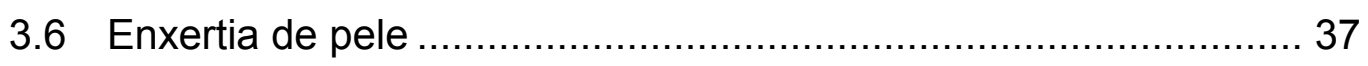

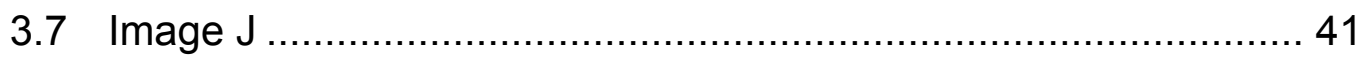

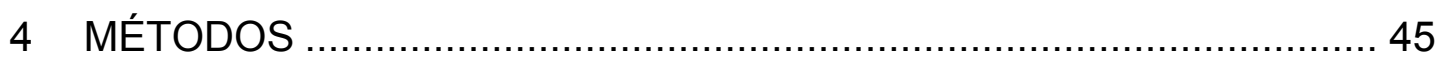

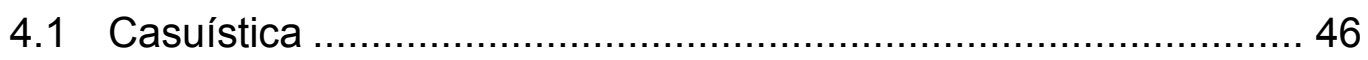

4.2 Biópsias ................................................................. 48

4.3 Estudo Anatomopatológico por Microscopia de Luz .................. 50

4.4 Estudo por Imunofluorescência Direta .................................. 54

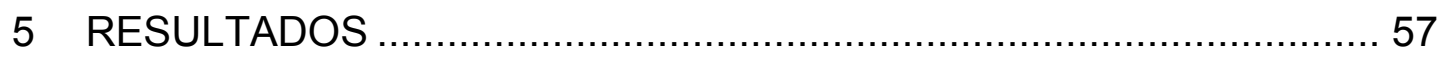

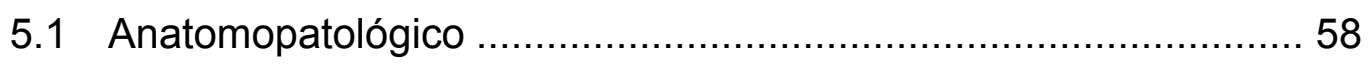

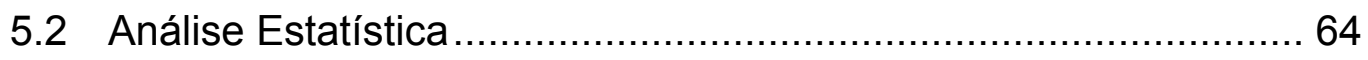

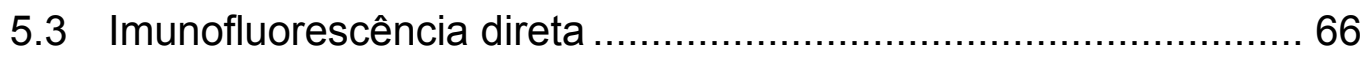


6 DISCUSSÃO

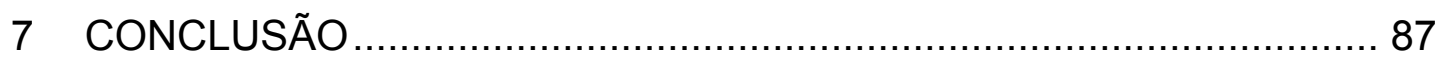

8 ANEXOS

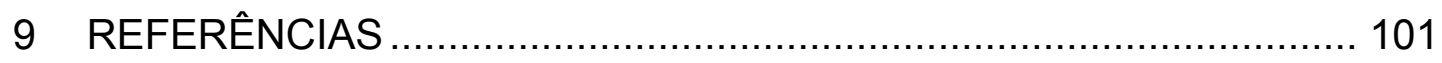

Apêndices 


\section{LISTA DE ABREVIATURAS, SÍMBOLOS E SIGLAS}

\begin{tabular}{|c|c|}
\hline 0 & Grau \\
\hline$\%$ & por cento \\
\hline$=$ & igual a \\
\hline AD & área doadora \\
\hline $\mathrm{cm}$ & Centímetro \\
\hline DOE & Diário Oficial do Estado \\
\hline DOU & Diário Oficial da União \\
\hline Dr. & Doutor \\
\hline Dra. & Doutora \\
\hline e cols. & e colaboradores \\
\hline ENX & Enxerto \\
\hline et. al. & E outros \\
\hline EUA & Estados Unidos da América \\
\hline ex & Exemplo \\
\hline FMUSP & Faculdade de Medicina da Universidade de São Paulo \\
\hline HCFMUSP & $\begin{array}{l}\text { Hospital das Clínicas da Faculdade de Medicina } \\
\text { Universidade de São Paulo }\end{array}$ \\
\hline $\mathrm{KDa}$ & kilo Dalton \\
\hline MB & Membrana basal \\
\hline MEC & matriz extracelular \\
\hline $\mathrm{mg}$ & Miligrama \\
\hline micra & Micra \\
\hline MS & Ministério da Saúde \\
\hline $\mathrm{N}$ & Newton \\
\hline PGs & Proteoglicanos \\
\hline $\mathrm{pH}$ & potencial hidrogeniônico \\
\hline Prof. & Professor \\
\hline Profa. & Professora \\
\hline SBQ & Sociedade Brasileira de Queimaduras \\
\hline SES & Secretaria de Estado da Saúde \\
\hline
\end{tabular}




$\begin{array}{ll}\text { SIM } & \text { Sistema de Informação sobre mortalidade } \\ \text { SUS } & \text { Sistema Único de Saúde } \\ \text { TDE } & \text { transição dermo epidérmica } \\ \text { USP } & \text { Universidade de São Paulo } \\ \text { ZMB } & \text { zona da membrana basal } \\ \mu m & \text { Mícron } \\ \text { AIH } & \text { autorização para internação hospitalar } \\ \text { DATASUS } & \text { banco de dados do Sistema Único de Saúde } \\ \text { a.C. } & \text { antes de Cristo } \\ \text { TABWIN } & \text { Tabulação e tratamento de dados do SUS através do } \\ m^{2} & \text { programa Tab para Windows } \\ \text { mm } & \text { metro quadrado } \\ \text { CTQ } & \text { Milímetro } \\ \text { GAGs } & \text { Centro de tratamento de queimaduras } \\ \text { P105 } & \text { Glicosaminoglicanos } \\ \text { BP180 } & \text { Proteína da membrana basal } \\ \text { kg } & \text { Antígeno do penfigóide bolhoso } \\ \end{array}$




\section{LISTA DE FIGURAS}

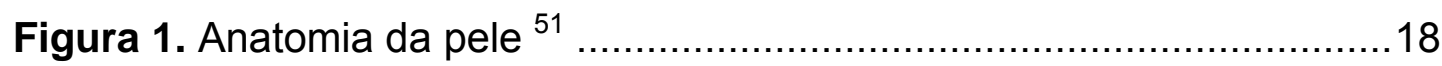

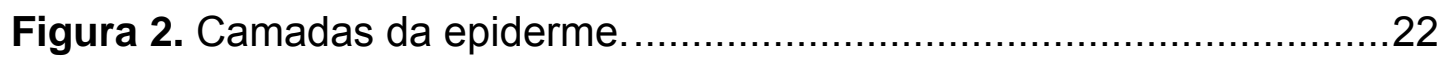

Figura 3. Membrana Basal (MB) ou Zona da Membrana Basal (ZMB) ........26

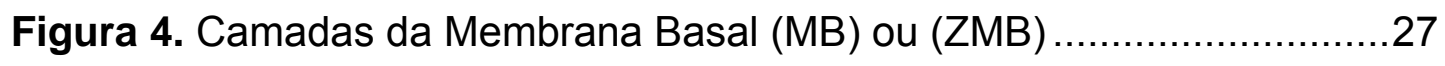

Figura 5. A membrana basal, suas camadas e seus ligamentos: na epiderme e na derme.

Figura 6. Sequência da formação de vesículas e ilustração, na epidermólise bolhosa distrófica onde há alteração na estrutura Transição dermo-epidérmica .

Figura 7. Quadro comparativo do Image Tool com o Image J

Figura 8. Dermátomo elétrico

Figura 9. Quadro ilustrativo do método utilizado para a realização das biópsias.

Figura 10. Fotografia da visualização da camada granulosa e da transição dermoepidérmica (TDE)

Figura 11. Barra de ferramentas do Image $\mathrm{J}$ com as diversas funções executadas pelo programa

Figura 12. Fotografia da varredura feita pelo Image $\mathrm{J}$ em EPI e TDE de AD e ENX com aumento de 100X.

Figura 13. Fotografia da pele sã, amostra $A D$, onde todas as estruturas da epiderme e derme são visíveis inclusive as papilas dérmicas

Figura 14. Fotografia da Área enxertada, amostra ENX, onde todas as estruturas da epiderme e derme são visíveis inclusive as papilas dérmicas

Figura 15. Gráficos das medidas lineares onde constam em (A) as medidas de TDE e EPI em AD, em (B) as medidas da TDE e EPI em 
ENX e em (C) relação do comprimento da TDE e da EPI por meio do índice TDE/EPI=N de AD e ENX.

Figura 16. Gráfico com valores individuais e médias em cada momento

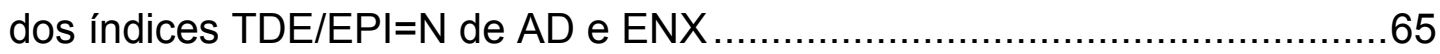

Figura 17. Fotografia da $A M B$ da $A D$ com aumento de 160X. Camada de hemidesmossomos

Figura 18. Fotografia da AMB de ENX com aumento de 160X. Camada de Hemidesmossomos

Figura 19. Fotografia da $A M B$ de $A D$ com aumento de 160X. Lâmina lúcida

Figura 20. Fotografia da ZMB de ENX com aumento de 160X. Lâmina lúcida

Figura 21. Fotografia da ZMB de AD com aumento de 160X. Lâmina densa

Figura 22. Fotografia da ZMB de ENX com aumento de 160X. Lâmina densa.

Figura 23. Fotografia da ZMB de AD com aumento de 160X. Sublâmina densa.

Figura 24. Fotografia da ZMB de ENX com aumento de 160X. Sublâmina densa 


\section{LISTA DE TABELAS}

Tabela 1 - História do tratamento das queimaduras 10

Tabela 2. Revisão literária realizada por Gomez em 2005

Tabela 3. Casuística contendo idade, sexo, tempo decorrido para a segunda biópsia (PO), área doadora e área enxertada

Tabela 4. Resultado das medidas lineares obtidas através da varredura do Image $\mathrm{J}$ e da relação TDE/EPI=N de AD

Tabela 5. Resultado das medidas lineares obtidas através da varredura do Image $\mathrm{J}$ e da relação TDE/EPI=N de ENX

Tabela 6 - Resultado da relação (TDE/EPI ENX) / (TDE/EPI AD) x 100. Este resultado mostra aumento do índice dos enxertos em relação a área doadora em média de $24 \%$

Tabela 7. Diferenças entre as medidas descritivas dos índices das medidas lineares de AD e ENX e os percentuais resultantes

Tabela 8. Resultado das análises estatísticas das medias descritivas de AD e ENX

Tabela 9. Resultado da imunofluorescência direta e imunomapeamento da Membrana Basal das amostras das áreas doadoras

Tabela 10. Resultado da imunofluorescência direta e imunomapeamento da Membrana Basal das amostras dos enxertos 


\section{LISTA DE ANEXOS}

Anexo A - Termo de Consentimento Livre e Esclarecido......................... 90

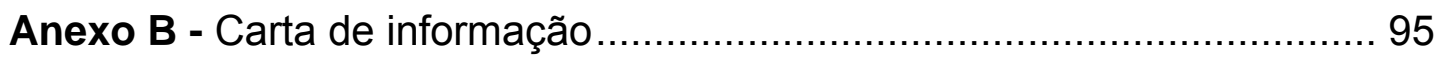

Anexo C - Aprovação da Comissão de Ética para Análise de projetos de Pequisa CAPPesq ............................................................................ 98

Anexo D - Tabela gerada pelo DATASUS/TABWIN - Produção Hospitalar em 13 de fevereiro de 2009, de acordo com o CID 10 (Queimadura), enviada como anexo no e-mail citado na referência 37 99

Anexo E - Tabela gerada pelo SIM (Sistema de Informação sobre Mortalidade), Ministério da Saúde 100 


\section{RESUM0}

Almeida PCC. Estudo da transição dermoepidérmica dos enxertos de pele e sua relação com o surgimento de vesículas [tese]. São Paulo: Faculdade de Medicina, Universidade de São Paulo; 2009. 111p.

O presente estudo foi realizado para esclarecer o surgimento de vesículas subepidérmicas em enxertos de pele comumente descritos como "áreas enxertadas". Devido à discrepância existente entre a literatura, que afirma surgirem vesículas nessas áreas, e a nossa experiência clínica, onde não observamos tal fato, decidimos investigar o problema. Para isso, estudamos a transição dermoepidérmica (TDE), em 23 pacientes submetidos à enxertia de pele, para verificar se há ou não alteração dessa estrutura que pudesse justificar a formação de vesículas. Nos 23 pacientes estudados foram feitas duas biópsias: a primeira, imediatamente antes da excisão do enxerto, na área doadora - pele sã, considerada como amostra padrão normal da TDE - Amostra Padrão - AD. Após 10 dias, realizou-se uma segunda biópsia, com o mesmo vazador, próxima à área da primeira biópsia - Amostra Teste - ENX. Cada amostra foi dividida em 2 partes iguais (46 amostras) e estudadas por microscopia de luz e por imunofluorescência direta (imunomapeamento), pesquisando-se a possível alteração da zona da membrana basal (ZMB) na TDE através dos antígenos penfigóide bolhoso, laminina, colágeno IV e colágeno VII. Na microscopia de luz estudou-se, em cada biópsia, a relação entre a medida linear do relevo da trasição dermoepidérmica e a medida linear do relevo da superfície da camada granulosa, logo abaixo da camada córnea, equivalente a medida linear da superfície da pele. Nas 46 amostras as análises por microscopia de luz e de imunomapeamento para os quatro antígenos evidenciou-se a manutenção do mesmo padrão morfológico. Não houve diferença no imunomapeamento. Observou-se relações lineares das medidas com médias de 1,17 para a amostra AD e 1,44 para a amostra ENX, diferença que foi estatisticamente significativa, porém conservando a manutenção do padrão da TDE em relação à pele normal. Foi observada a manutenção do padrão do relevo da TDE no enxerto, em relação à pele sã, doadora.

Unitermos: 1.Vesícula 2.Transplante de pele 3.Membrana basal 4.Imunofluorescência 


\section{SUMMARY}

Almeida PCC. A study of skin grafts dermal-epidermal junction and its relation to the onset of blisters [thesis]. São Paulo: "Faculdade de Medicina, Universidade de São Paulo"; 2009. 111p.

SUMMARY: The present study has been done to elucidate the onset of subepidermal blisters in skin grafts, usually mistaken as "grafted sites". Due to the discrepancy between literature - assigning this onset of blisters in grafts - and our experience - opposite - we have decided to carry out this study. To do so we have studied the dermal-epidermal junction in 23 burned patients who underwent skin grafting so that we could verify whether or not there could be any alteration in the dermal-epidermal junction structure that may explain this fact. Among the 23 studied patients, two biopsies were carried out: the first one just before harvesting the skin graft from donor site - healthy skin. The so called sample was regarded as an ordinary standard one of the dermal-epidermal junction - STANDARD SAMPLE DS. After graft take, by ten days, a second biopsy was performed with the same punch, close to the first biopsy - TEST SAMPLE - GS. Both samples were split into two equal parts (46 samples) and studied using light microscopy and direct immunofluorescence (immune mapping), searching for possible alterations in basement membrane zone in the dermal-epidermal junction through bullous pemphigoid, laminin and types IV and VII collagen antigens. On light microscopy, relation between the linear measure of dermal-epidermal junction projection and that of stratum granulosum surface, just underneath the stratum corneum, corresponding to skin surface, was studied in each biopsy. The four analyses of the antigens by light microscopy and direct immunofluorescence in the 46 samples clearly showed the keeping of the same pattern, either for STANDARD SAMPLE - DS or TEST SAMPLE - GS. There were no differences on the immune mapping. Regarding the relation of the linear measures it was noted a mean of 1.17 for STANDARD SAMPLE - DS and a mean of 1.44 for TEST SAMPLE - GS. Such difference was statistically significant. Nevertheless, it maintained the keeping of the same pattern of dermal-epidermal junction when compared to healthy skin.

Descriptors: 1.Blister 2.Skin transplantation 3.Basement membrane 4.Fluorescent antibody technique 
1 INTRODUÇÃO 
Em 1984 Gallico e col. ${ }^{1}$ realizaram pela primeira vez, em âmbito clínico, enxertia de pele cultivada para tratar queimaduras, entretanto a má aderência dos enxertos, que levou à formação de bolhas e vesículas seguidas de ulcerações, tornou o resultado da enxertia insatisfatório.

Os índices de integrações dos enxertos epidérmicos com pele cultivada citados por O'Connor 2 , Cuono 3, De Luca 4, Teepe 5 e Donati 6, variam entre 10 e $50 \%$ do total da área enxertada. Essa má aderência tem sido atribuída a falhas na reconstrução da transição dermo-epidérmica (TDE).

A busca de um substitutivo dermoepidérmico com aderência apropriada vem sendo intensamente pesquisada, sem sucesso. A bibliografia é imensa e na disciplina de Cirurgia Plástica e Queimaduras o assunto vem sendo estudado e levou a uma tese em $1999^{7}$, sobre cultivo de células epidérmicas em derme alógena humana.

Apesar da abundância de trabalhos estudando a aderência epidérmica, pouca atenção tem sido dada às vesículas subepidérmicas originadas nos tegumentos neoformados, que podem surgir na cura das queimaduras onde não houve enxertia de pele, nas quais se evidencia a falha dessa aderência.

Assim, a revisão da literatura no período de 1980 a 2004, consta apenas de 8 trabalhos ${ }^{8,9,10,11,12,13,14,15}$, estudando 31 doentes com 34 casos de vesículas.

Esta revisão originou o trabalho "The problem of subepidermal 
blisters in neoformed integuments" 16, que discute a formação de vesículas em tegumentos neoformados e a discrepância existente na literatura, que afirma surgirem vesículas em áreas de enxertia de pelo, comumente descritas como "áreas enxertadas" -, confundindo-as com os próprios enxertos de pele.

$\mathrm{Na}$ nossa experiência clínica não observamos o surgimento de vesículas em enxertos de peleo e decidimos investigar o problema de forma a desfazer esse equívoco frequente.

A literatura acusa que 19 casos (56\%) de vesículas ocorreram em enxertos o que está em desacordo com o estudo de Mariani e cols., em cem doentes queimados curados ${ }^{17}$, onde não foi verificado nenhum caso de vesícula nos enxertos.

Esse fato corrobora nossa experiência clínica assim como a de Jo David Fine ${ }^{12}$ - co-autor do trabalho de Epstein ${ }^{18}$ - que refere não ter encontrado vesículas em 600 casos de enxertia.

Analisando os 4 trabalhos que referem vesículas nas áreas enxertadas - grafted sites - 10,12,14,15 não encontramos evidências de vesículas nos enxertos.

Considerando que na área enxertada só pode existir enxerto e cicatriz, e não se comprovando que as vesículas se originam no enxerto, admiti-se que se originam da cicatriz.

Esta hipótese tem a favor a suscetibilidade dos tegumentos resultantes de epitelização à formação de vesículas atribuídas à imperfeita neoformação da transição dermo-epidérmica, onde se localiza 
a zona da membrana basal (ZMB).

Dentre os tegumentos neoformados suscetíveis à formação de vesículas podemos citar as áreas de pele restaurada, como as doadoras de enxertos de pele de espessura parcial (apêndice 4), queimaduras de segundo grau curadas (Apêndice 2), as áreas cicatrizadas (Apêndice 3) como as epitelizações das áreas de transição entre os enxertos de pele e a pele sã, áreas dos interstícios dos enxertos em malha epitelizados (Apêndice 5) e em enxertias de epiderme cultivada. Nesta última é nítido que a má aderência desses enxertos, provavelmente devido à falha na reconstrução da transição dermo epidérmica, leva à formação de bolhas seguidas de ulcerações que tornam inadequado o resultado da enxertia.

Os enxertos e pele de espessura parcial constituídos por epiderme, papilas dérmicas e membrana basal normais seriam menos susceptíveis à formação dessas vesículas. Esta hipótese necessitava investigação. Assim, realizou-se estudo anatomopatológico para investigação da normalidade da transição dermo-epidérmica, quanto à manutenção das papilas dérmicas, e o estudo imunoistoquímico para averiguação da integridade anatômica e funcional da zona da membrana basal, nos enxertos de pele, comparandoos com TDE da pele sã. Dessa forma, foi verificado a integração do enxerto, de alguma forma, poderia alterar essas propriedades e causar prejuízo na função da TDE.

Não encontramos na literatura indexada referência a alterações da membrana basal de enxertos de pele. 
2 OBJETIVO 
Demonstrar que não se formam vesículas nos enxertos de pele, estudando a transição dermoepidérmica destes, comparando-os com a transição dermoepidérmica da pele sã, doadora, por meio dos padrões morfológicos e imunomapeamento. 
3 CONSIDERAÇÕES GERAIS 
Há poucos anos atrás discutíamos, na Divisão de Queimaduras do Hospital das Clínicas da Faculdade de Medicina da Universidade de São Paulo (HCFMUSP), sobre enxertias de pele e o alegado surgimento de vesículas em enxertias de pele mencionado por alguns autores. O assunto, pouco esclarecido na literatura e polêmico para todos, voltou a ser comentado outras vezes.

Numa dessas discussões surgiu a proposta de realizarmos um trabalho a respeito deste tema. Essa proposta se concretizou e deu origem a um protocolo de pesquisa que começou a ser esboçado. Após vários estudos foi aprimorado e desenvolvido. Pouco tempo depois o apresentamos à Faculdade de Medicina como tema dessa tese, na linha de pesquisa da pele, e após sua aprovação, começamos a executá-lo.

Hoje, após essa pesquisa ter se concluído, defendemos nossa tese. Aqui rendemos uma homenagem ao idealizador desse trabalho: Dr. Úrio Mariani, "in memorian" (apêndice 1). 


\subsection{Queimaduras}

A história do tratamento das queimaduras remonta à pré-história e é tão antiga quanto a humanidade. Na Pré-História, há 150 milhões de anos, surgiu o Pithecanthropus erectus. Ele desenvolveu a fala e conheceu o fogo através de raios, vulcões e terremotos, que geravam ainda grandes mudanças no planeta. O fogo era roubado da natureza, pois ele não possuía conhecimento para reproduzi-lo. Foi seguido do Ramapithecus e do hominídeo, Australopithecus e depois do Homo habilis, que em sua trajetória descobre a técnica de fazer o fogo usando ferramentas de pedra lascada ${ }^{19}$.

O Homo erectus aperfeiçoa esta técnica, mantendo o fogo aceso em condições ambientais hostis, utilizando a resina de eucalipto. Estes se espalharam pela Ásia, África e Europa onde surge o homem de Neanderthal na Alemanha e o Cro-Magnon na França ${ }^{19}$.

O homem de Neanderthal tratou de queimaduras com extrato de plantas, os egípcios com uma mistura de látex e leite de cabra e os chineses com tinturas e extratos feitos de chá. Ao longo da evolução da civilização outras terapêuticas foram propostas como o uso do ácido tânico, mel e farelo, uso de cinzas, vinagre ou vinho, pomadas de gordura animal, e outras tantas, todas na intenção de se realizar o cuidado local e a cura das queimaduras 20.

Os estudos sobre queimaduras começam a surgir no século XIV quando William Clowes publica o primeiro livro que fala sobre o assunto e descreve os efeitos das queimaduras por pólvora. Segue-se a famosa publicação do inglês Edward Kentish "Ensaio sobre Queimaduras” em 1797. 
Também nesta época, por volta do ano de 1828, o francês Jean Nicolas Marjolin, descreve "cicatrizes que apareciam após queimaduras como cânceres", que hoje sabemos serem os carcinomas de células escamosas, de comportamento agressivo, que surgem em queimaduras antigas, conhecidas como úlcera de Marjolin ${ }^{20,21}$, (Tabela 1).

Esses foram os primórdios da pesquisa no campo das queimaduras, que evoluíram com trabalhos realizados na Alemanha, Grã-Bretanha e França. No entanto, foi nos Estados Unidos, em 1921, que Frank P. Underhill realizou o primeiro estudo sobre a perda de líquidos em pacientes queimados.

Tabela 1 - História do tratamento das queimaduras ${ }^{22}$

\begin{tabular}{ll}
\hline Homem de neanderthal & Extrato de plantas \\
Egípcios 1500 a.C. & $\begin{array}{l}\text { Látex e leite de cabra misturado com leite materno e faixas. } \\
\text { Faixas embebidas em óleo. }\end{array}$ \\
Chineses (600 - 500 a.C.) & Extrato de folhas de chá \\
Hipócrates (430 a.C.) & Sêmen suíno, resina e betume. \\
Celsus (Roma antiga) & Mel e farelo de trigo \\
Galeno (Roma antiga) & Vinagre ou vinho \\
Rhases (século IX) & Água fria \\
Paré (1517-1598) & Excisão e ungüentos \\
David Cleghorn (1792) & Vinagre e cataplasma \\
Edward Kentish (1797) & Curativos sob pressão \\
Syme (1827) & Curativos de lã \\
\hline Lisfranc (1835) & Curativos de cloridrato de cálcio \\
\hline
\end{tabular}


Em 1952 Evans, de Richmond, propõe a primeira fórmula de reposição hídrica baseada no peso corporal e na superfície queimada. A seguir surgiram outras fórmulas para hidratação, com a finalidade de impedir o choque hipovolêmico do queimado.

Alguns anos após, os cirurgiões da Unidade de Pesquisas Cirúrgicas do Centro Médico Militar de Brooke, modificaram a fórmula de Evans e iniciaram o uso de solução salina e colóide. Em seguida, Shires e Baxter, estudaram o uso de soluções salinas balanceadas no hospital de Parkland e desenvolveram outra fórmula utilizando somente solução de Ringer-Lactato nas primeiras 24 horas pós-queimadura ${ }^{20,22}$.

O uso de medicação tópica e de curativos para queimados também evoluiu durante o século passado. A gaze petrolada foi primeiramente utilizada por Harvey Allen nos EUA em $1942^{23}$.

Em 1953, Liedberg, Ress e Artz, afirmaram que "a sepse era a principal causa de morte dos pacientes queimados" e, a partir desta afirmação, iniciase o uso do tratamento tópico das queimaduras com antibióticos. Começam a surgir agentes capazes de penetrar a cicatriz da ferida e minimizar o desenvolvimento de bactérias sob a superfície queimada ${ }^{24}$.

O primeiro antimicrobiano tópico elaborado foi o acetato de mafenide, testado por Moncrief e Lindberg. Ao mesmo tempo, Moyer inicia o uso do nitrato de prata a $0,5 \%$. Chales Fox compõe o creme de sulfadiazina de prata e o populariza na década de 1960. Na década de 1970, Monafo introduz o nitrato de cério e sulfadiazina de prata como agente tópico para tratamento das infecções ${ }^{20}$. 
Nessa época, as investigações quanto ao uso de curativos e o melhor tipo de tratamento para as queimaduras ficaram em evidência e geraram grandes debates. Os estudiosos discutiam os melhores métodos de oclusão e exposição para o tratamento de pacientes queimados, que já no século dezenove (1877) havia sido proposto por Copeland ${ }^{25}$.

Os enxertos de pele, fundamentais para o tratamento das queimaduras profundas, são relatados pela primeira vez na Idade Média por Tilemaker (Índia) que realiza os primeiros enxertos livres de pele total ${ }^{26}$.

Gaspare Tagliacozzi, da Universidade de Bologna (Itália), considerado o pioneiro na cirurgia plástica, no século XVI, usa retalhos e enxertos de pele para tratamento do nariz. Reverdin, em 1869 na Suíça, pratica o primeiro enxerto de epiderme. Os enxertos dermoepidérmicos são descritos por Ollier e Thiersch em 1874 como enxertos espessos de epiderme. No começo do século passado, John Davis preconiza a prática dos enxertos em tenda de campanha, que passam a ser utilizados por muitos cirurgiões ${ }^{25}$.

Blair e Brown, na década de 30 , retiram enxertos à mão livre e ensinam muitos cirurgiões a utilizar essa técnica. Surge, em 1939, o primeiro dermátomo a tambor idealizado por Padgett. Durante a segunda guerra mundial o dermátomo elétrico é desenvolvido por Brown. Em 1965, Hargest modifica o dermátomo de Brown e substitui o motor elétrico por um motor movido a $\operatorname{ar}^{20}$.

Desde então, uma série de estudos clínicos e cirúrgicos começam a ser realizados em todo mundo e o tratamento das queimaduras ganha novos horizontes e evolui. 
As queimaduras são acidentes frequentes em nosso meio e possuem várias causas e agentes etiológicos. São muito comuns os acidentes domésticos com líquidos aquecidos ou inflamáveis (álcool, gasolina, entre outros). As crianças, nos países em desenvolvimento, são as maiores vítimas dessa condição. Os traumas elétricos, as tentativas de autoextermínio, os acidentes de trabalho, as queimaduras químicas, por contato e as radiações, também estão entre as principais causas de queimaduras. Ainda podemos mencionar as congeladuras e as abrasões como causas de queimaduras $27,28,29,30,31$.

A queimadura é um trauma e sua tendência é aumentar cada vez mais, devido à violência, às más condições de habitação e à situação sócioeconômica desfavorável que possui a maior parte da população no Brasil e no mundo 27,28

As queimaduras causam respostas emocionais intensas tanto na população leiga como nos profissionais da saúde, os quais enfrentam grandes desafios no seu tratamento. A dor causada pelo trauma, os inúmeros curativos, os repetidos episódios de sepse, as várias cirurgias, o risco potencial de morte e a deformidade após a cura, são alguns desses desafios. As sequelas, muitas vezes indeléveis, já começam a surgir, durante a fase aguda do tratamento. Estas resultam na alteração da imagem corporal, gera incapacidade física, e contribui para o agravamento do componente biopsicossocial nas vítimas de queimaduras ${ }^{20,29,30,32,33}$.

Não bastasse o sofrimento ocasionado pela queimadura e o surgimento das sequelas, o doente queimado ainda é estigmatizado e 
discriminado pelos médicos, administradores hospitalares, para-médicos e leigos. Não há qualquer causa racional para essa conduta. Talvez as causas sejam as mesmas que estigmatizam outros doentes com lesões de pele, como os hansenianos e os portadores de fogo selvagem ${ }^{29}$.

Mariani, $1995{ }^{34}$, relata que "talvez no Brasil as vítimas de queimaduras tenham tido, por muito tempo, o pior atendimento entre todos os doentes traumatizados no país", mas que este fato não foi comum só no Brasil. A enciclopédia Britânica (1979) dizia ser o tratamento das queimaduras, em todo o mundo, o campo da medicina que menos evoluiu e, que era habitual, ser o tratamento das queimaduras mal conduzido (apud). Porém, hoje este panorama mudou.

Até o ano 2000, o tratamento de pacientes portadores de queimaduras não possuía nenhuma normatização federal. O estado de São Paulo foi o pioneiro em publicar no Diário Oficial do Estado a Resolução SS n 624 de 20 de Dezembro de 1994, sob o título: "Normas Técnicas para o Atendimento de Queimaduras no Sistema de Saúde do Estado de São Paulo" ${ }^{35}$.

Essas normas, ainda em vigor, visam à padronização do tratamento das queimaduras no estado de São Paulo e também estabelecem um modelo de como deve ser organizada uma Unidade de Tratamento de Queimaduras. A partir dessa publicação da Secretaria da Saúde do Estado de São Paulo, o governo federal iniciou, em 1999, um protocolo de estudo sob as condições do tratamento do queimado no país. Também, nessa época, houve solicitação da recém criada Sociedade Brasileira de 
Queimaduras (1995), para que o tratamento das queimaduras fosse normatizado. Para esse fim, o Ministério da Saúde criou um grupo de estudos e definiu normas e diretrizes a serem adotadas no tratamento de queimaduras $^{35}$.

Em 20 de novembro de 2000, o Ministério da Saúde (MS) publica os estudos feitos pela Secretaria de Assistência à Saúde e da Coordenação da Alta Complexidade, hoje Secretaria de Atenção à Saúde e Coordenação da Alta e Média Complexidade, nas Portarias GM n 1273 e 1274 , de 20 de novembro de $2000^{36}$. Essas portarias, que foram republicadas por terem saído com incorreções, criaram "mecanismos para a organização e implantação de Redes Estaduais de Assistência a Queimados em todo o Brasil” e também "estabeleceram uma nova Tabela de Procedimentos no SUS" ${ }^{36}$.

Após o ano 2000, o paciente queimado, que permanecia à margem do Sistema Único de Saúde - SUS, ganhou a devida importância e teve seu lugar garantido entre a política de saúde pública regulamentada e conduzida pela Coordenação Geral da Alta e Média Complexidade ${ }^{36}$.

Nesta ocasião, foram habilitados 33 Centros de Tratamento de Queimaduras (CTQs) no Brasil, que iniciaram a formação da rede nacional de atendimento ao queimado. Com essa rede os CTQs passaram a ter remuneração diferenciada, nova estrutura física, funcional e a oficialização da atuação de equipes multiprofissionais para o tratamento das queimaduras $^{36}$. 
Hoje, o atendimento dos pacientes queimados no Brasil está normatizado e diferente do que foi no passado. O número de óbitos diminuiu consideravelmente e o tratamento das queimaduras passou a ter outro enfoque, não só por parte dos profissionais atuantes na área, como também da sociedade ${ }^{38}$.

Recentemente, novas medidas foram adotadas pelo Ministério da Saúde. Houve alteração e melhoria da Tabela de Procedimentos Cirúrgicos do SUS e inclusão de novos materiais na Tabela de Órteses, Próteses e Materiais ${ }^{38}$

O Ministério da Saúde, no ano de 2006, registrou, por meio das Autorizações de Internação Hospitalar (AIHs), da rede pública do SUS em Hospitais Gerais e Centros de Referência para Tratamento de Queimaduras, 34.547 internações de pacientes queimados, que geraram 241.259 dias de permanência em leitos de enfermaria, 17.614 diárias de UTI, 5.957 procedimentos cirúrgicos e 843 óbitos, no Brasil ${ }^{37}$.

Dados da Sociedade Brasileira de Queimaduras estimam que aproximadamente 1.000 .000 de acidentes por queimaduras ocorram por ano no Brasil, destes, 100.000 procurarão atendimento Hospitalar e 2.500 irão falecer direta ou indiretamente de suas lesões. Estes dados são proporcionalmente similares aos publicados por outros países em desenvolvimento, porém diferem consideravelmente dos países do primeiro mundo $39,40,41,42,43,44,45,46$. 


\subsection{Pele}

A pele é o órgão que envolve o corpo e determina seu limite com o meio externo. Representa a primeira linha de defesa do organismo e, ao mesmo tempo, mantém sua homeostase ${ }^{47}$.

Tem em média, no adulto, uma área de $2 \mathrm{~m}^{2}$, pesa aproximadamente $2,7 \mathrm{Kg}$, recebe $1 / 3$ do volume de sangue circulante e suas funções são vitais para a manutenção dos mecanismos de defesa contra doenças. Tem em geral a espessura de 75 a 150 mícrons $(\mu \mathrm{m})$, mas chega a uma espessura de 400 a 600 um na palma das mãos e na planta dos pés ${ }^{48}$.

A pele excreta água e produtos metabolizados que participam da regulação da temperatura corporal, contém terminações nervosas sensitivas, contribui para o feedback sensorial, protege o organismo contra ferimentos e realiza a defesa contra organismos patógenos. Para este fim, a pele conta com componentes celulares e humorais do sistema imunológico e dos diversos sistemas de defesa contra microorganismos ${ }^{49}$.

Em algumas ocasiões, o sistema imunológico é causa de lesões na pele e pode resultar na perda devastadora da integridade tissular e em doenças, tais como: a síndrome de Stevens-Johnson e o Pênfigo bolhoso ${ }^{50}$. 


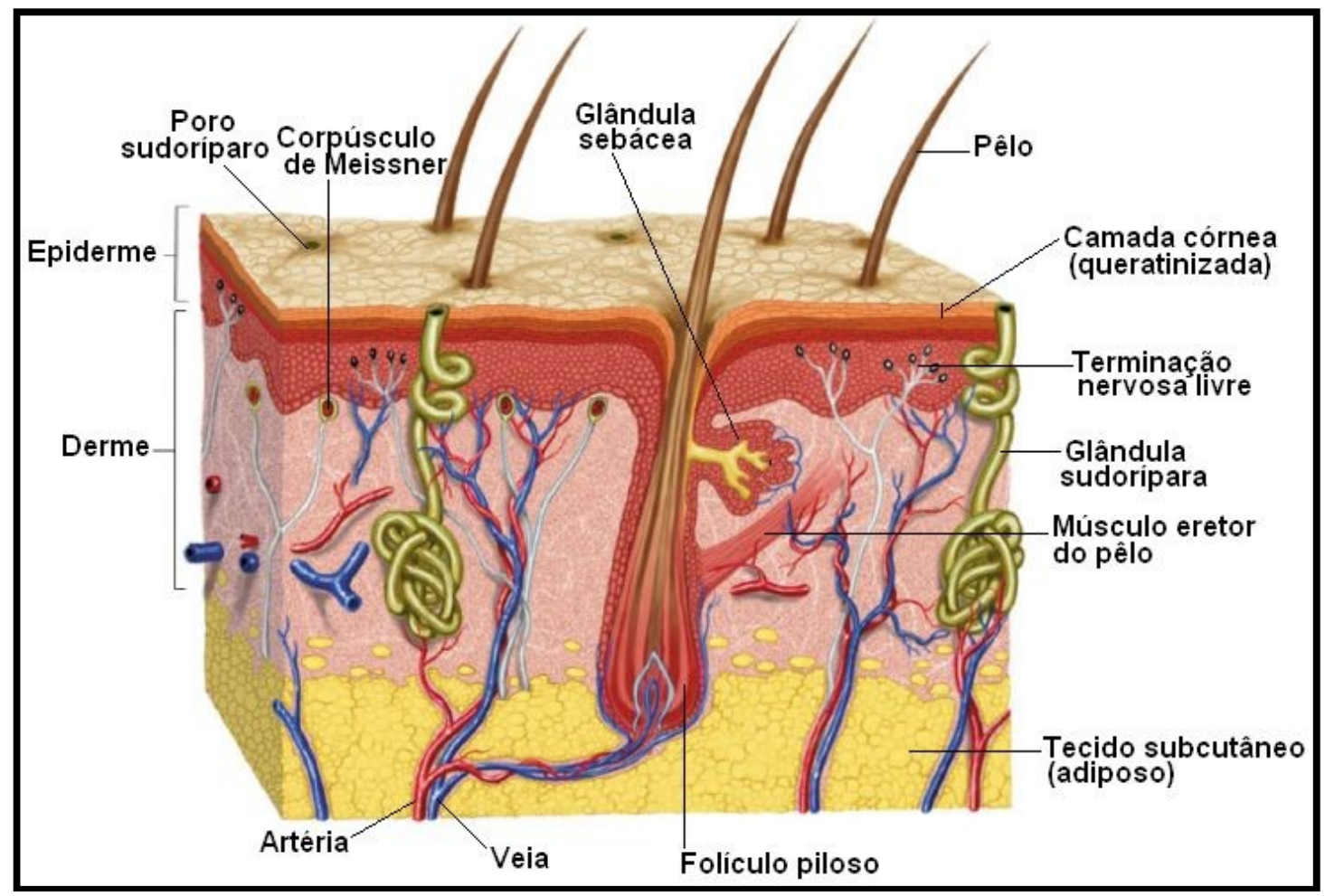

Figura 1. Anatomia da pele ${ }^{51}$

É formada por duas camadas primárias coesas: epiderme e derme (Figura 1). A camada de tecido adiposo subcutânea, situada abaixo da derme, também conhecida como hipoderme, tem a mesma origem da derme mas não faz parte da pele. A hipoderme aumenta o isolamento da pele, é responsável pelo suporte e união com os órgãos adjacentes e a protege de lesões de pressão ou estiramento entre as protuberâncias ósseas sobre as quais o indivíduo repousa ${ }^{50}$.

No embrião, a pele tem origem na fase de blastoderme a partir de seu folheto externo, a ectoderme, da qual derivam o sistema nervoso, os órgãos dos sentidos e a epiderme e seus anexos. A morfogênese da pele e de todos os seus componentes está parcialmente terminada no final do terceiro 
trimestre, com exceção da gênese das glândulas sudoríparas. A diferenciação da epiderme e de todos seus apêndices ocorre durante o terceiro trimestre ${ }^{52}$.

A derme, diferentemente da epiderme, tem um complexo processo de formação. Sua origem varia de acordo com o local do corpo em que esta havendo a diferenciação das células mesenquimais dérmicas. Por exemplo, o mesênquima dérmico da face e do couro cabeludo anterior se origina da crista neural ectodérmica. Por outro lado, o mesênquima dérmico do dorso se origina do dermatocitoma embriogênico, enquanto que o mesênquima dérmico das extremidades e da face ventral do tronco se origina do folheto mesodérmico lateral ${ }^{52,53,54}$.

Os apêndices dérmicos têm componentes dérmicos e epidérmicos e o desenvolvimento normal desses apêndices depende de uma interação coordenada e rigorosa de ambas, epiderme e derme, em formação ${ }^{52}$.

\subsubsection{Epiderme}

A epiderme é constituída por epitélio estratificado pavimentoso queratinizado, composto por células escamosas dispostas em várias camadas. A célula principal é o queratinócito, que produz a queratina. A queratina é uma proteína resistente e impermeável responsável pela proteção (barreira física). Os queratinócitos são células diferenciadas do tecido epitelial e representam $80 \%$ das células da epiderme ${ }^{55}$. 
Outros componentes da epiderme são as células de Langerhans e células de Merkel. As células de Langherans são células móveis e dendríticas responsáveis pela imunovigilância cutânea. Foram descobertas, em 1868, pelo estudante de medicina Paul Langerhans ${ }^{56,57}$.

As células de Langherans permaneceram com suas funções desconhecidas até a década de 1960, quando houve desenvolvimento da imunoistoquímica, que permitiu descobrir várias de suas funções imunológicas ${ }^{54}$. Têm a função de captar, processar e apresentar os antígenos aos linfócitos $\mathrm{T}$, que são incapazes de reconhecê-los por si mesmos. Esses linfócitos, uma vez ativados, multiplicam-se e produzem citoquinas ${ }^{57,58,95}$.

Representam 3-6\% de todas as células epidérmicas. Contêm um marcador citoplasmático específico, os grânulos de Birbeck, que estão aparentemente relacionados com o processo de endocitose de partículas estranhas. As células de Langerhans apresentam um baixo potencial de proliferação celular no interior do tecido epitelial. Estas células, no epitélio, não resultam na sua maioria de um processo de renovação celular, mas sim, da migração de novas células progenitoras oriundas da medula óssea ${ }^{55}$.

As células de Merkel estão em contato com fibras amielínicas que penetram a membrana basal e terminam em forma de discos (discos de Merkel). Formam terminações nervosas livres especializadas, conhecidas como corpúsculos de Merkel. As células de Merkel apresentam, em proximidade às terminações nervosas, vesículas citoplasmáticas semelhantes 
às vesículas sinápticas que funcionam como mecanoreceptores. Estão localizadas no estrato basal e encontradas em grande número na pele glabra das mãos e pés, como também na pele hirsuta e na pele dos lábios e genitais $^{59}$.

$\mathrm{Na}$ epiderme, encontramos os melanócitos que são células dendríticas produtoras de melanina, substância pigmentar produzida apenas na camada basal. A melanina depois de produzida é contida em organelas chamadas melanossomas que são transferidas aos queratinócitos vizinhos. O número de melanócitos é igual em todas as raças e representam mais de $12 \%$ das células da epiderme. O que muda nestas células são a sua forma e atividade (morfologia), tamanho, disposição, o número de melanossomas e fatores determinados geneticamente. A melanina protege a pele da ação dos raios ultravioleta e Ihe confere cor. Além da camada basal os melanócitos se encontram no sistema nervoso central e na retina ${ }^{49}$.

A epiderme é avascular e recebe oxigênio e nutrição por difusão a partir de vasos sanguíneos da derme. É composta por cinco camadas distintas. Da camada mais profunda para superfície temos o estrato germinativo, estrato espinhoso, estrato granuloso, estrato lúcido e estrato córneo (Fig. 2). O estrato lúcido é observado apenas nas regiões palmares e plantares ${ }^{50}$, 


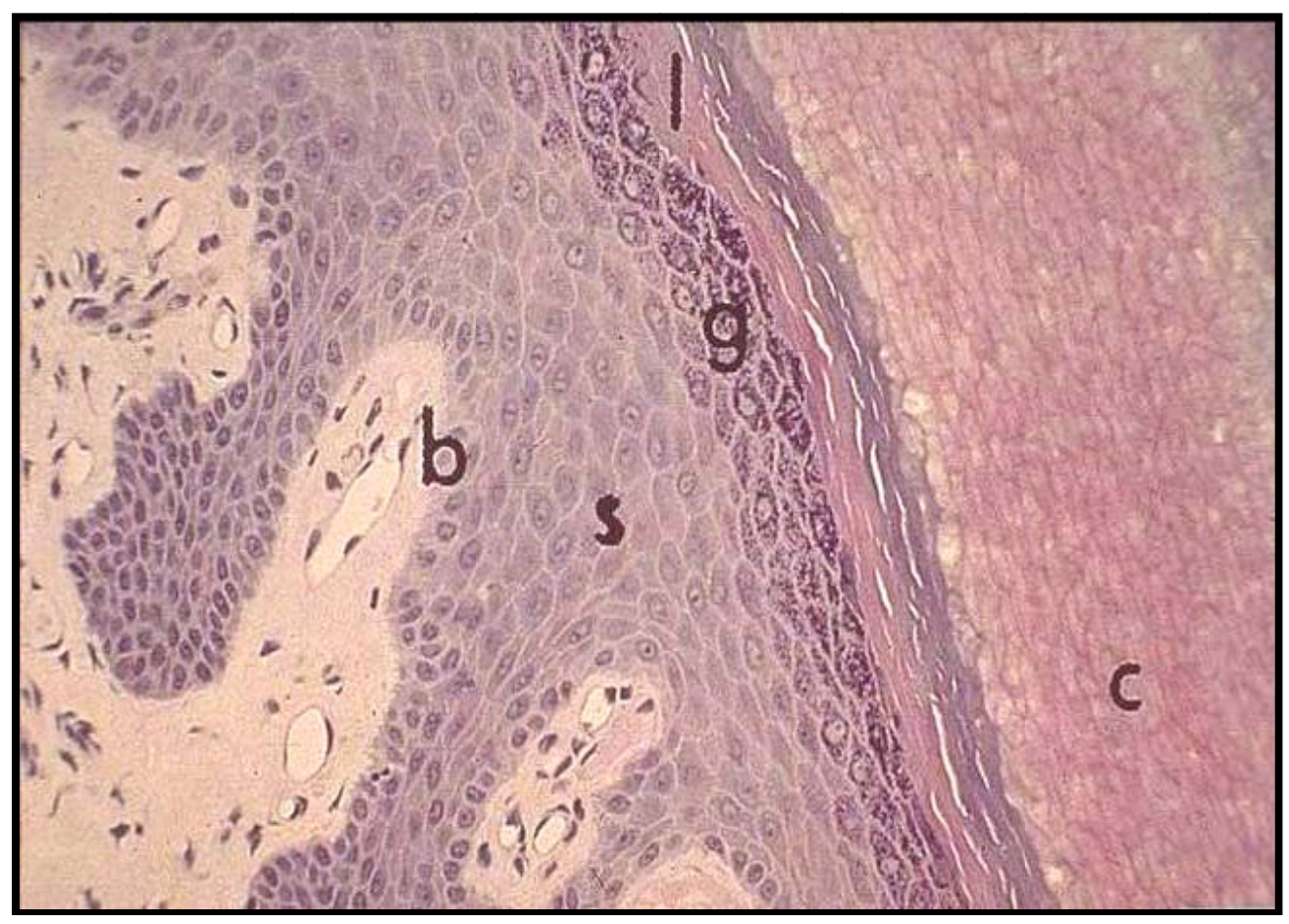

Figura 2. Camadas da epiderme b:estrato germinativo, s:estrato espinhoso, g:estrato granuloso, l:estrato lúcido e c:estrato córneo ${ }^{51}$.

O estrato germinativo, ou camada basal, é o mais profundo e é constituído por células prismáticas ou cúbicas que repousam sobre a membrana basal (MB) ou ZMB, a qual separa a epiderme da derme. São células pouco diferenciadas que apresentam intensa atividade mitótica, dando origem a todas as outras camadas da epiderme. Está em íntimo contato com a derme na forma de uma camada ondulada que se estende ao longo de toda sua superfície. Contém muito pouca queratina. Algumas destas células diferenciam-se e passam para as camadas mais superficiais, enquanto outras permanecem na camada basal e continuam a se dividir ${ }^{55}$.

O estrato espinhoso é formado por células poligonais cúbicas, ou ligeiramente achatadas - células de Malpighi, possui mais queratina que a 
camada basal. As células de Malpighi formam junções celulares agrupadas em feixe, ricas em desmossomos que, ao migrarem para camada espinhosa, tornam-se progressivamente mais achatadas e começam a produzir grânulos intracelulares. Possuem pequenas expansões citoplasmáticas que contêm tonofibrilas as quais proporcionam resistência ao atrito ${ }^{53,55}$.

O estrato granuloso é formado por células achatadas, que possuem grânulos de queratina proeminentes e outros, como substância extracelular, lipídeos e proteínas (colágenos). Estes grânulos se desenvolveram no estrato espinhoso e são eliminados no interior das células do estrato granuloso. Algumas células do extrato granuloso possuem grânulos revestidos por membrana, denominados corpos lamelares, que são constituídos principalmente por lipídeos. A presença de lipídeos nesta camada confere a impermeabilidade da pele ${ }^{55}$.

O estrato lúcido é constituído por uma delgada camada acidófila cujas células não mais possuem organelas e apresentam um núcleo picnótico. São células achatadas hialinas eosinófilas, devido a grânulos protéicos muito numerosos. Não é visível em todas as regiões do corpo e está presente na pele sem folículos pilosos ou pele glabra ${ }^{55}$.

O estrato córneo é a camada mais externa, é constituído por células mortas e achatadas. Não se observa mais nenhuma estrutura ou organela citoplasmática nesta camada. O citoplasma das células desta camada está repleto de queratina ${ }^{55}$. 


\subsubsection{Membrana Basal}

As células mantêm contato entre si através de junções celulares. Também se relacionam por intermédio de uma complexa rede de proteínas e polissacarídeos que preenchem os espaços intercelulares, que constituem a matriz extracelular (MEC). A MEC é responsável, em algumas circunstâncias, pela diversidade morfológica, funcional e patológica dos diversos tecidos ${ }^{58,60}$

Em proporções variáveis a MEC é constituída de um complexo de inúmeras proteínas e polissacarídeos que se organizam, formando uma rede. A MEC forma um substrato que fornece condições adequadas para o crescimento e diferenciação de diversos tipos celulares como, por exemplo, os epitélios que apresentam, na sua superfície com o tecido conjuntivo, uma estrutura chamada de lâmina basal ${ }^{59,61}$.

Em determinadas regiões do organismo como músculos, nervos e vasos sangüíneos, verifica-se, em continuação à lâmina basal, um acúmulo de fibras reticulares e um complexo de proteínas e glicoproteínas, que formam um conjunto visível ao microscópio de luz, conhecido por membrana basal (MB) ou ZMB. A MB compartimentaliza os tecidos, facilita a ancoragem de células adjacentes, age como filtro seletivo, estoca macromoléculas, reveste células nervosas, adiposas e musculares, além de separar células epiteliais do tecido conjuntivo subjacente; é barreira seletiva para células migrantes e neoplásicas e tem papel importante em uma série de doenças infecciosas, dermatológicas e neoplásicas ${ }^{61,96}$. 
Assim sendo, na pele, a ZMB, é uma delgada lâmina de $M E$ que está situada entre a barreira externa da pele, a epiderme, e a barreira interna a derme. A principal função da ZMB é realizar uma aderente junção entre a epiderme e a derme. Doenças hereditárias caracterizadas por mutações genéticas, que resultam em produção defeituosa de proteínas na ZMB, tais como, epidermólise bolhosa distrófica, manifestam-se clinicamente em pele fraca e facilmente susceptível a formação de bolhas, mesmo ao mínimo trauma ${ }^{50,98}$.

Alguns componentes distintos e inter-relacionados da ZMB foram identificados e estudados intensivamente. O interessante é que alguns destes componentes essenciais foram descobertos por serem alvos de reações auto-imunes ${ }^{62,63,98}$.

A membrana basal pode ser formada pela fusão de duas outras lâminas basais adjacentes ou por uma lâmina basal e uma lâmina reticular adjacente ao tecido conjuntivo. A lâmina basal é composta de cinco componentes principais (Figura 3) que são o colágeno tipo IV, laminina, heparansulfato, entactina e fibronectina, enquanto que a lâmina reticular é composta por pequenos feixes de fibras reticulares conhecidas como fibrilas de ancoragem (Figura 4) ${ }^{68,98}$. 


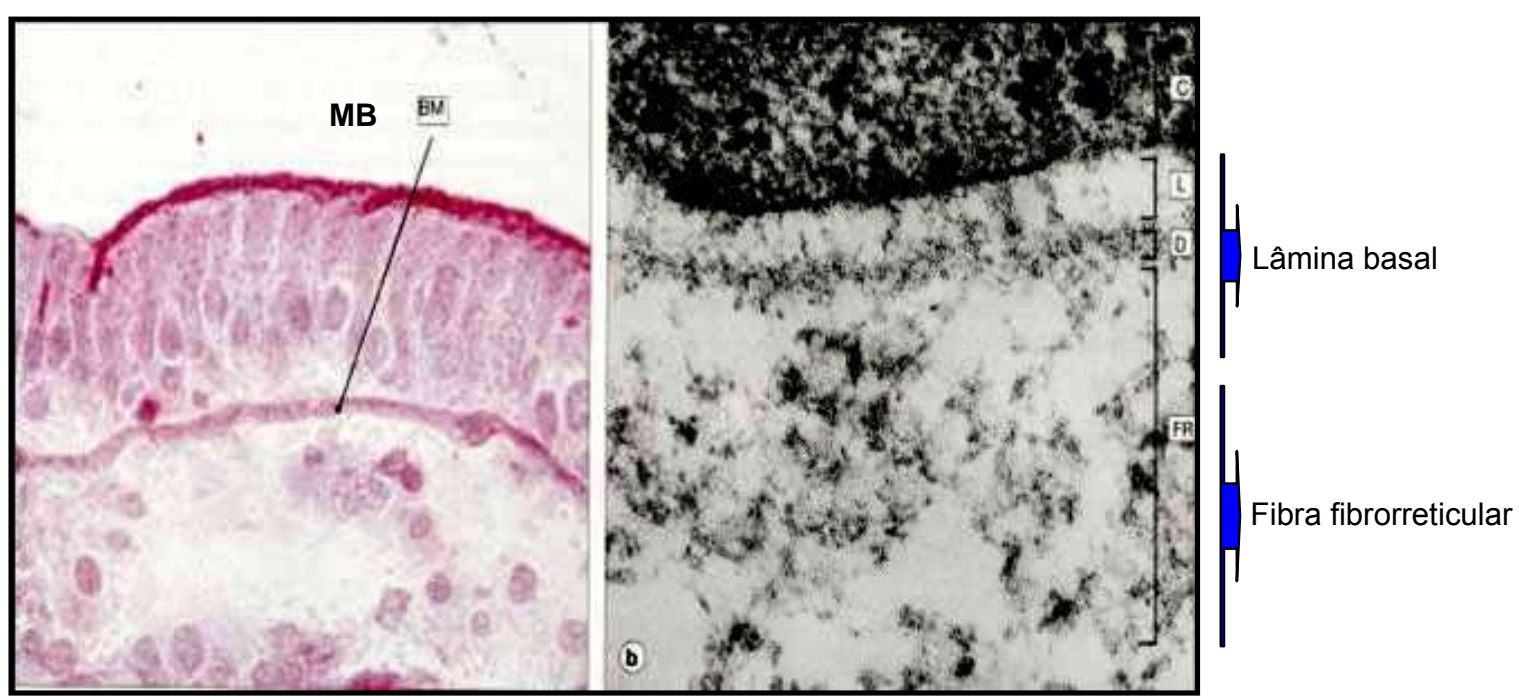

Figura 3. Membrana Basal (MB) ou Zona da Membrana Basal (ZMB), corada por ácido periódico de Schiff (PAS), vista por microscopia óptica e eletrônica (b) ${ }^{51}$

Existem componentes bem caracterizados na ZMB (Figura 4) e estes incluem o antígeno penfigóide (BP230 e BP180), $\alpha_{6} \beta_{4}$ integrina e plectina na camada de hemidesmossomos ou lâmina lúcida superior. Na lâmina lúcida inferior estão localizados a laminina 1, laminina 5, laminina 6, p105 e a entactina ou nidogen ${ }^{63,97}$. O colágeno tipo IV e o perlecan são encontrados na lâmina densa e na sub-lâmina densa o colágeno tipo VII ${ }^{65,71}$. 


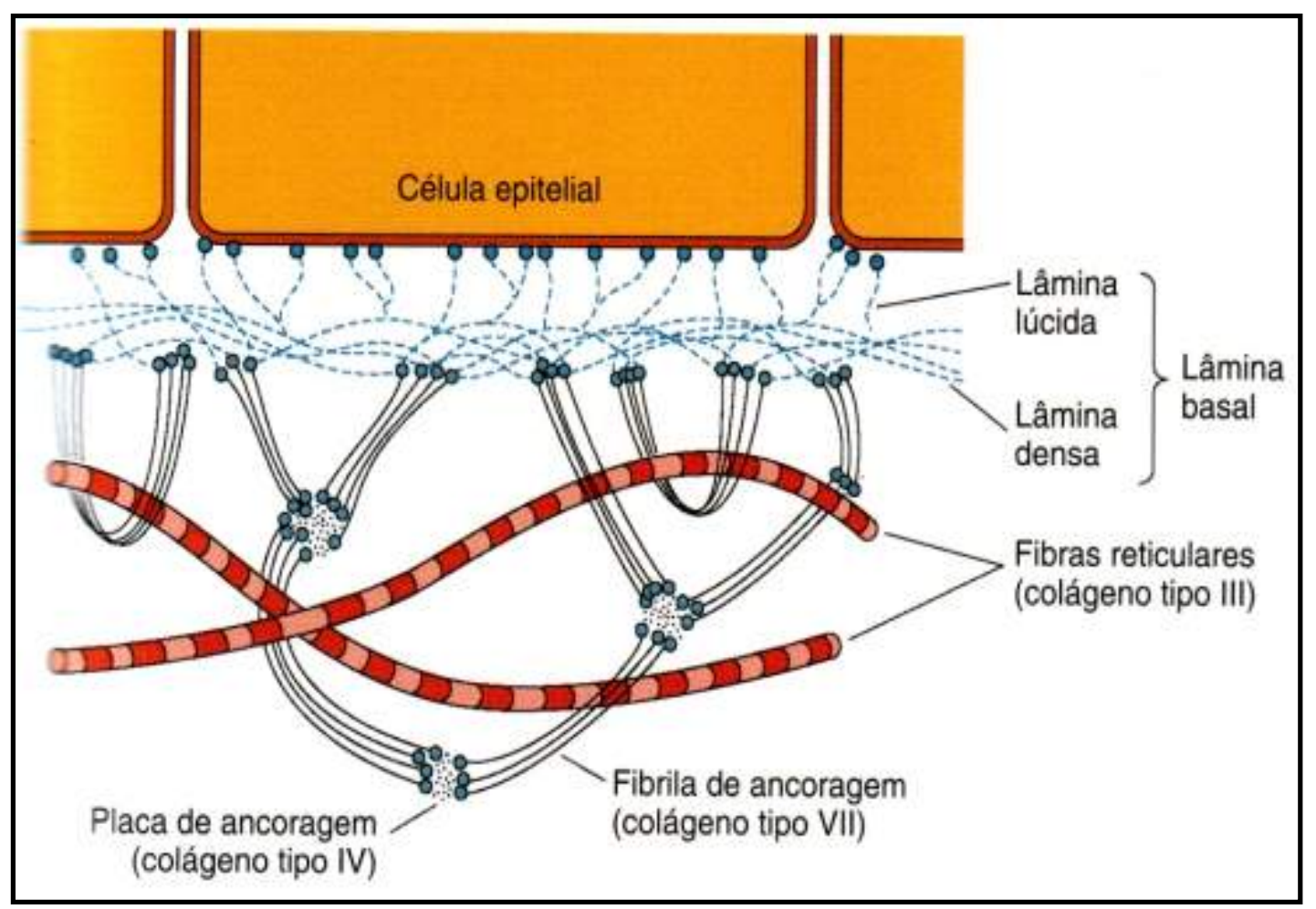

Figura 4. Camadas da Membrana Basal (MB) ou (ZMB): a lâmina basal, as fibras reticulares e as fibrilas de ancoragem ${ }^{64}$

Como resultado de estudos de doenças auto-imunes os componentes essenciais, ou auto-antígenos da membrana basal, envolvidos em reações auto-imunes, foram isolados por técnicas de biologia molecular ${ }^{65}$.

A camada de hemidesmossomos ou lâmina lúcida (também conhecida como lâmina rara) é externa e contém a metade da estrutura de um desmossomo (estrutura observada entre dois queratinócitos adjacentes). É uma placa de ligação intracitoplasmática, de conformação única, na qual o tonofilamento da camada basal se conecta ${ }^{66,68}$.

Situada entre a camada de hemidesmossomos e a lâmina densa está a lâmina lúcida que é eletroluminescente sob a microscopia eletrônica. 
Todavia, finas estruturas filamentosas são observadas e chamadas de filamentos de ancoragem. Esses filamentos se estendem desde os hemidesmossomos dos queratinócitos da camada germinativa, até a lâmina densa, e atravessam a lâmina lúcida. O principal componente desses filamentos é a laminina ${ }^{66,67}$.

A lâmina densa, assim chamada devido a sua aparência densa ao microscópio eletrônico, tem espessura que varia de 35 a $45 \mathrm{~mm}$. Esta estrutura é considerada, para alguns patologistas, ser a verdadeira membrana basal. Os componentes da ZMB nesta área são o colágeno tipo IV, perlecan (heparan sulfato proteoglicano), e talvez a laminina- ${ }^{68,69}$.

Abaixo da lâmina densa há estruturas fibrilares que a conectam com estruturas dérmicas semelhantes a placas. Essas estruturas fibrilares são chamadas de fibrilas de ancoragem. O colágeno tipo VII é o maior componente das fibrilas de ancoragem ${ }^{70}$. O colágeno VII é uma proteína do tipo 290 kDa secretada e sintetizada tanto por queratinócitos como fibroblastos. Essas fibrilas especializadas existem para reforçar a fixação do epitélio exterior da membrana basal aos tecidos conjuntivos subjacentes 71,72. Sua importância pode ser inferida pela instabilidade da membrana basal observada em pacientes com epidermólise bolhosa distrófica, patologia frequentemente associada a mutações do gene do colágeno $\mathrm{VII}^{74}$.

A incorporação de colágeno VII às fibrilas de ancoragem é, provavelmente, pré-requisito para a síntese de membrana basal estável e sua falha se manifesta clinicamente por fragilidade da pele e formação de vesículas subepidérmicas em zonas da pele sujeitas a trauma (Figura 5) ${ }^{75,76,77 .}$ 


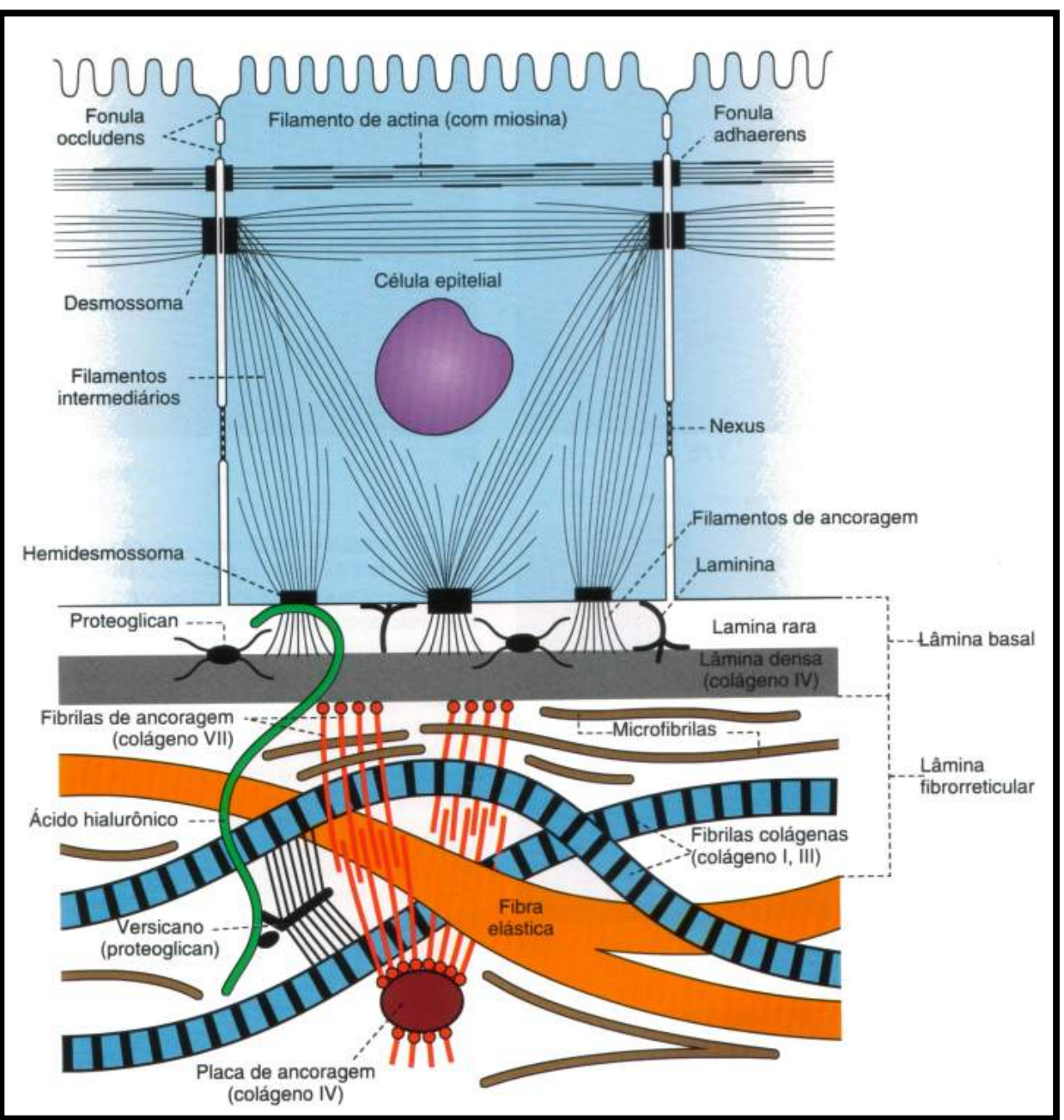

Figura 5. A membrana basal, suas camadas e seus ligamentos: na epiderme, camada germinativa por meio dos hemidesmossomos, e filamentos de ancoragem; na derme por meio das fibrilas de ancoragem ${ }^{64}$

\subsubsection{Derme}

A derme apresenta uma organização complexa. É formada basicamente por denso estroma fibroelástico de tecido conjuntivo, que encerra extensas redes vasculares e terminações nervosas sensíveis à temperatura, pressão e dor, bem como glândulas e anexos que derivam da 
epiderme. Apresenta uma variação considerável de espessura nas diferentes partes do organismo que em média é de aproximadamente dois milímetros, podendo chegar a $4 \mathrm{~mm}^{78}$.

A existência da derme é fundamental para a epiderme pois, confere a esta última, flexibilidade e nutrientes carreados por meio da irrigação sanguínea. É rica em fibras colágenas e elásticas que proporcionam à pele a capacidade de distender-se. Numerosos feixes de fibras colágenas, acompanhadas de fibras de elastina, encontram-se imersos em substância amorfa, constituída por principalmente por glicosaminoglicanos - GAG. Estas três estruturas formam o tecido conjuntivo dérmico, que tem a sua origem na atividade metabólica do fibroblasto, principal célula do tecido conjuntivo. Os fibrócitos também são células importantes na estrutura da derme onde também são encontrados basófilos, histióciótos e plasmócitos ${ }^{79}$.

A substância amorfa, ou matriz extracelular (MEC), também conhecida como substância intercelular, substância fundamental ou substância homogênea da derme, é um complexo molecular que constitui um veículo para passagem de células, moléculas hidrossolúveis e íons diversos e é uma barreira à penetração de microorganismos. Além dos glicosaminoglicanos (GAGs), fibras colágenas e elastinas a MEC é formada por proteoglicanos (PGs) e glicoproteínas adesivas (integrinas, lamininas e fibronectinas) ${ }^{79,80}$.

Os fibroblastos originam-se de células mesenquimatosas indiferenciadas. À microscopia óptica, os fibroblastos apresentam prolongamentos citoplasmáticos irregulares, núcleo eucromático de forma 
ovóide e núcleo evidente. À microscopia eletrônica nota-se grande quantidade de retículo endoplasmático rugoso e a presença do complexo de Golgi, devido à grande produção protéica destinada a síntese de componentes da matriz extracelular como fibras colágenas e elásticas, proteoglicanos e glicosaminoglicanos ${ }^{80,81}$.

A derme é o tecido conjuntivo onde a epiderme se apóia e fica aderida ao tecido celular subcutâneo. Sua superfície é irregular onde se observam saliências que acompanham reentrâncias correspondentes na epiderme conhecidas como papilas dérmicas. As papilas dérmicas aumentam a área de contato da derme com a epiderme e reforçam a união entre essas duas camadas. São mais frequentes nas zonas sujeitas a pressões e atritos ${ }^{79}$.

A derme é constituída por duas camadas, de limites pouco distintos: a papilar (superficial), e a reticular (mais profunda). A camada papilar é delgada, constituída por tecido conjuntivo frouxo que forma as papilas dérmicas. Nesta camada são encontradas fibrilas especiais de colágeno, que se inserem por um lado, na membrana basal e, por outro, penetram profundamente na derme. Essas fibrilas contribuem para realizar a adesão da derme à epiderme. A camada reticular é mais espessa, constituída por tecido conjuntivo denso. A grande maioria das fibras dérmicas é composta por colágeno, principalmente o do tipo I e III, responsáveis pelo mecanismo de resistência da pele ${ }^{78}$.

A arquitetura dos vasos sanguíneos da derme é muito complexa. Originadas das grandes artérias, surgem artérias perfurantes entre as aponeuroses que se ramificam de forma horizontal na derme superficial. $O$ 
retorno venoso se dá através dos capilares por três redes venosas consecutivas: o plexo venoso subpapilar, a rede venosa da derme e, por último, a rede venosa que se localiza na camada limítrofe entre a derme e o tecido celular subcutâneo ${ }^{80}$.

Os vasos linfáticos da pele são revestidos por uma única camada de células endoteliais. Esse sistema encontra-se na porção superior da derme. Os vasos linfáticos originam-se em fundo saco, formando depois a rede linfática subpapilar que se dirige ao tecido celular subcutâneo ${ }^{80}$.

Além dos vasos sanguíneos e linfáticos, e dos nervos, também, são encontrados na derme as seguintes estruturas, derivadas da epiderme: folículos pilosos, glândulas sebáceas e glândulas sudoríparas ${ }^{80}$.

As terminações nervosas são provenientes das fibras sensitivas do sistema nervoso cérebro-espinhal e do sistema nervoso autônomo. Essas terminações nervosas podem ser livres ou conjugadas a receptores em forma de corpúsculos, como os de Vater-Pacini e de Krause, sensíveis à pressão e ao frio respectivamente ${ }^{78}$.

O fibrócito, ou fibroblasto quiescente, perde seus prolongamentos citoplasmáticos assumindo características fusiformes. Na cicatrização, o fibrócito pode voltar a sintetizar MEC, reassumindo a estrutura de fibroblasto. Fibroblastos que participam ativamente do processo de cicatrização das feridas, e possuem altos teores de actina e miosina, são chamados de miofibroblastos ${ }^{82}$.

O principal componente da derme é o colágeno produzido pelos fibroblastos. O colágeno é a proteína mais abundante do corpo humano 
representando $30 \%$ do total das proteínas existentes. As fibras colágenas, compostas de glicina, prolina e hidroxiprolina são mais frequentes no tecido conjuntivo e, aproximadamente $75 \%$ destes têm cor branca, o que confere essa cor aos tecidos aos quais são predominantes, como por exemplo, os tendões $^{80}$.

\subsection{Funções da pele}

Graças à arquitetura e às propriedades físicas químicas e biológicas de suas várias estruturas, a pele, como membrana envolvente e isolante, é um órgão capacitado à execução de múltiplas funções ${ }^{78}$.

Proteção: constitui a barreira de proteção para as estruturas internas do organismo à ação de agentes externos de qualquer natureza e, ao mesmo tempo, impede perdas de água, eletrólitos e outras substâncias do meio interno ${ }^{79}$.

Proteção imunológica: a pele, graças aos seus componentes dérmicos que participam do sistema retículo endoplasmático, é um órgão de grande atividade imunológica, onde atuam intensamente os componentes de imunidade humoral e celular, motivo pelo qual, hoje, grande quantidade de testes imunológicos, bem como práticas imunoterápicas, são estudados na pele ${ }^{79}$.

Termorregulação: graças à sudorese, constrição e dilatação da rede vascular cutânea, a pele processa o controle homeostático da temperatura $\operatorname{orgânica~}^{79}$. 
Percepção: através da complexa e especializada rede nervosa cutânea, a pele é o órgão receptor do calor, frio, dor e tato ${ }^{79}$.

Secreção: A secreção sebácea é importante para a manutenção eutrófica da própria pele, particularmente da camada córnea, evitando a perda de água. Além disso, o sebo um tem propriedades antimicrobianas e contém substâncias precursoras da vitamina D. Quanto às glândulas sudoríparas, a eliminação de restos metabólicos não tem valor como função excretora $^{79}$.

\subsection{Ciclo celular da pele}

Durante toda a vida a pele segue seu ciclo celular de crescimento e é renovada continuamente ${ }^{83}$. Novas células produzidas por mitoses no estrato germinativo exercem uma pressão que impulsionam as células para a superfície. Ao mesmo tempo em que cada célula vai sendo empurrada para a superfície, sofre transformações: achata-se, ancora-se às vizinhas, secreta substâncias fosfolipídicas (que se depositam entre as células, contribuindo para a vedação), produzem queratina e terminam por perder o núcleo para tornarem-se placas superficiais e descamarem. A queratina produzida pode ser macia, como na pele, ou dura como nas unhas e cabelos. Calcula-se que o tempo de renovação da camada Malpighiana é de 19 dias e a migração das células aí produzidas até a superfície de 10 dias ${ }^{84}$. 


\subsection{Vesículas}

Define-se vesícula como uma elevada lesão que contém líquido claro; uma bolha pequena com menos de $10 \mathrm{~mm}$ de diâmetro ${ }^{85}$.

Define-se bolha como uma elevada lesão que contém líquido claro; uma vesícula grande com diâmetro de $10 \mathrm{~mm}$ ou mais ${ }^{85}$.

O presente estudo pesquisa o surgimento de vesículas, ou bolhas em "enxertos de pele". A gênese dessas vesículas em algumas doenças de pele está relacionada a alterações a ZMB, que devido a defeitos na sua estrutura causa o surgimento de vesículas ${ }^{77}$.

Uma das evidências que mostram o surgimento de vesículas em doenças da pele é observada em algumas doenças hereditárias caracterizadas pela produção de proteínas defeituosas. Essa produção defeituosa é secundária à mutação de genes codificados por proteínas da membrana basal. A epidermólise bolhosa é caracterizada por defeito na produção de laminina-5, BP180, e integrina. Manifesta-se clinicamente por fragilidade da pele e formação de vesículas subepidérmicas (Figura 6) em zonas da pele sujeitas a trauma ${ }^{77}$. 


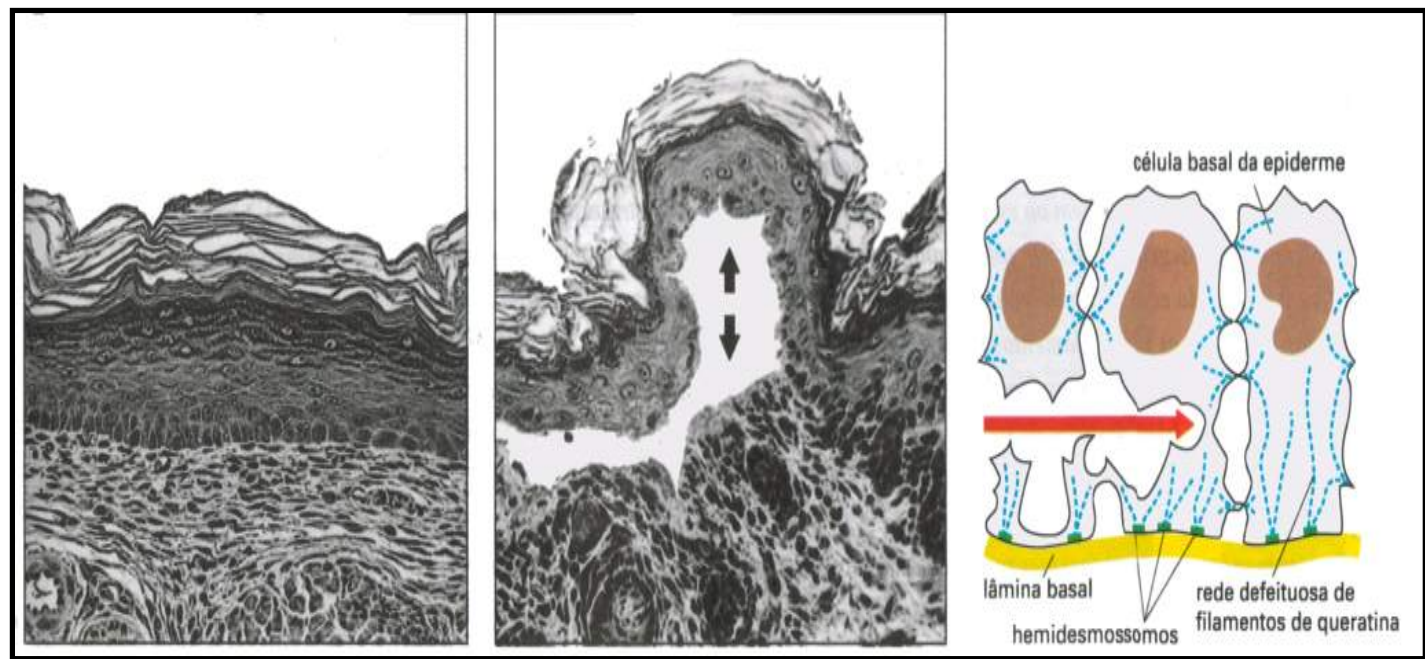

Figura 6. Sequência da formação de vesículas e ilustração, na epidermólise bolhosa distrófica onde há alteração na estrutura Transição dermoepidérmica $^{58}$

A literatura é escassa em pesquisas sobre o surgimento de vesículas em "enxertos de pele". Os poucos artigos existentes criam dúvidas quanto à nomenclatura do que é área enxertada e enxerto de pele. Com a finalidade de estudar essas referências literárias, Gomez, em 2005, publicou trabalho sobre formação de vesículas em tegumentos neoformados ${ }^{16}$. Nesse trabalho há referências dos casos de vesículas em áreas de enxerto de pele, áreas doadoras, e áreas de queimaduras curadas (Tabela 2). 
Tabela 2. Revisão literária realizada por Gomez em 2005

\begin{tabular}{|c|c|c|c|c|c|c|}
\hline \multicolumn{7}{|c|}{ NEORFORMED INTEGUMENT TYPES ACCORDIND TO THE LITERATURE } \\
\hline \multicolumn{2}{|l|}{ LITERATURE } & \multirow[t]{3}{*}{ No OF PATIENTS } & \multicolumn{3}{|c|}{ BLISTER CASES } & $\mathrm{N}^{\circ}$ OF CASES \\
\hline \multirow[t]{2}{*}{ AUTHORS } & \multirow[t]{2}{*}{ YEAR } & & \multicolumn{4}{|c|}{ Integuments according to the literature } \\
\hline & & & Healed burn site & Donor sites & Grafted sites & \\
\hline Barker and Coterill & 1980 & 1 & - & 1 & - & 1 \\
\hline Berman & 1982 & 1 & - & 1 & - & 1 \\
\hline Baran and Juhlin & 1984 & 8 & - & 2 & 6 & 8 \\
\hline Pedragosa et al & 1986 & 1 & 1 & - & - & 1 \\
\hline Epstein et al & 1988 & 1 & - & - & 1 & 1 \\
\hline Woodeley et al & 1988 & 4 & - & 4 & $3^{a}$ & 3 \\
\hline Chetty et al & 1992 & 13 & 2 & 7 & 8 & 17 \\
\hline \multirow[t]{2}{*}{ Bergaman } & 1997 & 2 & - & 1 & 1 & 2 \\
\hline & & 31 & $3-9 \%$ & $12-35 \%$ & $19-56 \%$ & $34-100 \%$ \\
\hline
\end{tabular}

Gomez, Mariani e Ferreira. The problem of subepidermal blisters in neoformed integuments. Burns 31 (2005) 811-81 ${ }^{\mathrm{a}}$ cultured epidermis

\subsection{Enxertia de pele}

Sem dúvida alguma o tratamento cirúrgico é uma das etapas mais importantes do processo de cura do paciente queimado, pois ele será o responsável em devolver-Ihe o revestimento cutâneo perdido em decorrência do trauma. Atualmente, essa etapa deve ser realizada o mais precocemente possível, impedindo assim que os efeitos secundários da perda da pele se prolonguem e comprometam o estado geral do paciente ${ }^{86}$. 
O principal objetivo do tratamento cirúrgico das queimaduras profundas é a remoção precoce do tecido desvitalizado e a imediata cobertura da área ulcerada ${ }^{86}$.

Com a finalidade de se proceder ao tratamento cirúrgico, deve-se primeiramente considerar quando é que uma queimadura tem indicação de ser operada. Fundamentalmente, operam-se as queimaduras profundas. As superficiais não exigem operações uma vez que, se não houver complicações associadas, a evolução será a cura espontânea com bons resultados. Essa cura pode ocorrer por regeneração, nos casos das queimaduras de primeiro grau; ou por restauração, nos casos das queimaduras de segundo grau, não profundas, sem que fiquem sequelas funcionais, ou estéticas importantes. Sendo a queimadura de segundo grau profundo ou de terceiro grau, a não operação acarretará uma evolução indesejável, com hipertrofia cicatricial associada às consequências funcionais e estéticas inerentes, no primeiro caso e, além disto, com cicatrizes deformantes e revestimento epitelial de péssima qualidade no segundo caso ${ }^{86}$.

Para se evitar esses problemas, é necessário que se faça a enxertia de pele nessas áreas e, para tanto, é necessário realizar antes a ressecção dos tecidos desvitalizados, escaras, preparando assim o leito receptor viável que integrará o enxerto a ser colocado. É consenso mundial, atualmente, que o maior benefício para o doente será obtido quando se fizer essa operação precocemente, diminuindo assim não só a espoliação pela área queimada, como também a possibilidade de infecção, e o período de 
internação. Com isto se reduz os custos do tratamento e minimiza-se as possíveis sequelas decorrentes ${ }^{87}$.

Os enxertos podem ser divididos segundo algumas características:

A - Quanto à origem:

- Auto-enxertos ou isoenxertos: quando excisados do próprio receptor ou de gêmeo univitelínico - constituem tratamento definitivo, fechando o meio interno e não sofrendo rejeição.

- Homoenxertos ou aloenxertos: quando excisados de outros indivíduos da mesma espécie - em geral, são curativos biológicos temporários que vão preparar melhor o leito receptor para a autoenxertia. Se estiverem sem células vivas (como os preservados em glicerol ou a matriz dérmica acelular), podem se revascularizar e permanecer definitivamente no local, mas exigem sobre eles outra enxertia epitelial (epidérmica ou dermoepidérmica) a fim de vedarem o meio interno.

- Heteroenxertos ou xenoenxertos: quando oriundos de seres de espécies diferentes da do receptor - funcionam exclusivamente como curativos biológicos temporários.

B - Quanto ao formato:

- Laminados: são os melhores, tanto do ponto de vista estético quanto funcional; o fragmento de pele, da forma como foi retirado, é colocado na área receptora. 
- Malhas: em geral, utilizadas nos grandes queimados, com escassez de áreas doadoras onde, após a retirada do enxerto, este é processado num dermátomo específico (expansor de pele) que abre a lâmina excisada como uma "rede de pesca", propiciando assim um ganho de superfície corpórea enxertada.

- Selos: de conotação histórica, não mais são utilizados hoje em dia, tendo sido substituídos pelas malhas.

C - Quanto à espessura:

- Espessura total: levam toda a derme da área doadora, além da epiderme. Preservam anexos como glândulas sebáceas, sudoríparas e alguns folículos pilosos, e dão melhor resultado estético e funcional. A área doadora equivale a uma queimadura de terceiro grau e necessita ser fechada primariamente ou com um enxerto de espessura parcial.

- Espessura Parcial: finos, médios ou grossos, dependendo da porcentagem da derme da área doadora incluída nos mesmos, além da epiderme. O resultado final será tanto melhor, em geral, quanto mais espesso for. Os enxertos de espessura total têm a integração mais difícil pela maior quantidade de tecido a ser nutrido pela área receptora. 
A escolha das áreas doadoras determinará resultados mais favoráveis ou não, em função de certos aspectos, tanto no tocante à estética quanto à função. De maneira geral, áreas simétricas ou, na impossibilidade destas, a maior proximidade entre as áreas doadoras e as receptoras do enxerto oferecem maiores semelhanças entre essas peles, contribuindo para o melhor resultado final ${ }^{86}$.

\subsection{Image J}

Image J, software escolhido para este estudo, é um programa de domínio público desenhado para processamento e análises de imagens. $O$ programa foi desenvolvido inicialmente para uso em Macintosh. Como é programado em Java, pode funcionar como um software aplicativo, ou seja, pode ser executado no contexto de outro programa, como o Windows, Mac OS, Mac OS X e Linux ${ }^{88}$.

O programa pode exibir, editar, analisar, processar, armazenar e imprimir imagens de 8, 16 e 32 bits desde que estejam no formato TIFF, GIF, JPEG, BMP, DICOM, STIF ou RAW. Calcula distâncias e ângulos, criando diagramas de densidade, manipulando contraste, nitidez e filtros, entre outros atributos ${ }^{89}$. Existem vários softwares disponíveis no mercado para análise de imagens, porém, em geral, eles são muito caros e sua utilização muito complexa, muitas vezes necessitando de treinamento específico. Por isto é interessante o uso de um software livre que acompanhe um manual de 
auxílio ao usuário e o estabelecimento de rotinas de análises que atendam às necessidades dos diversos grupos de pesquisa e sigam as normas técnicas internacionais, desde que suas análises sejam devidamente validadas e certificadas pelas normas existentes.

Dois softwares de análise e processamento de imagens foram estudados para a realização deste trabalho o Image Tool e o Image J. Além dos softwares possuírem código-fonte livre, existe, em ambos, a possibilidade de desenvolvimento de "plugins" que se adeqüam às necessidades dos usuários (Figura 7) ${ }^{90}$. 


\begin{tabular}{|c|c|c|}
\hline & \multicolumn{2}{|l|}{ Softwares } \\
\hline Característica & Image Tool & Image $\mathrm{J}$ \\
\hline $\begin{array}{l}\text { Linguagem em que foi } \\
\text { Desenvolvida }\end{array}$ & Borland $\mathrm{C}++$ & Java \\
\hline Requerimentos do Sistema & $\begin{array}{l}\text { - Windows } 95 \text { ou mais } \\
\text { recente; } \\
\text { - } 16 \mathrm{MB} \text { de memória RAM } \\
\text { no mínimo, embora o } \\
\text { recomendável seja } 32 \mathrm{MB} \text {. }\end{array}$ & $\begin{array}{l}\text { - Windows } 95 \text { ou mais recente, } \\
\text { Mac OS, Mac OS } \\
\text { X e Linux; } \\
\text { - } 64 \text { MB de memória RAM, no } \\
\text { mínimo, embora o } \\
\text { recomendável seja } 256 \text { MB. }\end{array}$ \\
\hline Extensões Suportadas & $\begin{array}{l}\text { - PCX (Paint Brush), } \\
\text { - BMP (Windows Bitmap) } \\
\text { - TIF/TIFF (Tagged Image } \\
\text { Format ) } \\
\text { - PNG (Portable Network } \\
\text { Graphics) } \\
\text { - PCT (Macintosh PICT) } \\
\text { - JPG/JPEG (JointPhotographic } \\
\text { Engineers Group) } \\
\text { - ITS (Image Tool Stack } \\
\text { Format) }\end{array}$ & $\begin{array}{l}\text { - TIF/TIFF (Tagged Image } \\
\text { Format ) } \\
\text { - BMP (Windows Bitmap) } \\
\text { - JPG/JPEG (Joint Photographic } \\
\text { Engineers } \\
\text { Group) } \\
\text { - PGM (Portable Grey Map) } \\
\text { - DICOM (Digital Imaging } \\
\text { and Communications in } \\
\text { Medicine) } \\
\text { - FITS (Flexible Image } \\
\text { Transport System) } \\
\text { - NIH (Macintosh Image Format) }\end{array}$ \\
\hline $\begin{array}{l}\text { Linguagem de Script } \\
\text { (Macros) }\end{array}$ & $\begin{array}{l}\text { - Permite a compilação de } \\
\text { macros, com extensão DLL, em } \\
\text { qualquer linguagem de } \\
\text { softwareção; } \\
\text { - Possui comandos próprios } \\
\text { que utilizam funções do próprio } \\
\text { software; } \\
\text { - Permite que o plugin } \\
\text { desenvolvido seja alocado no } \\
\text { menu conveniente. }\end{array}$ & $\begin{array}{l}\text { - As macros devem ser } \\
\text { realizadas em linguagem } \\
\text { JAVA; } \\
\text { - Possui comandos próprios } \\
\text { que utilizam funções do próprio } \\
\text { software; } \\
\text { - Permite que o plugin } \\
\text { desenvolvido seja alocado no } \\
\text { menu conveniente }\end{array}$ \\
\hline
\end{tabular}

Figura 7. Quadro comparativo do Image Tool com o Image J 
Figura 7. - conclusão

\begin{tabular}{|c|c|c|}
\hline Filtros e Operações & $\begin{array}{l}\text { - Conta com as operações e } \\
\text { filtros mais básicos para } \\
\text { processamento e análise } \\
\text { de imagens. }\end{array}$ & $\begin{array}{l}\text { - Possui grande quantidade } \\
\text { de filtros e operações para } \\
\text { processamento e análise de } \\
\text { imagens, permitindo o } \\
\text { download e instalação de } \\
\text { filtros desenvolvidos por } \\
\text { outros usuários participantes de } \\
\text { fóruns do software; } \\
\text { - Possui um comando que } \\
\text { permite salvar um arquivo } \\
\text { de imagem em um arquivo } \\
\text { de texto (formato TXT), } \\
\text { com coordenadas e intensidade } \\
\text { de cada pixel } \\
\text { da imagem que não seja do } \\
\text { background. }\end{array}$ \\
\hline Ajuda ao usuário & $\begin{array}{l}\text { - Possui documentação de } \\
\text { ajuda }\end{array}$ & $\begin{array}{l}\text { - Possui documentação de } \\
\text { Ajuda } \\
\text { - Possui grande número de } \\
\text { fóruns de ajuda online }\end{array}$ \\
\hline $\begin{array}{l}\text { Plugins de Análise de } \\
\text { Imagem }\end{array}$ & $\begin{array}{l}\text { - A máscara da imagem ao } \\
\text { ser analisada é feita na imagem } \\
\text { corrente, não podendo ser } \\
\text { salva; } \\
\text { - Permite que a janela } \\
\text { contendo os resultados sejam } \\
\text { exportados para um arquivo } \\
\text { DAT; } \\
\text { - Representa graficamente o } \\
\text { perfil de níveis de cinza de uma } \\
\text { linha desenhada na imagem. }\end{array}$ & $\begin{array}{l}\text { - Permite salvar a máscara } \\
\text { da imagem analisada, ou } \\
\text { seja, além da imagem original, } \\
\text { cria uma segunda } \\
\text { imagem com os números } \\
\text { atribuídos pela contagem } \\
\text { de pixels que pode ser salva; } \\
\text { - Permite que a janela } \\
\text { contendo os resultados (área, } \\
\text { perímetro, comprimento, etc.) } \\
\text { sejam exportados para um } \\
\text { arquivo com formato XLS } \\
\text { (Microsoft Excel); } \\
\text { - Além de representar } \\
\text { graficamente o perfil de } \\
\text { níveis de cinza para uma } \\
\text { linha traçada na imagem, } \\
\text { pode fazer a representação } \\
\text { de toda a superfície da imagem } \\
\text { em questão (surface plot). } \\
\text { - Permite a colocação de } \\
\text { uma barra de escala dos } \\
\text { níveis de cinza da imagem. }\end{array}$ \\
\hline
\end{tabular}

Figura 7. Conclusão do quadro comparativo do Image Tool com o Image J 
4 MÉTODOS 
Este trabalho foi aprovado pela Comissão de Ética para Análise de Projetos de Pesquisa do Hospital das Clínicas da Faculdade de Medicina da Universidade de São Paulo (CAPPesq - HCFMUSP), sob o protocolo de pesquisa número 0276/07 (Anexo A), e resultou na pesquisa conjunta entre a Divisão de Cirurgia Plástica e Queimaduras do Hospital das Clínicas da Faculdade de Medicina da Universidade de São Paulo (HCFMUSP) e o Laboratório de Dermatopatologia da Divisão de Dermatologia do Hospital das Clínicas da Faculdade de Medicina da Universidade de São Paulo (HCFMUSP).

Todos os pacientes deste estudo receberam carta de informação em linguagem simples e clara (Anexo B) e assinaram o Termo de Consentimento Informado Livre e Esclarecido (Anexo C).

\subsection{Casuística}

Foram estudados, no período de 31 de agosto de 2007 a 31 de maio de 2008, 23 pacientes de enxertia de pele na Divisão de Queimaduras do HC-FMUSP, onde foi considerada a ausência de risco para os pacientes.

Epidemiologicamente, este é um estudo de caso-controle do tipo observacional prospectivo ${ }^{91}$. 
Os 23 pacientes eram portadores de médias e grandes queimaduras, com lesões de terceiro grau, onde, para a cura das queimaduras, foi indicada a enxertia de pele.

A faixa etária foi de 20 a 60 anos, sendo que 19 pacientes do sexo masculino e 06 pacientes do sexo feminino foram estudados. Pacientes portadores de qualquer comorbidade foram excluídos do estudo (Tabela 3). Pela dificuldade de compreensão do estudo e, também, por ser necessária a permisão dos pais ou responsáveis, as crianças e adolescentes foram excluídos da pequisa.

O estudo foi realizado com enxertias de pele de espessura parcial para a cura das úlceras pós-queimaduras, conforme a rotina da Divisão de Queimaduras do HCFMUSP.

Para a excisão da pele foi utilizado o dermátomo elétrico marca Zimmer. A graduação da abertura da lâmina para a retirada do enxerto foi de $0,11 \mathrm{~mm}$ para todos os casos (Figura 8).

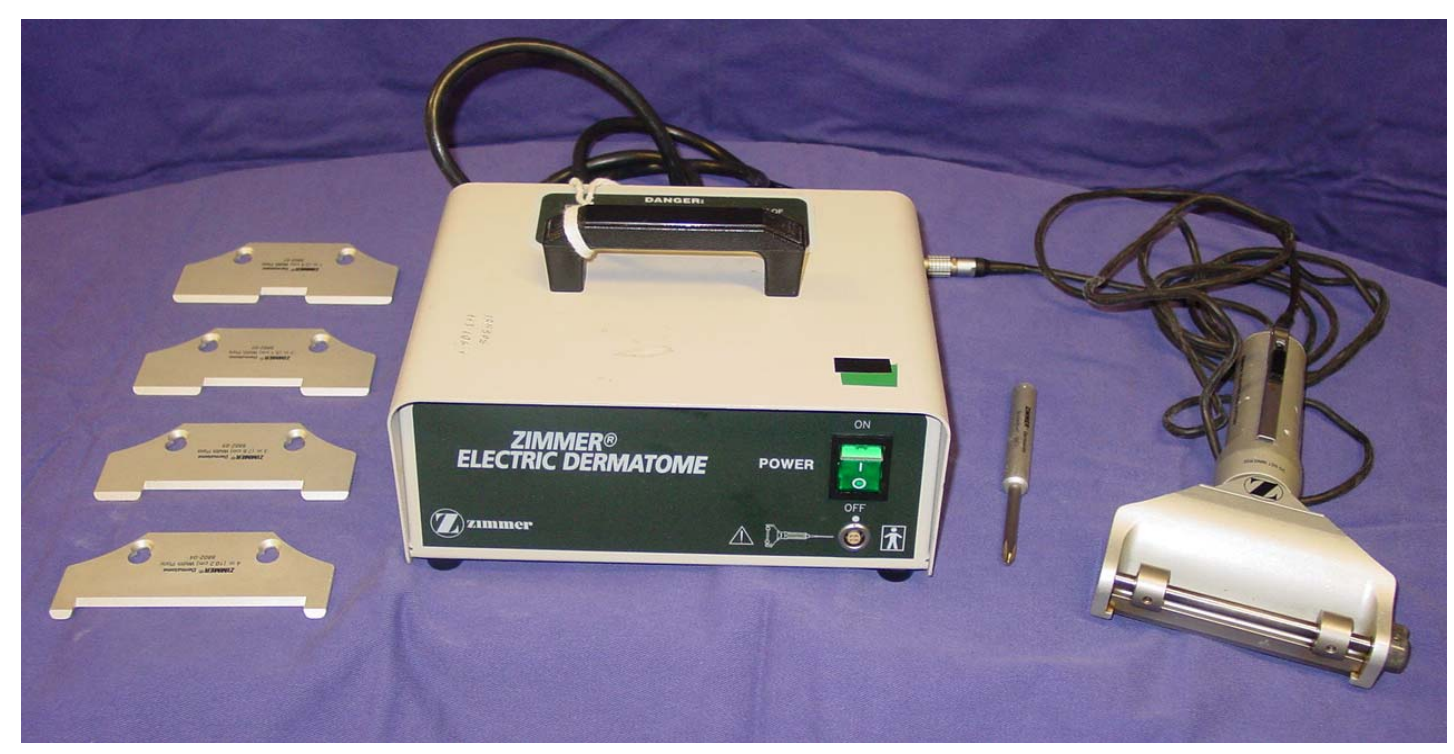

Figura 8. Dermátomo elétrico 
As áreas doadoras foram escolhidas de acordo com planejamento cirúrgico prévio onde foram avaliados critérios estéticos e de melhor área para cada caso.

\subsection{Biópsias}

Nos 23 pacientes estudados realizaram-se duas biópsias: a primeira, imediatamente antes da excisão do enxerto, na área doadora - pele sã, com vazador de $0,5 \mathrm{~mm}$. Esta amostra de pele foi considerada como amostra padrão normal da transição dermoepidérmica - Amostra PADRÃO - AD (área doadora).

Colocado e enxerto na área receptora um ponto de fio mono-nylon 5-0 foi dado no orifício da biópsia a fim de demarcar o local. Após a integração do enxerto, com 10 dias, realizou-se uma segunda biópsia, com o mesmo vazador, próxima à área da primeira biópsia, marcado pelo ponto de mononylon 5-0, - Amostra TESTE - ENX (enxerto). A segunda biópsia foi realizada entre o $10^{\circ}$ e $12^{\circ}$ pós-operatório, de acordo com a Tabela 3. 
Tabela 3. Casuística contendo idade, sexo, tempo decorrido para a segunda biópsia (PO), área doadora e área enxertada

\begin{tabular}{|c|c|c|c|c|c|}
\hline Pacientes & IDADE & SEXO & PO & $A D$ & $\mathrm{AE}$ \\
\hline 1 & 76 & M & $11^{\circ}$ & coxa dir & m. inf.dir \\
\hline 2 & 30 & $M$ & $13^{\circ}$ & m.inf. dir & região cervical \\
\hline 3 & 30 & M & $15^{\circ}$ & dorso & antebraço esq \\
\hline 4 & 41 & $M$ & $10^{\circ}$ & coxa dir & coxa dir \\
\hline 5 & 46 & M & $14^{\circ}$ & abdome & m. inf. dir \\
\hline 6 & 53 & $M$ & $13^{\circ}$ & coxa esq & m. inf. dir \\
\hline 7 & 38 & M & $10^{\circ}$ & coxa dir & m. inf. esq \\
\hline 8 & 53 & $\mathrm{~F}$ & $12^{\circ}$ & coxa dir & abdome \\
\hline 9 & 26 & M & $10^{\circ}$ & coxa dir & pescoço \\
\hline 10 & 52 & $\mathrm{~F}$ & $10^{\circ}$ & coxa dir & m. inf. esq \\
\hline 11 & 47 & $\mathrm{~F}$ & $10^{\circ}$ & glúteo esq & glúteo esq \\
\hline 12 & 30 & $\mathrm{~F}$ & $11^{\circ}$ & coxa dir & abdome \\
\hline 13 & 53 & M & $10^{\circ}$ & m.inf. esq & m. inf. esq \\
\hline 14 & 33 & $\mathrm{~F}$ & $11^{\circ}$ & coxa dir & m. inf. dir \\
\hline 15 & 19 & $M$ & $12^{\circ}$ & coxa dir & m. superior dir \\
\hline 16 & 25 & M & $11^{\circ}$ & coxa dir & braço dir \\
\hline 17 & 32 & M & $11^{\circ}$ & coxa dir & coxa dir \\
\hline 18 & 33 & M & $10^{\circ}$ & coxa dir & braço dir \\
\hline 19 & 55 & M & $10^{\circ}$ & braço dir & braço dir \\
\hline 20 & 20 & $\mathrm{~F}$ & $13^{\circ}$ & coxa dir & m. inf. dir \\
\hline 21 & 55 & M & $13^{\circ}$ & coxa esq & braço esq \\
\hline 22 & 26 & M & $11^{\circ}$ & coxa esq & antebraço dir \\
\hline 23 & 22 & M & $12^{\circ}$ & coxa esq & $\begin{array}{l}\text { m. superior } \\
\text { esq }\end{array}$ \\
\hline
\end{tabular}

* PO - Tempo de pós-operatório, decorrido para a segunda biópsia

** AD - Área doadora

${ }^{* * *} \mathrm{AE}$ - Área enxertada 
Após a biópsia cada amostra AD e ENX foi dividida em 2 partes iguais, que foram estudadas por microscopia de luz e por imunofluorescência direta (imunomapeamento) (Figura 9).

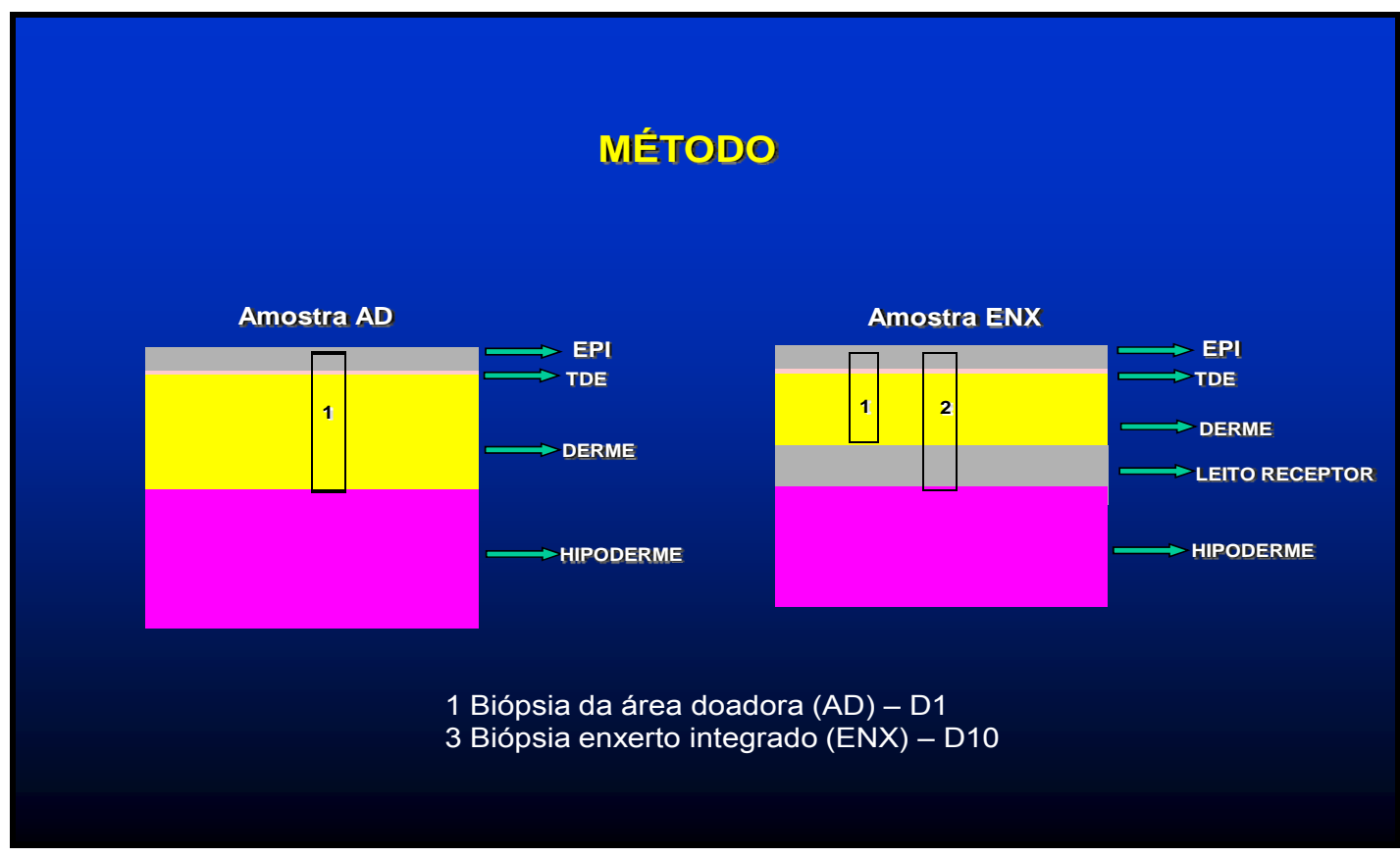

Figura 9. Quadro ilustrativo do método utilizado para a realização das biópsias no $1^{\circ}$ dia (D1) e após o $10^{\circ}$ dia (D10). Onde, (1) corresponde à biópsia da área doadora colhida em D1 e marcada com fio de náilon e (2) corresponde à biópsia da área enxertada 10 dias após a primeira biópsia, contendo o leito receptor

\subsection{Estudo Anatomopatológico por Microscopia de Luz}

No estudo anatomopatológico por microscopia de luz pesquisou-se, em cada biópsia, a relação entre a medida linear do relevo da transição dermoepidérmica - TDE -, a medida linear do relevo da superfície da epiderme - EPI - e a manutenção das papilas dérmicas. Na epiderme optouse por usar o relevo da superfície da camada granulosa, logo abaixo da camada córnea (Figura 10). 


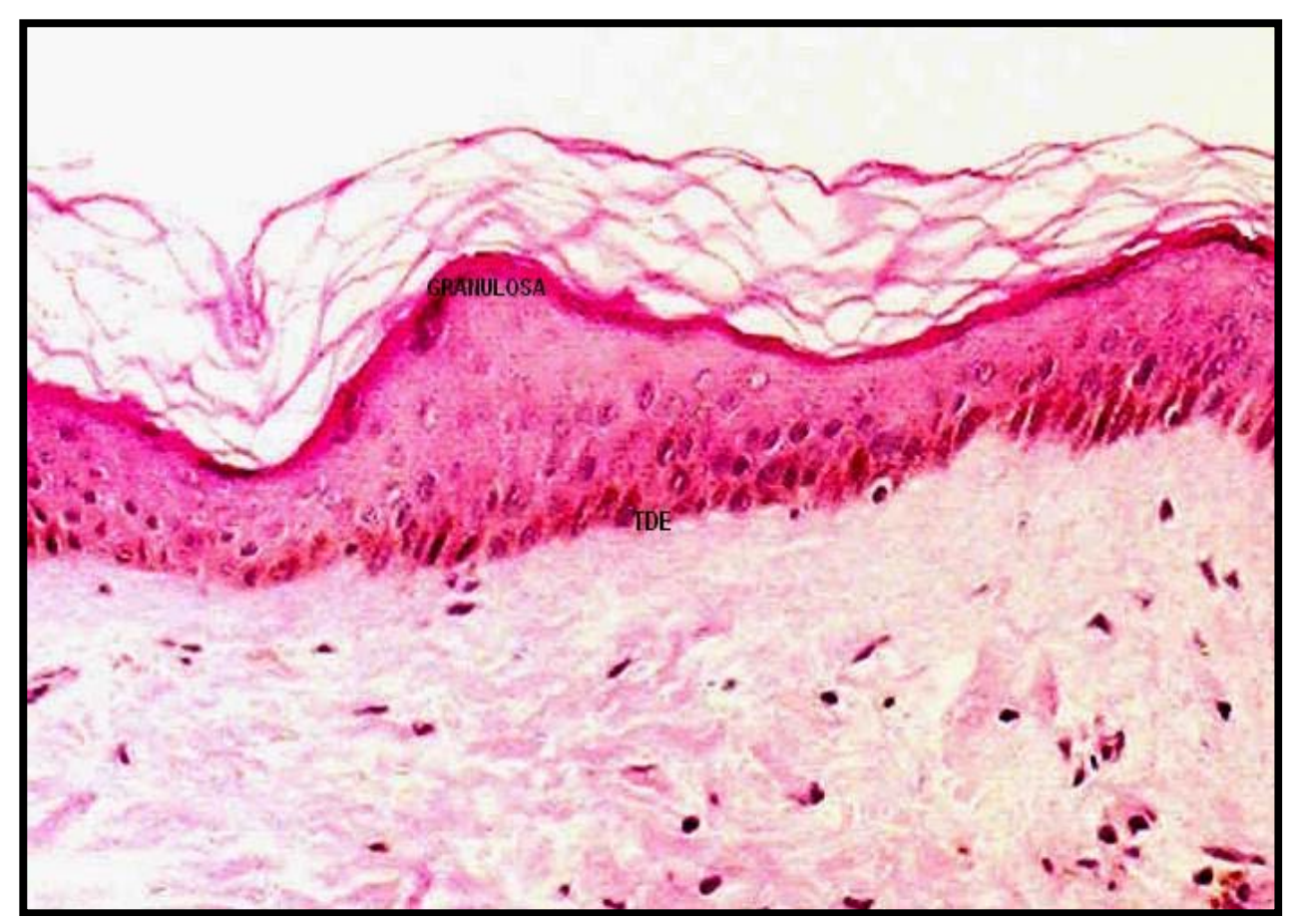

Figura 10. Fotografia da visualização da camada granulosa e da transição dermoepidérmica (TDE)

O estudo com microscópico de luz foi realizado pelo Laboratório de Dermatopatologia da Divisão de Dermatologia do HCFMUSP, após as amostras terem sido coradas pelo método da Hematoxilina Eosina (HE) e teve como finalidade:

- A comparação da morfologia das Amostras AD e ENX referidas como igual ou diferente, quando a diferença, se houver, seria caracterizada.

- Cálculo da relação entre o comprimento da epiderme (EPI) e o da transição dermoepidérmica (TDE), das amostras AD e ENX, pelo índice "TDE/EPI = N". Este índice foi usado como característica morfológica da transição. O cálculo foi feito por meio de fotografias digitais das amostras EPI e ENX após o devido preparo e a coloração por Hematoxilina Eosina. 
Foram preparadas 46 amostras param serem analisadas pela microscopia óptica, todas pela mesma técnica histológica, a HE, sendo 23 amostras das amostras AD e 23 das amostras ENX. Para cada amostra foram feitas, em média, 3 lâminas.

Essas amostras, depois de coradas e cortadas, geraram lâminas que foram fotografadas digitalmente, sempre com a mesma ampliação, para uso específico do programa de análise. Após o término do arquivo digital iniciouse a aferição das medidas lineares da TDE e da EPI, tanto das amostras AD como ENX.

As imagens digitalizadas foram transferidas para computador compatível com o padrão IBM e com o software ImageJ ${ }^{88}$.

Para este estudo foi utilizada máquina fotográfica digital Nikon® modelo Ds-Fil acoplada ao microscópio binocular Nikon® modelo Eclipse E 400 com aumento de $100 \mathrm{X}$.

O comprimento das medidas lineares, foi analisado nas fotografias digitais por meio do "software Image-J" e a unidade utilizada para esta aferição foi o "Pixel".

Este programa permitiu a realização das medidas lineares das amostras TDE e EPI, por meio da ferramenta do programa "seleção de linhas e linhas a mão livre", que quando acionadas possibilitavam a varredura das superfícies a serem mensuradas. Desta forma, as imagens varridas à mão livre (Figura 12) foram transferidas para o programa que, através de seus comandos, capturava os pixels das áreas varridas e as armazenava automaticamente em tabela Excel, calculando os resultados das medidas em pixels (Figura 11). 


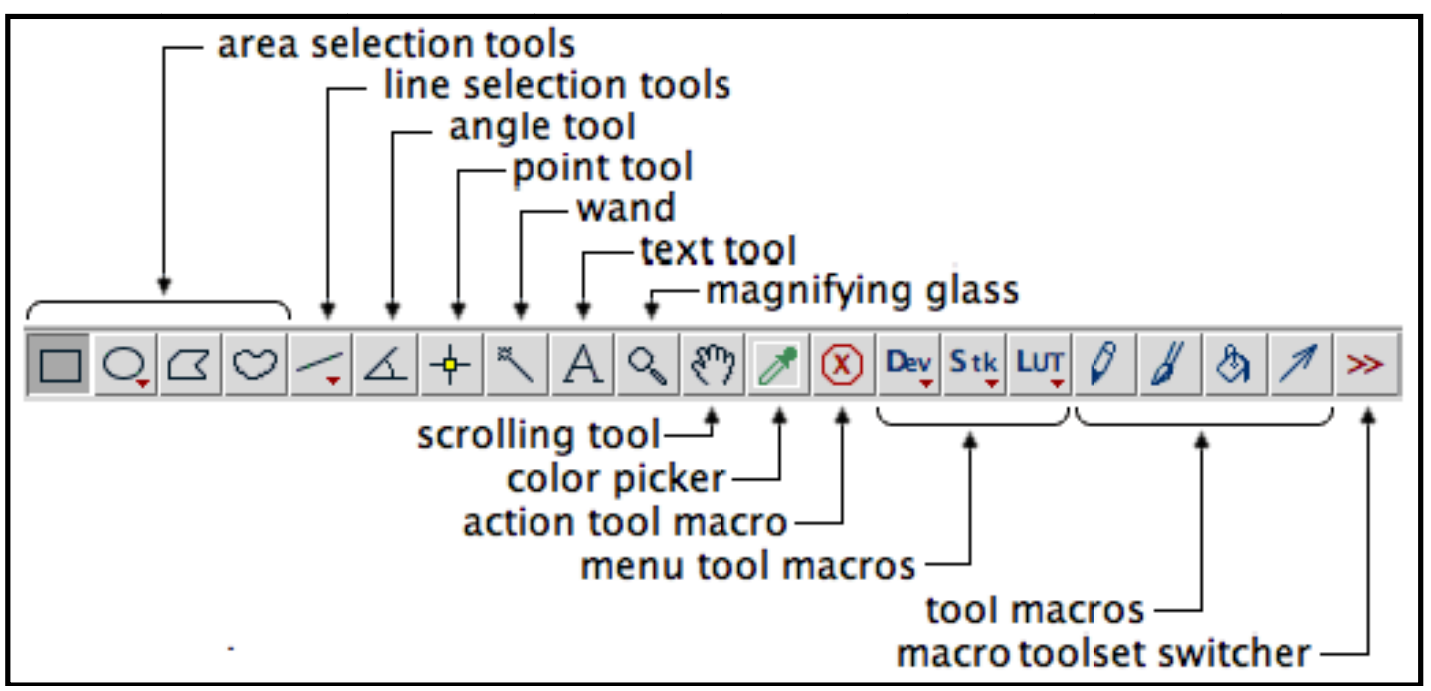

Figura 11. Barra de ferramentas do Image $\mathrm{J}$ com as diversas funções executadas pelo programa

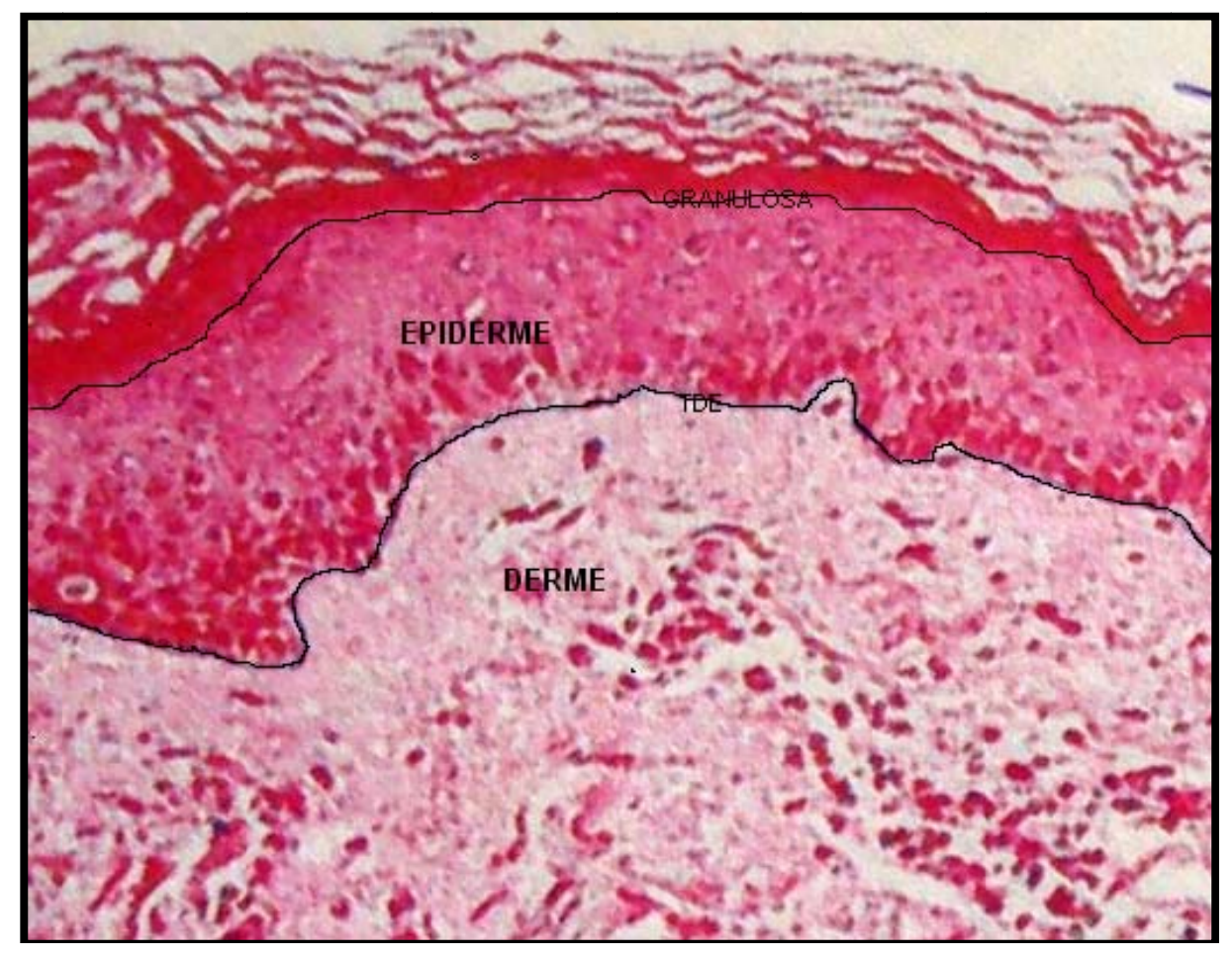

Figura 12. Fotografia da varredura feita pelo Image $\mathrm{J}$ em EPI e TDE de AD e ENX com aumento de 100X 


\subsection{Estudo por Imunofluorescência Direta}

$\mathrm{Na}$ imunofluorescência direta (imunomapeamento) pesquisou-se a possível alteração da membrana basal na TDE através dos antígenos penfigóide bolhoso, laminina, colágeno IV e colágeno VII.

O estudo por imunofluorescência direta para imunomapeamento foi realizado no Laboratório de Imunopatologia da Divisão de Dermatologia do Hospital das Clínicas da Faculdade de Medicina da Universidade de São Paulo (HCFMUSP).

A comparação morfológica por meio de imunomapeamento entre as amostras $A D$ e ENX teve como objetivo a visualização das camadas da membrana basal.

A técnica usada para o imunomapeamento foi:

As biópsias dos pacientes foram colhidas de áreas doadoras e áreas enxertadas. Até o processamento das biópsias estas foram mantidas em papel de alumínio contendo meio de inclusão para espécimes e sob uma temperatura de $20^{\circ} \mathrm{C}$ negativos (freezer).

As biópsias foram cortadas em criostato numa espessura de 4 micra e coladas sob as lâminas aluminizadas. Para cada amostra AD e ENX foram feitas quatro lâmias para análise de cada camada da ZMB. Assim foram analisadas 92 lâminas das amostras AD e 92 lâminas das amostras ENX, num total de 184 lâminas pesquisadas.

Foram utilizados os anticorpos monoclonais (produzidos em camundongo) anti-laminina humana (diluição de 1:20), anti-colágeno IV 
humano (diluição de 1:25) e anti- colágeno VII humano (diluição 1:25) marca Sigma Aldrich, adquiridos comercialmente.

Como fonte de anticorpo para o antígeno Penfigóide Bolhoso, utilizou-se o soro de um doente previamente diagnosticado (diluição de 1:20). As diluições foram realizadas em Tampão Tri Acetato de Cálcio (TBS pH 7,5). A função desses anticorpos é marcar as diferentes zonas da membrana basal (ZMB).

Desta forma teremos o antígeno do Penfigóide Bolhoso marcando a parte superior da Lâmina Lúcida (região dos hemidesmossomos) e a Laminina marcando a parte inferior; o colágeno IV marcando a Lâmina Densa e o colágeno VII a Sublâmina Densa (fibrilas de ancoragem). Os anticorpos após diluídos foram depositados cada um sob um corte e incubados por um período de 30 minutos em câmara úmida à temperatura ambiente. Findo este prazo as lâminas foram lavadas em TBS por dois períodos de 10 minutos.

A seguir, para se revelar a reação, foi utilizado anticorpo anti lgG conjugado com isotiocianato de fluoresceína. Para haver ligação aos anticorpos monoclonais foi utilizada uma lgG anti-camundongo (diluição 1:30) e para haver ligação aos antígeno do Penfigóide foi utilizada uma IgG anti-humana (diluição 1:30). As diluições foram realizadas em tampão TBS contendo 3 mg\% do corante Azul Evans (marca Inlab).

Após 30 minutos de incubação (em câmara úmida e temperatura ambiente) as lâminas foram novamente lavadas em TBS por dois períodos de 10 minutos. A seguir os cortes receberam glicerina tamponada (ph 9,0/0,5M) e 
lâmina de vidro. A leitura das lâminas foi feita em microscópio marca Carl Zeiss Axiolab HBO 50 com oculares de 10X e objetivas de 16X, acoplado à máquina digital AxioCam MRC 5.

Resumidamente, o imunomapeamento foi feito para cada amostra por meio de 4 cortes para marcar as 4 camadas da zona da membrana basal:

1. Região dos hemidesmossomos pelo antígeno Penfigóide Bolhoso;

2. Lâmina lúcida, parte inferior, pela Laminina;

3. Lâmina Densa pelo colágeno IV;

4. Sub-lâmina densa (fibrilas de ancoragem) pelo colágeno VII.

Na comparação entre as amostras $A D$ e as respectivas ENX foram consideradas a presença ou ausência das camadas e se elas eram contínuas ou descontínuas. A presença na Zona da Membrana Basal das 4 camadas contínuas caracterizou a estrutura normal e fisiológica da transição dermo-epidérmica. A ausência, no entanto, demonstrou alteração dessa estrutura. 


\section{RESULTADOS}




\subsection{Anatomopatológico}

Nos 23 pacientes as estruturas microscópicas tanto de AD como as de ENX permaneceram iguais, íntegras e com o mesmo padrão morfológico (Figuras 13 e 14).

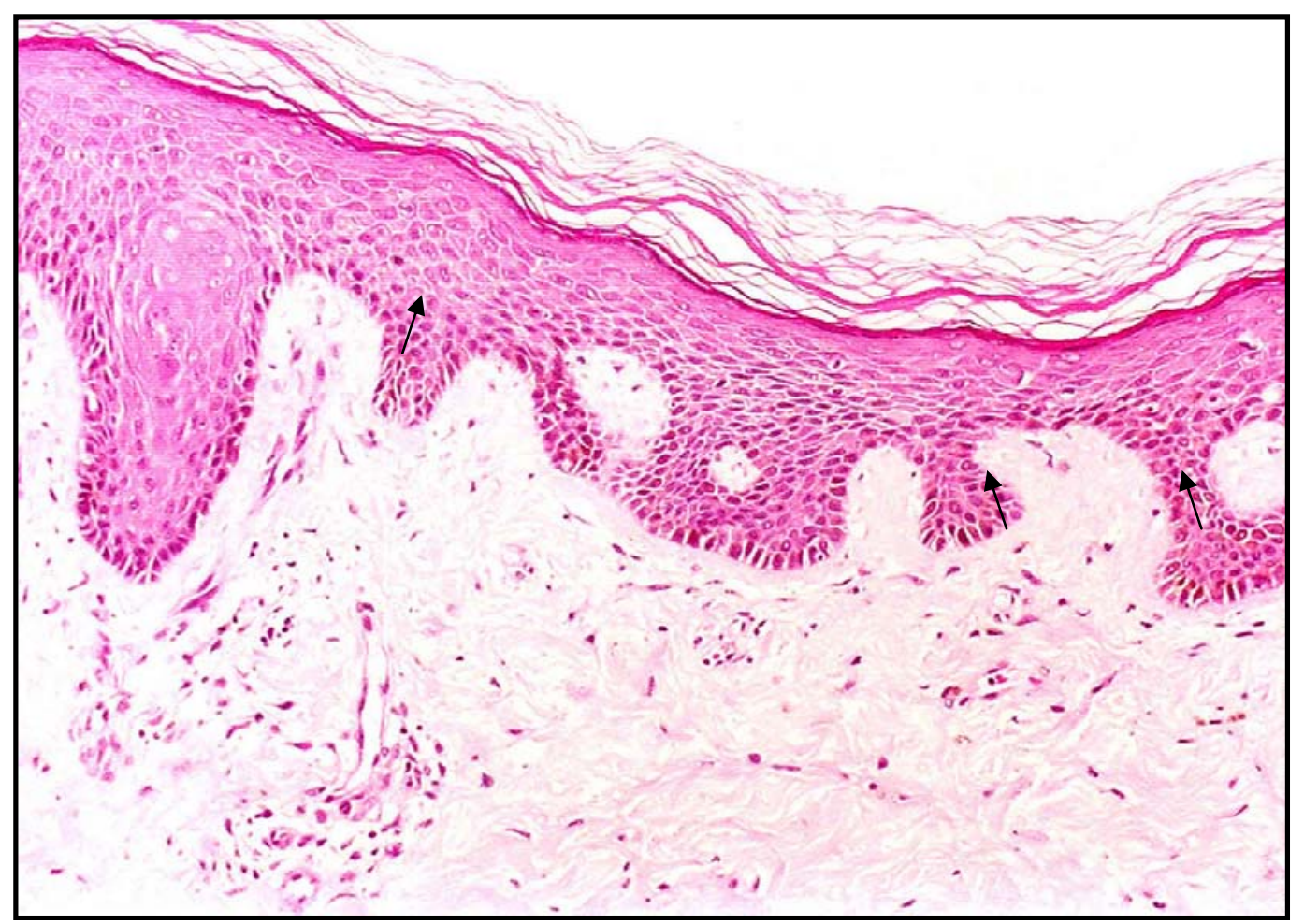

Figura 13. Fotografia da pele sã, amostra $A D$, onde todas as estruturas da epiderme e derme são visíveis inclusive as papilas dérmicas,indicadas pelas setas 


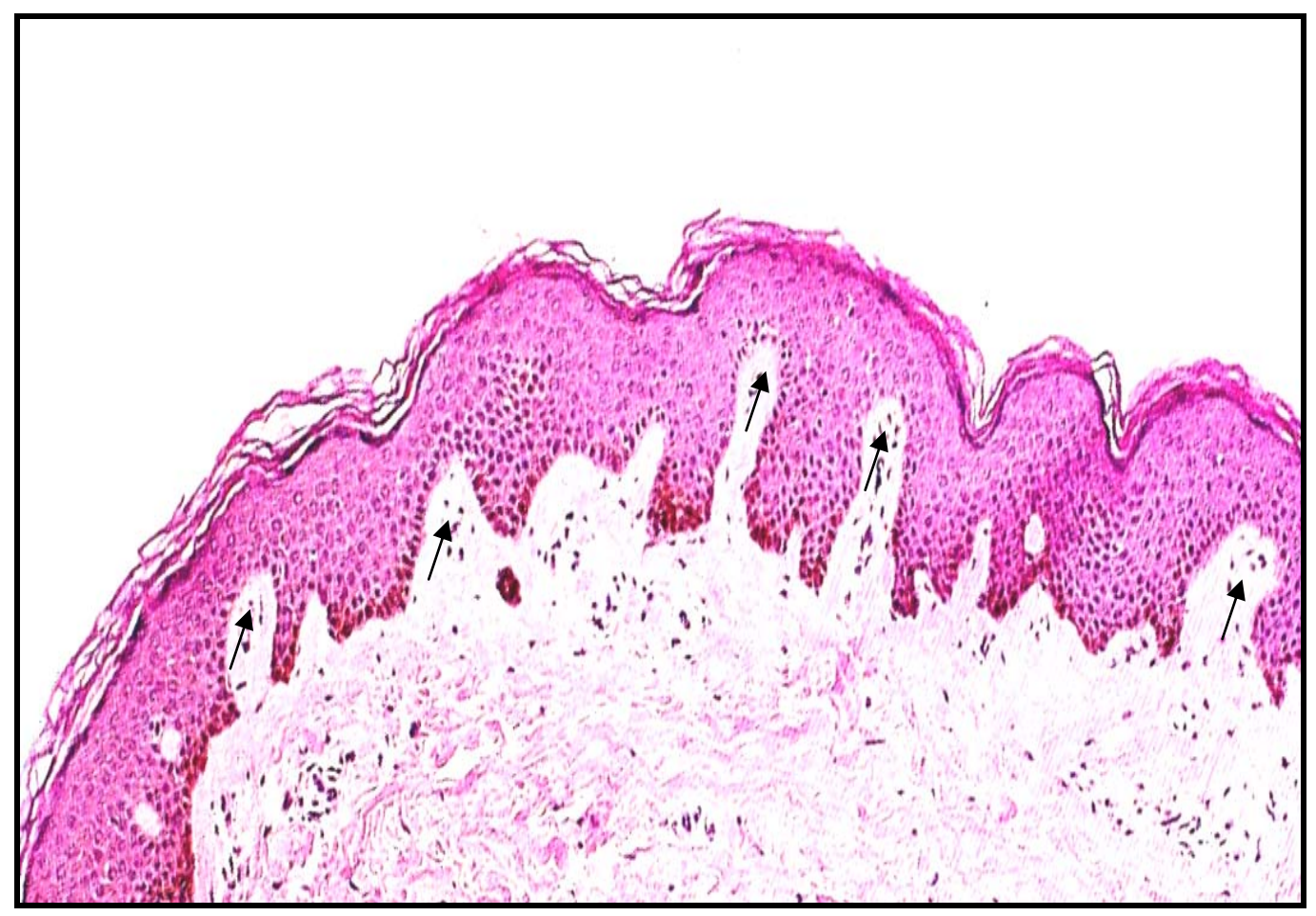

Figura 14. Fotografia da Área enxertada, amostra ENX, onde todas as estruturas da epiderme e derme são visíveis inclusive as papilas dérmicas, indicadas pelas setas

Quanto às medidas do comprimento linear houve aumento do índice $\mathrm{N}=$ TDE/EPI na amostra ENX, em comparação com a amostra AD (Tabelas 4, 5 e 6 e Figura 15). 
Tabela 4. Resultado das medidas lineares obtidas através da varredura do Image $\mathrm{J}$ e da relação TDE/EPI=N de AD

\begin{tabular}{|c|c|c|c|}
\hline \multirow{2}{*}{ Pacientes } & \multicolumn{3}{|c|}{ Área doadora - AD } \\
\hline & TDE & EPI & $\mathrm{TDE} / \mathrm{EPI}=\mathrm{N}$ \\
\hline 1 & 374,40 & 362,40 & 1,03 \\
\hline 2 & 469,22 & 454,33 & 1,03 \\
\hline 3 & 572,97 & 579,65 & 0,99 \\
\hline 4 & 523,87 & 488,21 & 1,07 \\
\hline 5 & 796,50 & 774,29 & 1,03 \\
\hline 6 & 342,37 & 327,90 & 1,04 \\
\hline 7 & 827,77 & 473,39 & 1,75 \\
\hline 8 & 455,38 & 363,44 & 1,25 \\
\hline 9 & 818,38 & 802,14 & 1,02 \\
\hline 10 & 734,87 & 732,34 & 1,00 \\
\hline 11 & 1808,10 & 1246,15 & 1,45 \\
\hline 12 & 515,04 & 489,88 & 1,05 \\
\hline 13 & 545,97 & 542,07 & 1,01 \\
\hline 14 & 449,35 & 410,08 & 1,10 \\
\hline 15 & 736,01 & 548,82 & 1,34 \\
\hline 16 & 463,66 & 359,53 & 1,29 \\
\hline 17 & 331,33 & 267,96 & 1,24 \\
\hline 18 & 450,12 & 366,76 & 1,23 \\
\hline 19 & 627,72 & 576,57 & 1,09 \\
\hline 20 & 619,04 & 441,69 & 1,40 \\
\hline 21 & 508,21 & 474,43 & 1,07 \\
\hline 22 & 621,85 & 559,00 & 1,11 \\
\hline 23 & 663,61 & 488,58 & 1,36 \\
\hline
\end{tabular}


Tabela 5. Resultado das medidas lineares obtidas através da varredura do Image $\mathrm{J}$ e da relação TDE/EPI=N de ENX

\begin{tabular}{|c|c|c|c|}
\hline \multirow{2}{*}{ Pacientes } & \multicolumn{3}{|c|}{ Área Enxertada - ENX } \\
\hline & EPI & TDE & TDE/EPI=N \\
\hline 1 & 387,76 & 513,40 & 1,32 \\
\hline 2 & 565,24 & 772,27 & 1,37 \\
\hline 3 & 741,88 & 924,10 & 1,25 \\
\hline 4 & 938,04 & 1293,55 & 1,38 \\
\hline 5 & 801,2 & 1267,80 & 1,58 \\
\hline 6 & 516,13 & 607,28 & 1,18 \\
\hline 7 & 771,15 & 1198,30 & 1,55 \\
\hline 8 & 444,93 & 733,05 & 1,65 \\
\hline 9 & 737,28 & 1105,85 & 1,50 \\
\hline 10 & 862,25 & 1123,28 & 1,30 \\
\hline 11 & 762,44 & 1821,52 & 2,39 \\
\hline 12 & 503,60 & 621,91 & 1,23 \\
\hline 13 & 375,80 & 408,66 & 1,09 \\
\hline 14 & 488,76 & 679,31 & 1,39 \\
\hline 15 & 518,15 & 780,47 & 1,51 \\
\hline 16 & 577,63 & 800,51 & 1,39 \\
\hline 17 & 410,72 & 537,03 & 1,31 \\
\hline 18 & 432,91 & 1153,68 & 2,66 \\
\hline 19 & 567,01 & 642,23 & 1,13 \\
\hline 20 & 524,77 & 587,07 & 1,12 \\
\hline 21 & 611,06 & 869,85 & 1,42 \\
\hline 22 & 402,95 & 514,55 & 1,28 \\
\hline 23 & 500,36 & 552,50 & 1,10 \\
\hline
\end{tabular}


Tabela 6 - Resultado da relação (TDE/EPI ENX) / (TDE/EPI AD) x 100. Este resultado mostra aumento do índice dos enxertos em relação a área doadora em média de $24 \%$

\begin{tabular}{|c|c|c|c|}
\hline Pacientes & EXERTO ENX & $\begin{array}{c}\text { ÁREA DOADORA } \\
\text { AD }\end{array}$ & $\begin{array}{c}\text { (TDE/EPI enx) } / \\
(\text { TDE/EPI ad) x } 100\end{array}$ \\
\hline & TDE/EPI=N & TDE/EPI=N & ENXIAD \\
\hline 1 & 1,32 & 1,03 & $128,16 \%$ \\
\hline 2 & 1,37 & 1,03 & $132,29 \%$ \\
\hline 3 & 1,25 & 0,99 & $126,01 \%$ \\
\hline 4 & 1,38 & 1,07 & $128,51 \%$ \\
\hline 5 & 1,58 & 1,03 & $153,82 \%$ \\
\hline 6 & 1,18 & 1,04 & $112,69 \%$ \\
\hline 7 & 1,55 & 1,75 & $88,87 \%$ \\
\hline 8 & 1,65 & 1,25 & $131,49 \%$ \\
\hline 9 & 1,50 & 1,02 & $147,01 \%$ \\
\hline 10 & 1,30 & 1,00 & $129,82 \%$ \\
\hline 11 & 2,39 & 1,45 & $164,65 \%$ \\
\hline 12 & 1,23 & 1,05 & $117,46 \%$ \\
\hline 13 & 1,09 & 1,01 & $107,97 \%$ \\
\hline 14 & 1,39 & 1,10 & $126,84 \%$ \\
\hline 15 & 1,51 & 1,34 & $112,32 \%$ \\
\hline 16 & 1,39 & 1,29 & $107,46 \%$ \\
\hline 17 & 1,31 & 1,24 & $105,74 \%$ \\
\hline 18 & 2,66 & 1,23 & $217,14 \%$ \\
\hline 19 & 1,13 & 1,09 & $104,04 \%$ \\
\hline 20 & 1,12 & 1,40 & $79,82 \%$ \\
\hline 21 & 1,42 & 1,07 & $132,89 \%$ \\
\hline 22 & 1,28 & 1,11 & $114,79 \%$ \\
\hline 23 & 1,10 & 1,36 & $81,30 \%$ \\
\hline
\end{tabular}



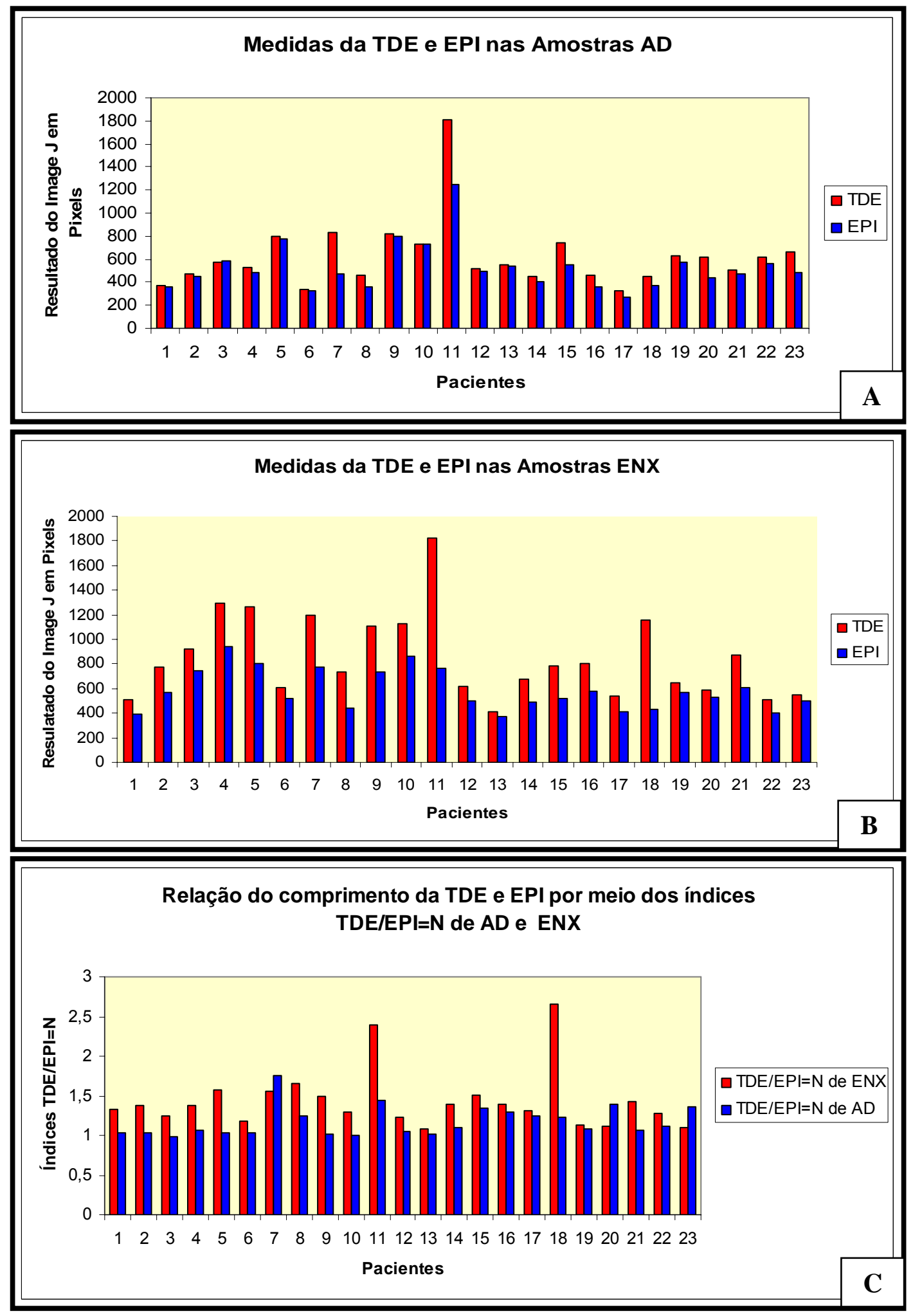

Figura 15. Gráficos das medidas lineares onde constam em $(A)$ as medidas de TDE e EPI em AD, em (B) as medidas da TDE e EPI em ENX e em (C) relação do comprimento da TDE e da EPI por meio do índice TDE/EPI=N de AD e ENX. 


\subsection{Análise Estatística}

A análise estatística dos índices das medidas lineares, das amostras de ENX com relação à $A D$, está representada nas tabelas 7 e 8 .

Tabela 7. Diferenças entre as medidas descritivas dos índices das medidas lineares de $A D$ e ENX e os percentuais resultantes

\begin{tabular}{|c|c|c|c|c|}
\hline \multirow[t]{2}{*}{ Amostra } & ENXERTO & $\begin{array}{c}\text { ÁREA } \\
\text { DOADORA }\end{array}$ & \multirow[t]{2}{*}{ Diferença } & \multirow{2}{*}{$\begin{array}{l}\text { Diferença } \\
\text { Percentua }\end{array}$} \\
\hline & TDE/EPI=N & TDE/EPI=N & & \\
\hline 1 & 1,32 & 1,03 & 0,29 & $28,2 \%$ \\
\hline 2 & 1,37 & 1,03 & 0,34 & $33,0 \%$ \\
\hline 3 & 1,25 & 0,99 & 0,26 & $26,3 \%$ \\
\hline 4 & 1,38 & 1,07 & 0,31 & $29,0 \%$ \\
\hline 5 & 1,58 & 1,03 & 0,55 & $53,4 \%$ \\
\hline 6 & 1,18 & 1,04 & 0,14 & $13,5 \%$ \\
\hline 7 & 1,55 & 1,75 & $-0,20$ & $-11,4 \%$ \\
\hline 8 & 1,65 & 1,25 & 0,40 & $32,0 \%$ \\
\hline 9 & 1,50 & 1,02 & 0,48 & $47,1 \%$ \\
\hline 10 & 1,30 & 1,00 & 0,30 & $30,0 \%$ \\
\hline 11 & 2,39 & 1,45 & 0,94 & $64,8 \%$ \\
\hline 12 & 1,23 & 1,05 & 0,18 & $17,1 \%$ \\
\hline 13 & 1,09 & 1,01 & 0,08 & $7,9 \%$ \\
\hline 14 & 1,39 & 1,10 & 0,29 & $26,4 \%$ \\
\hline 15 & 1,51 & 1,34 & 0,17 & $12,7 \%$ \\
\hline 16 & 1,39 & 1,29 & 0,10 & $7,8 \%$ \\
\hline 17 & 1,31 & 1,24 & 0,07 & $5,6 \%$ \\
\hline 18 & 2,66 & 1,23 & 1,43 & $116,3 \%$ \\
\hline 19 & 1,13 & 1,09 & 0,04 & $3,7 \%$ \\
\hline 20 & 1,12 & 1,40 & $-0,28$ & $-20,0 \%$ \\
\hline 21 & 1,42 & 1,07 & 0,35 & $32,7 \%$ \\
\hline 22 & 1,28 & 1,11 & 0,17 & $15,3 \%$ \\
\hline 23 & 1,10 & 1,36 & $-0,26$ & $-19,1 \%$ \\
\hline
\end{tabular}


Tabela 8. Resultado das análises estatísticas das medias descritivas de AD e ENX

\begin{tabular}{ccccc}
\hline Amostra & ENXERTO & ÁREA DOADORA & Diferença & Diferença \\
\hline & TDE/EPI=N & TDE/EPI=N & & percentual \\
\hline Média & 1,44 & 1,17 & 0,27 & $24,0 \%$ \\
Desvio padrão & 0,38 & 0,19 & 0,37 & $29,0 \%$ \\
Erro padrão da média & 0,08 & 0,04 & 0,08 & $6,0 \%$ \\
Mediana & 1,37 & 1,09 & 0,26 & $6,3 \%$ \\
Mínimo & 1,09 & 0,99 & $-0,28$ & $-20,0 \%$ \\
Máximo & 2,66 & 1,75 & 1,43 & $116,0 \%$ \\
\hline Diferença média & \multicolumn{5}{c}{0,27} \\
\hline Valor $p$ & $\mathbf{p = 0 0 2}$ \\
\hline
\end{tabular}

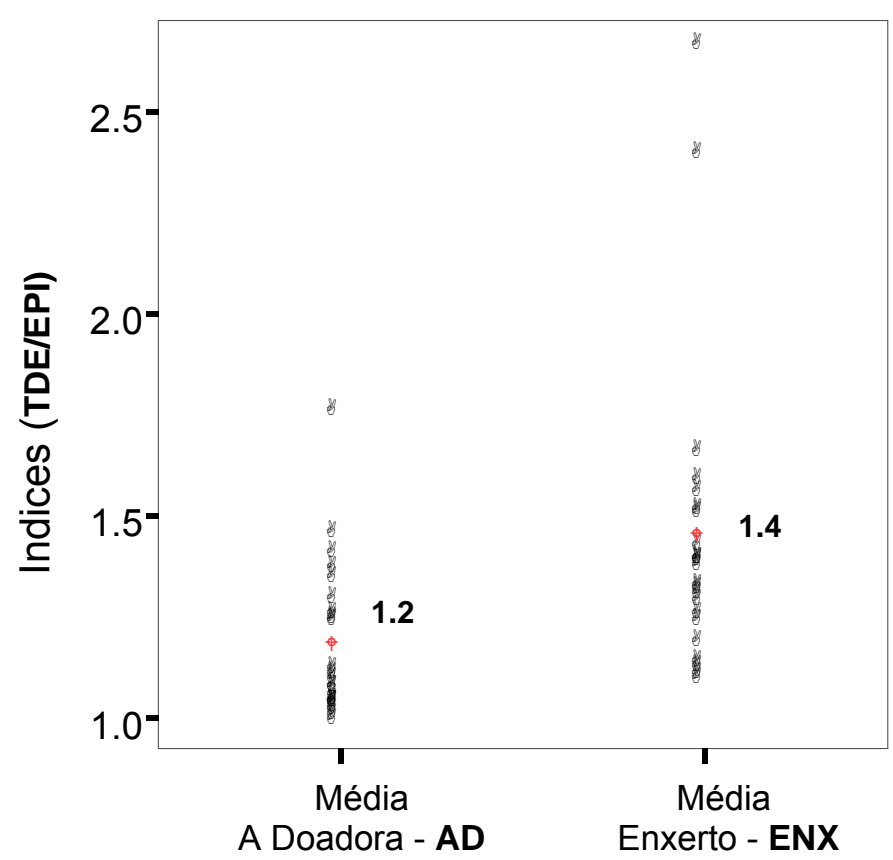

Dot/Lines show Means

Figura 16. Gráfico com valores individuais e médias em cada momento dos índices TDE/EPI=N de AD e ENX 
De acordo com as tabelas 7, 8 e figura 16 pode-se observar que ocorre um aumento linear médio de $24 \%$ das amostras ENX em relação às amostras AD, com um $p=0,002$ para o teste t de Student pareado.

Essa diferença é considerada estatisticamente significativa $(p<0,05)$.

Com o objetivo de avaliar o tamanho da amostra utilizada foi calculado o poder do teste, ou seja, a probabilidade de dizer que existe diferença de enxerto para área doadora, quando essa diferença realmente existe. Para um nível de significância de 5\%, o poder do teste foi de $92 \%$.

\subsection{Imunofluorescência direta}

Na imunofluorescência direta, a imunocomparação entre as amostras AD e as amostras ENX, por meio do imunomapeamento das quatro camadas que compõem a membrana basal, confirmou a existência de todas elas. A presença na membrana basal das 4 camadas contínuas caracterizou a estrutura normal e fisiológica da transição dermoepidérmica (Tabelas 9, 10 e Figuras 17 a 24). As figuras 17 e 18 são exemplos representativos da camada de hemidesmossomos, as de número 19 e 20 representam a lâmina lúcida, 21 e 22 representam a lâmina densa e 23 e 24 representam a sublâmina densa, das amostras AD e ENX respectivamente. 
Tabela 9. Resultado da imunofluorescência direta e imunomapeamento da Membrana Basal das amostras das áreas doadoras

\begin{tabular}{c} 
RESULTADO IMUNOFLUORESCÊNCIA DIRETA E IMUNOMAPEAMENTO \\
TRANSIÇÃO DERMOEPIDÉRMICA - TDE OU \\
ZONA DA MEMBRANA BASAL - ZMB \\
\hline
\end{tabular}

AMOSTRA AD

\begin{tabular}{|c|c|c|c|}
\hline \multicolumn{2}{|c|}{ CAMADAS } & \multicolumn{2}{|r|}{ ANTICORPOS/AC } \\
\hline \multicolumn{2}{|c|}{$\begin{array}{l}1 \text { - hemidesmossomos - HD } \\
2 \text { - lâmina lúcida - L } \\
3 \text { - lâmina densa - LD } \\
4 \text { - fibrilas de ancoragem - FA }\end{array}$} & \multicolumn{2}{|c|}{$\begin{array}{l}\text { AC contra antígeno do penfigóide bolhoso - AgPB } \\
\text { AC contra laminina - L } \\
\text { AC contra colágeno IV - C IV } \\
\text { AC contra colágeno VII - C VII }\end{array}$} \\
\hline CASO & $\mathrm{RHICHC}$ & Biópsias & RESULTADO \\
\hline 1 & $13492248 j$ & $H D-L-L D$ - FA & presença de fluorescência contínua \\
\hline 2 & $13493642 f$ & $H D-L-L D$ - FA & presença de fluorescência contínua \\
\hline 3 & $13493644 \mathrm{f}$ & $H D-L-L D-F A$ & presença de fluorescência contínua \\
\hline 4 & $4043248 \mathrm{k}$ & $H D-L-L D-F A$ & presença de fluorescência contínua \\
\hline 5 & $13588951 \mathrm{j}$ & $H D-L-L D-F A$ & presença de fluorescência contínua \\
\hline 6 & $13595701 \mathrm{i}$ & $H D-L-L D$ - FA & presença de fluorescência contínua \\
\hline 7 & $13597144 \mathrm{~h}$ & $H D-L-L D-F A$ & presença de fluorescência contínua \\
\hline 8 & 4015973 i & $H D-L-L D-F A$ & presença de fluorescência contínua \\
\hline 9 & 13630874 b & $H D-L-L D-F A$ & presença de fluorescência contínua \\
\hline 10 & 13633860 e & $H D-L-L D-F A$ & presença de fluorescência contínua \\
\hline 11 & $13641545 \mathrm{k}$ & $H D-L-L D$ - FA & presença de fluorescência contínua \\
\hline 12 & 13 823399j & $H D-L-L D$ - FA & presença de fluorescência contínua \\
\hline 13 & $13804913 a$ & $H D-L-L D-F A$ & presença de fluorescência contínua \\
\hline 14 & $13817950 d$ & $H D-L-L D$ - FA & presença de fluorescência contínua \\
\hline 15 & $13818624 \mathrm{e}$ & $H D-L-L D$ - FA & presença de fluorescência contínua \\
\hline 16 & $13818818 \mathrm{~g}$ & $H D-L-L D-F A$ & presença de fluorescência contínua \\
\hline 17 & 13 822677k & $H D-L-L D$ - FA & presença de fluorescência contínua \\
\hline 18 & $13823078 g$ & $H D-L-L D$ - FA & presença de fluorescência contínua \\
\hline 19 & $13824125 \mathrm{e}$ & $H D-L-L D-F A$ & presença de fluorescência contínua \\
\hline 20 & $13824946 j$ & $H D-L-L D$ - FA & presença de fluorescência contínua \\
\hline 21 & $13831352 k$ & $H D-L-L D$ - FA & presença de fluorescência contínua \\
\hline 22 & $13831726 \mathrm{k}$ & $H D-L-L D-F A$ & presença de fluorescência contínua \\
\hline 23 & $13832896 c$ & $H D-L-L D-F A$ & presença de fluorescência contínua \\
\hline
\end{tabular}


Tabela 10. Resultado da imunofluorescência direta e imunomapeamento da Membrana Basal das amostras dos enxertos

\begin{tabular}{c}
\hline RESULTADO IMUNOFLUORESCÊNCIA DIRETA E IMUNOMAPEAMENTO \\
TRANSIÇÃO DERMOEPIDÉRMICA - TDE OU \\
ZONA DA MEMBRANA BASAL - ZMB \\
\hline
\end{tabular}

\section{AMOSTRA ENX}

\begin{tabular}{|c|c|c|c|}
\hline \multicolumn{2}{|c|}{ CAMADAS } & \multicolumn{2}{|r|}{ ANTICORPOS/AC } \\
\hline \multicolumn{2}{|c|}{$\begin{array}{l}1 \text { - hemidesmossomos - HD } \\
2 \text { - lâmina lúcida - L } \\
3 \text { - lâmina densa - LD } \\
4 \text { - fibrilas de ancoragem - FA }\end{array}$} & \multicolumn{2}{|c|}{$\begin{array}{l}\text { AC contra antígeno do penfigóide bolhoso - AgPB } \\
\text { AC contra laminina - L } \\
\text { AC contra colágeno IV - C IV } \\
\text { AC contra colágeno VII - C VII }\end{array}$} \\
\hline CASO & $\mathrm{RHICHC}$ & Biópsias & RESULTADO \\
\hline 1 & $13492248 j$ & $H D-L-L D-F A$ & presença de fluorescência contínua \\
\hline 2 & $13493642 \mathrm{f}$ & $H D-L-L D-F A$ & presença de fluorescência contínua \\
\hline 3 & $13493644 \mathrm{f}$ & $H D-L-L D-F A$ & presença de fluorescência contínua \\
\hline 4 & $4043248 \mathrm{k}$ & $H D-L-L D-F A$ & presença de fluorescência contínua \\
\hline 5 & $13588951 j$ & $H D-L-L D-F A$ & presença de fluorescência contínua \\
\hline 6 & $13595701 \mathrm{i}$ & $H D-L-L D-F A$ & presença de fluorescência contínua \\
\hline 7 & $13597144 \mathrm{~h}$ & $H D-L-L D-F A$ & presença de fluorescência contínua \\
\hline 8 & $4015973 i$ & $H D-L-L D-F A$ & presença de fluorescência contínua \\
\hline 9 & $13630874 \mathrm{~b}$ & $H D-L-L D-F A$ & presença de fluorescência contínua \\
\hline 10 & 13633860 e & $H D-L-L D-F A$ & presença de fluorescência contínua \\
\hline 11 & $13641545 \mathrm{k}$ & $H D-L-L D-F A$ & presença de fluorescência contínua \\
\hline 12 & 13 823399j & $H D-L-L D-F A$ & presença de fluorescência contínua \\
\hline 13 & $13804913 a$ & $H D-L-L D-F A$ & presença de fluorescência contínua \\
\hline 14 & $13817950 d$ & $H D-L-L D-F A$ & presença de fluorescência contínua \\
\hline 15 & $13818624 \mathrm{e}$ & $H D-L-L D-F A$ & presença de fluorescência contínua \\
\hline 16 & $13818818 \mathrm{~g}$ & $H D-L-L D-F A$ & presença de fluorescência contínua \\
\hline 17 & $13822677 \mathrm{k}$ & $H D-L-L D-F A$ & presença de fluorescência contínua \\
\hline 18 & $13823078 \mathrm{~g}$ & $H D-L-L D-F A$ & presença de fluorescência contínua \\
\hline 19 & $13824125 \mathrm{e}$ & $H D-L-L D-F A$ & presença de fluorescência contínua \\
\hline 20 & $13824946 j$ & $H D-L-L D-F A$ & presença de fluorescência contínua \\
\hline 21 & $13831352 k$ & $H D-L-L D-F A$ & presença de fluorescência contínua \\
\hline 22 & 13 831726k & $H D-L-L D-F A$ & presença de fluorescência contínua \\
\hline 23 & $13832896 c$ & $H D-L-L D-F A$ & presença de fluorescência contínua \\
\hline
\end{tabular}




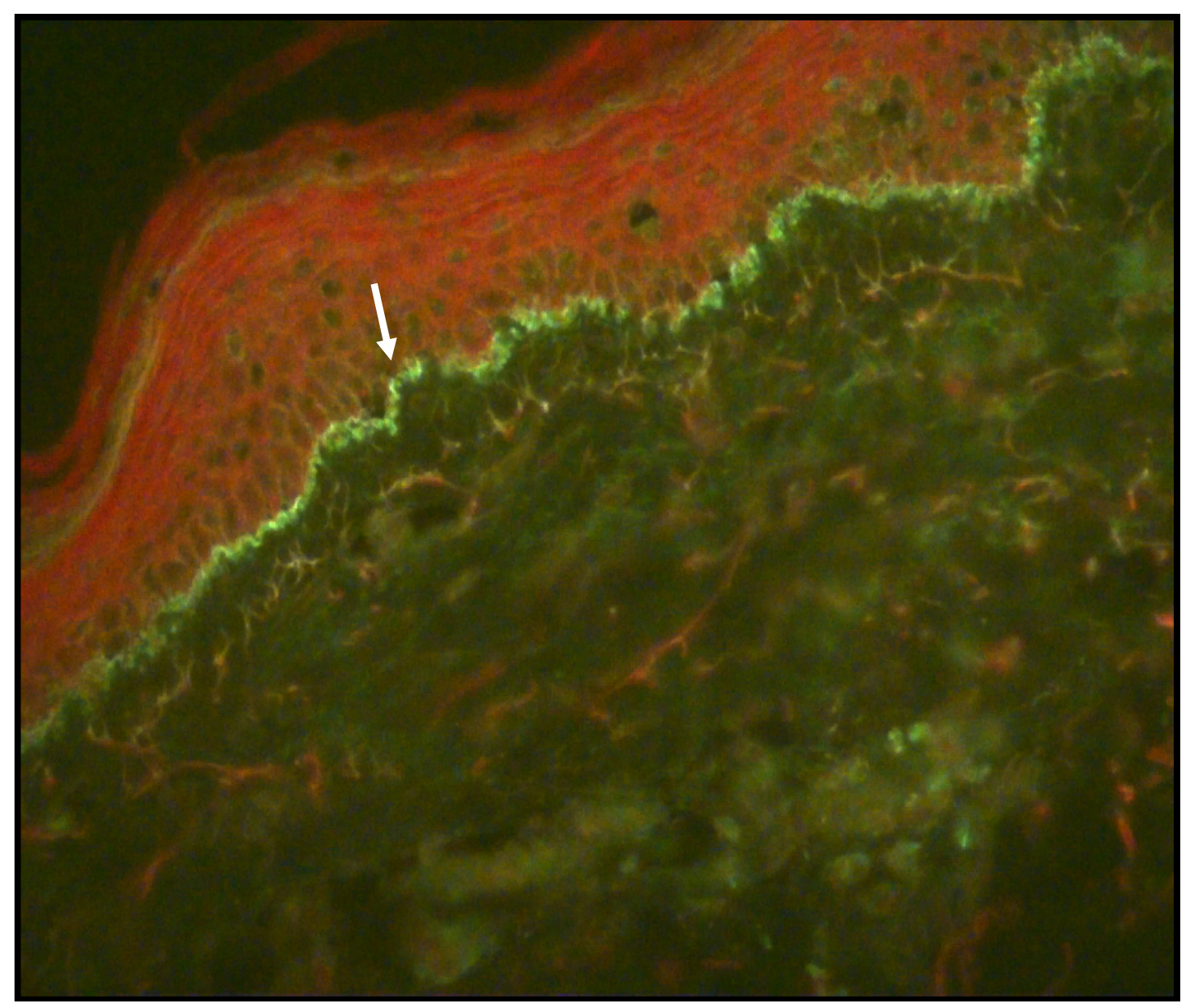

Figura 17. Fotografia da $A M B$ da $A D$ com aumento de 160X. A seta indica linha contínua fluorescente verde representa a camada de hemidesmossomos 


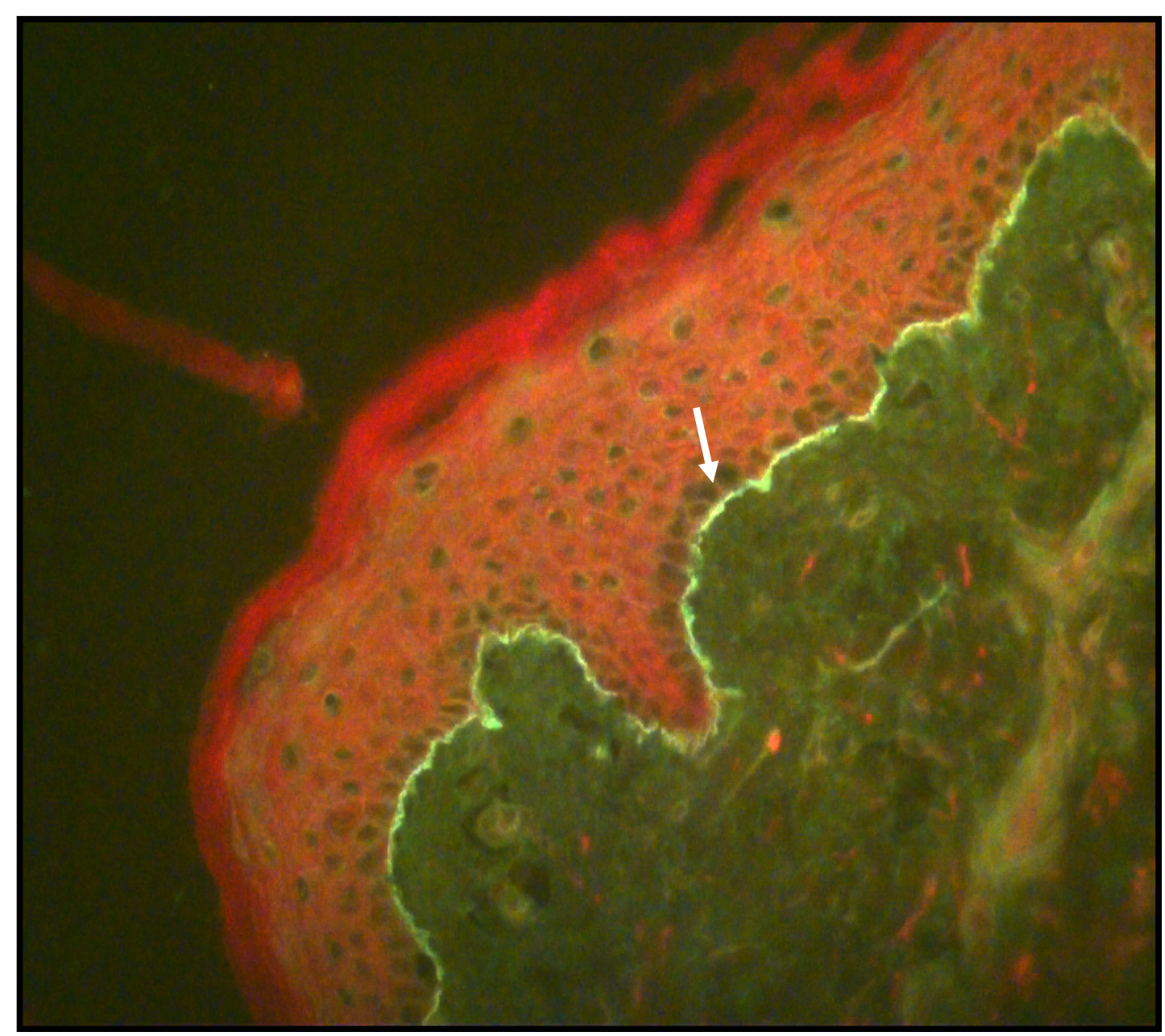

Figura 18. Fotografia da AMB de ENX com aumento de 160X. A seta indica linha contínua fluorescente verde representa a camada de Hemidesmossomos 


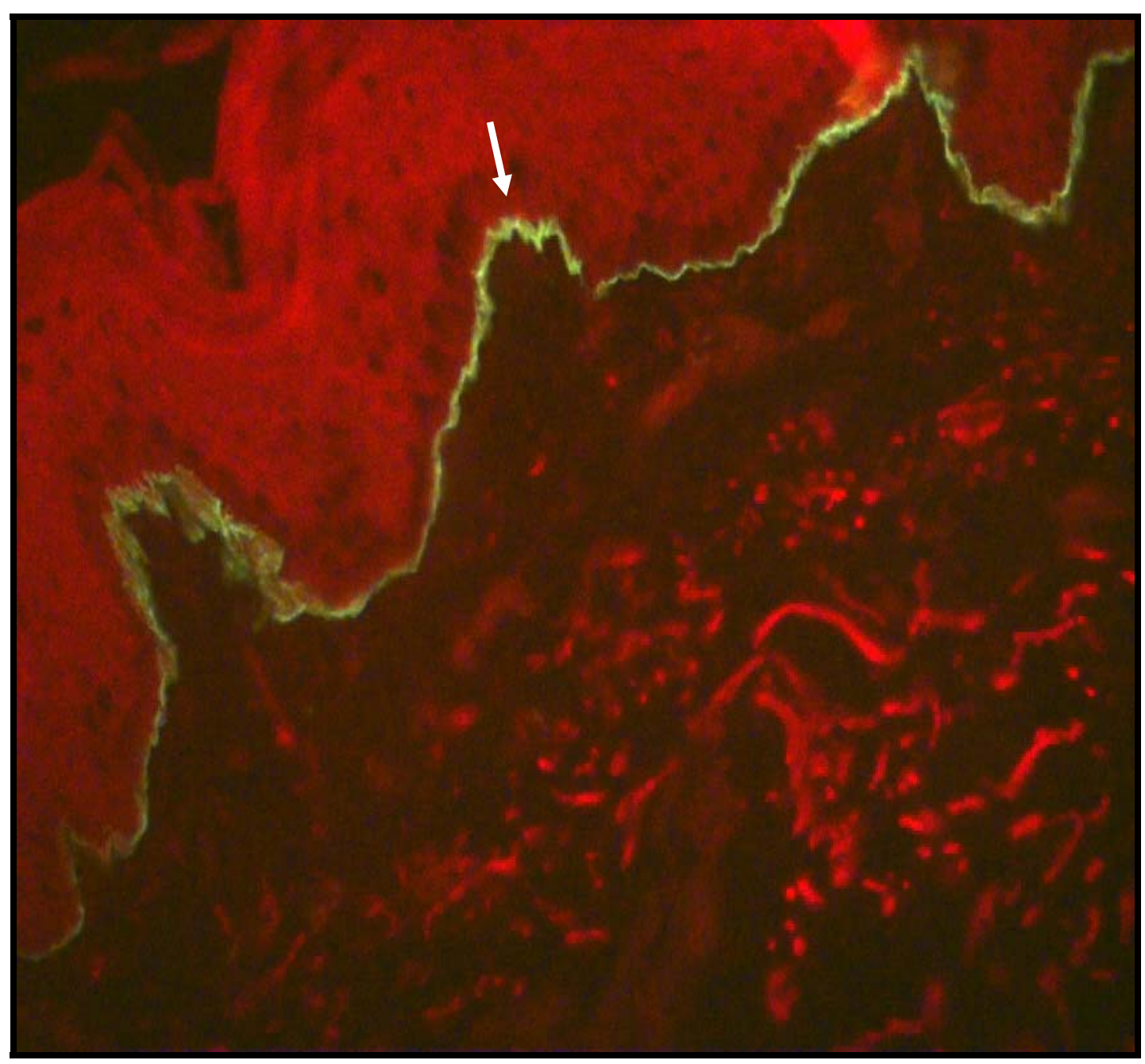

Figura 19. Fotografia da $A M B$ de $A D$ com aumento de 160X. A seta indica linha contínua fluorescente verde representa a lâmina lúcida 


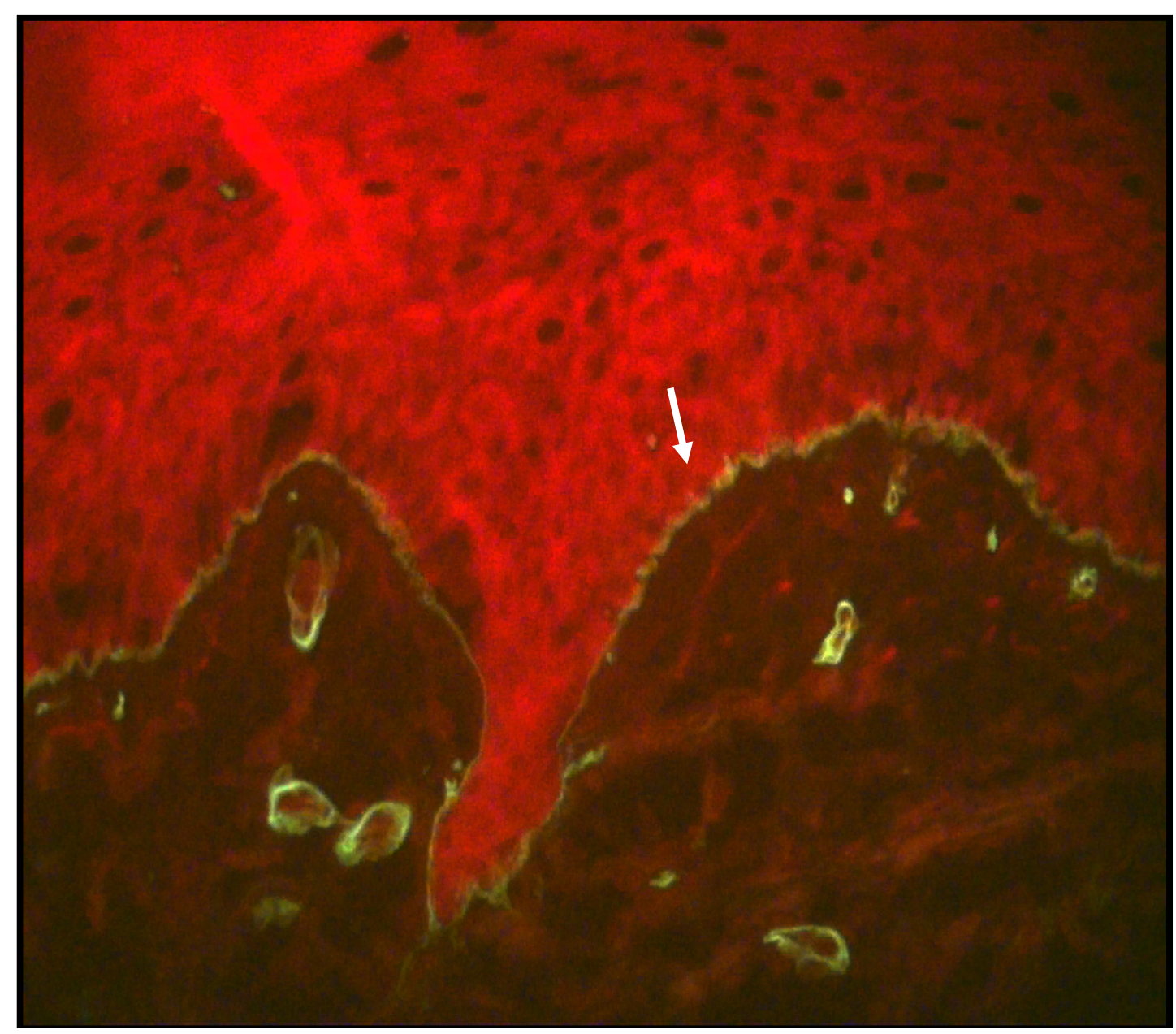

Figura 20. Fotografia da ZMB de ENX com aumento de 160X. A seta indica linha contínua fluorescente verde representa a lâmina lúcida 


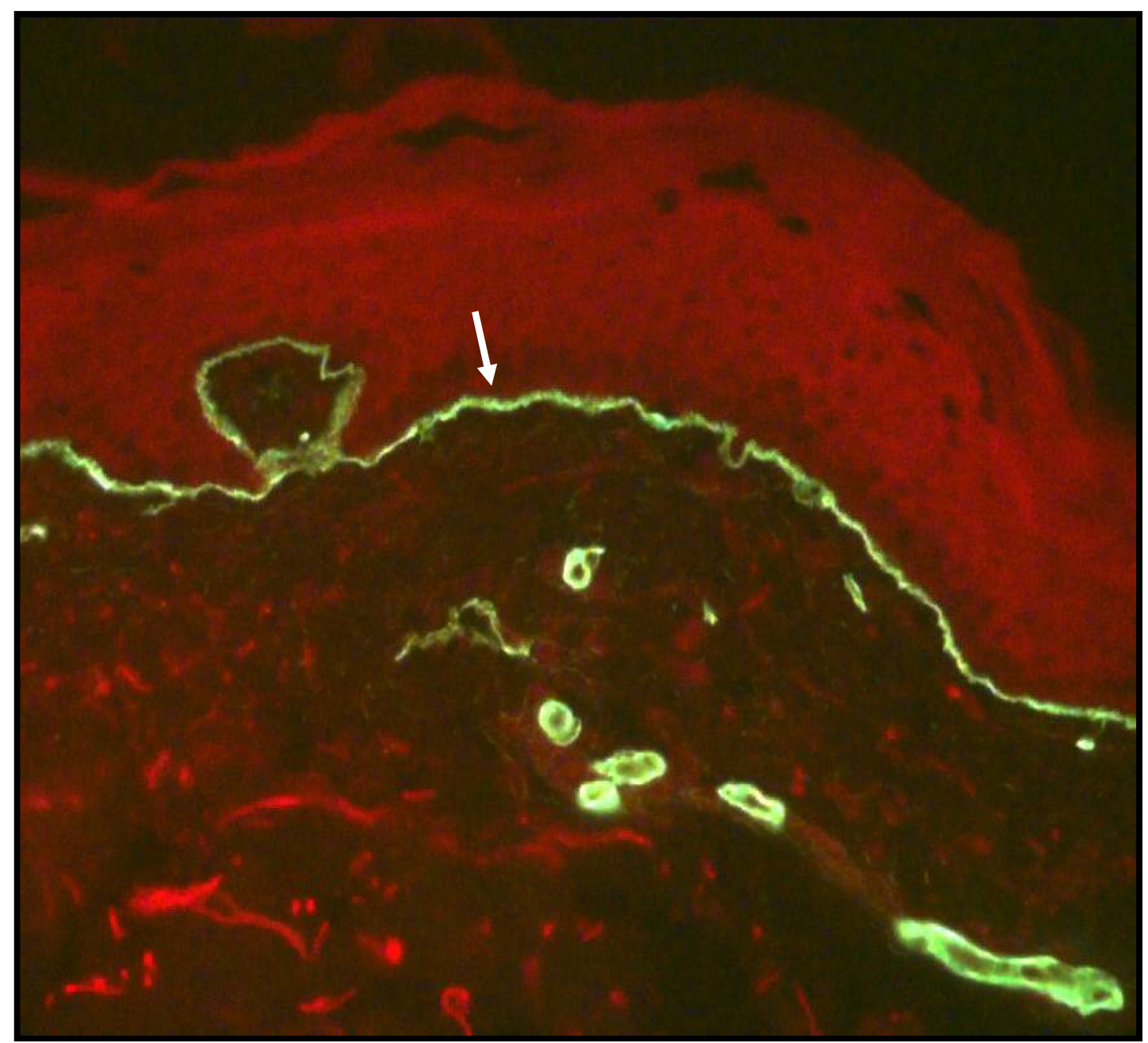

Figura 21. Fotografia da ZMB de AD com aumento de 160X. A seta indica linha contínua fluorescente verde representa a lâmina densa 


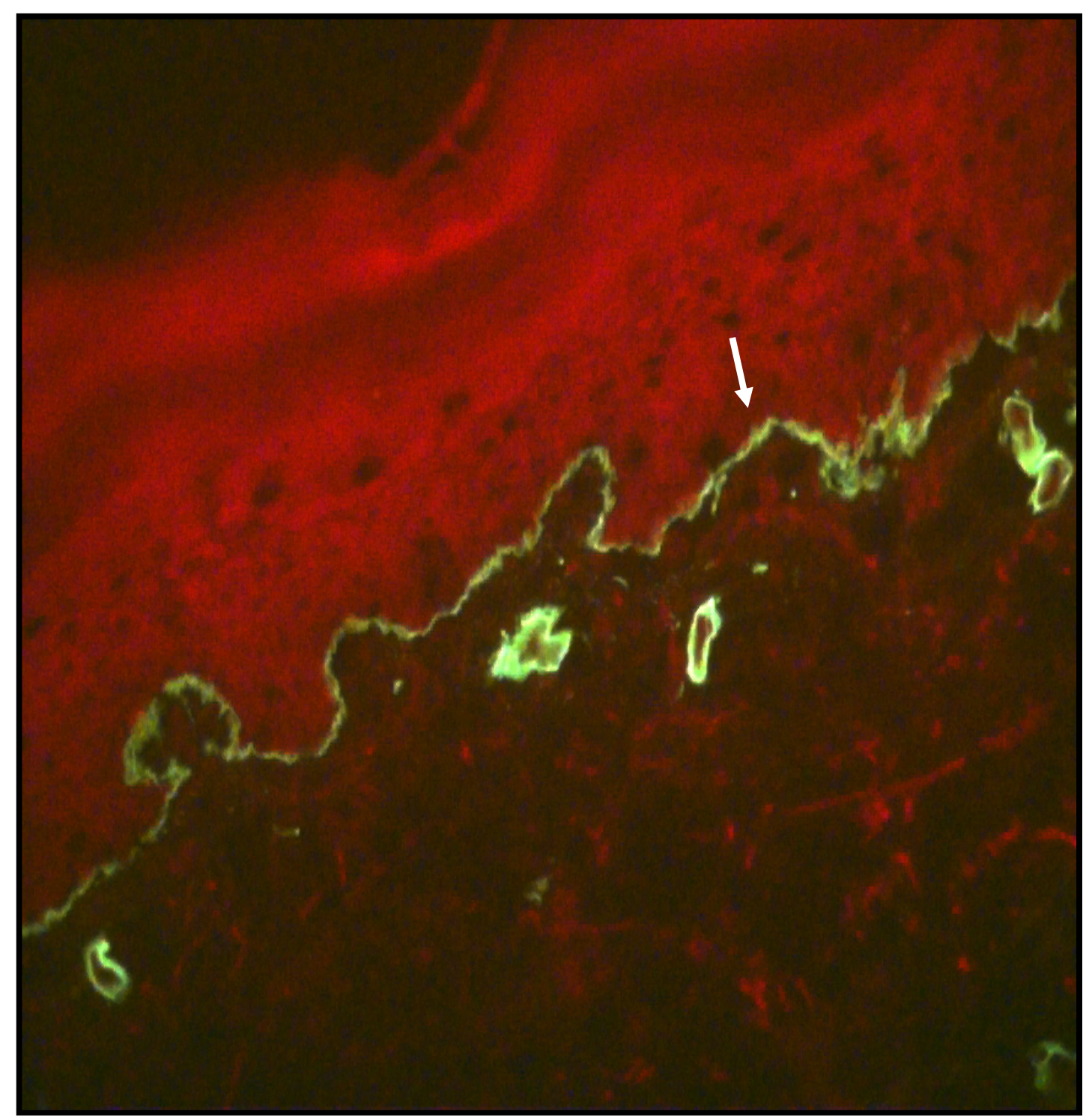

Figura 22. Fotografia da ZMB de ENX com aumento de 160X. A seta indica linha contínua fluorescente verde representa a lâmina densa. 


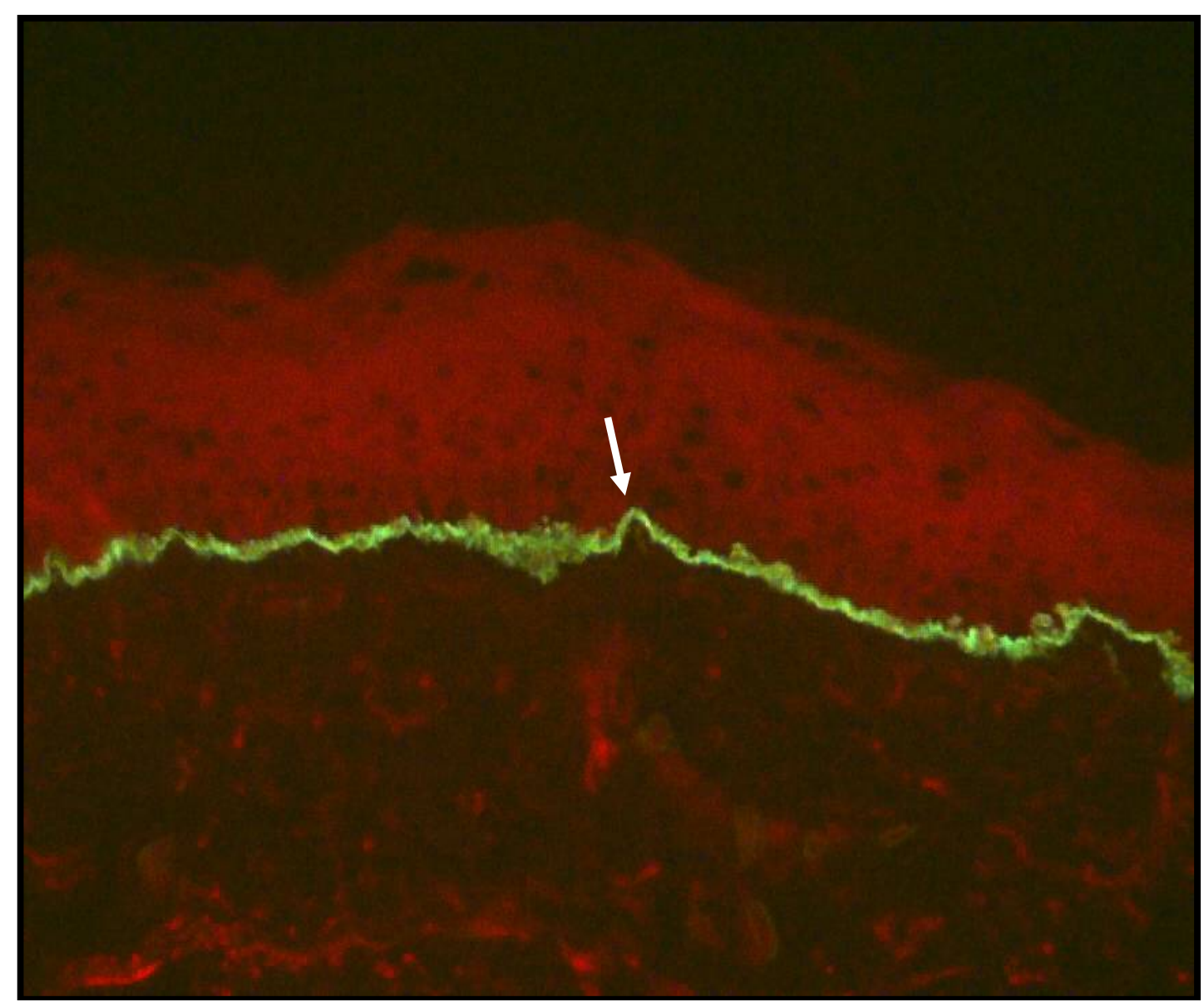

Figura 23. Fotografia da ZMB de AD com aumento de 160X. A seta indica linha contínua fluorescente verde representa de sub-lâmina densa 


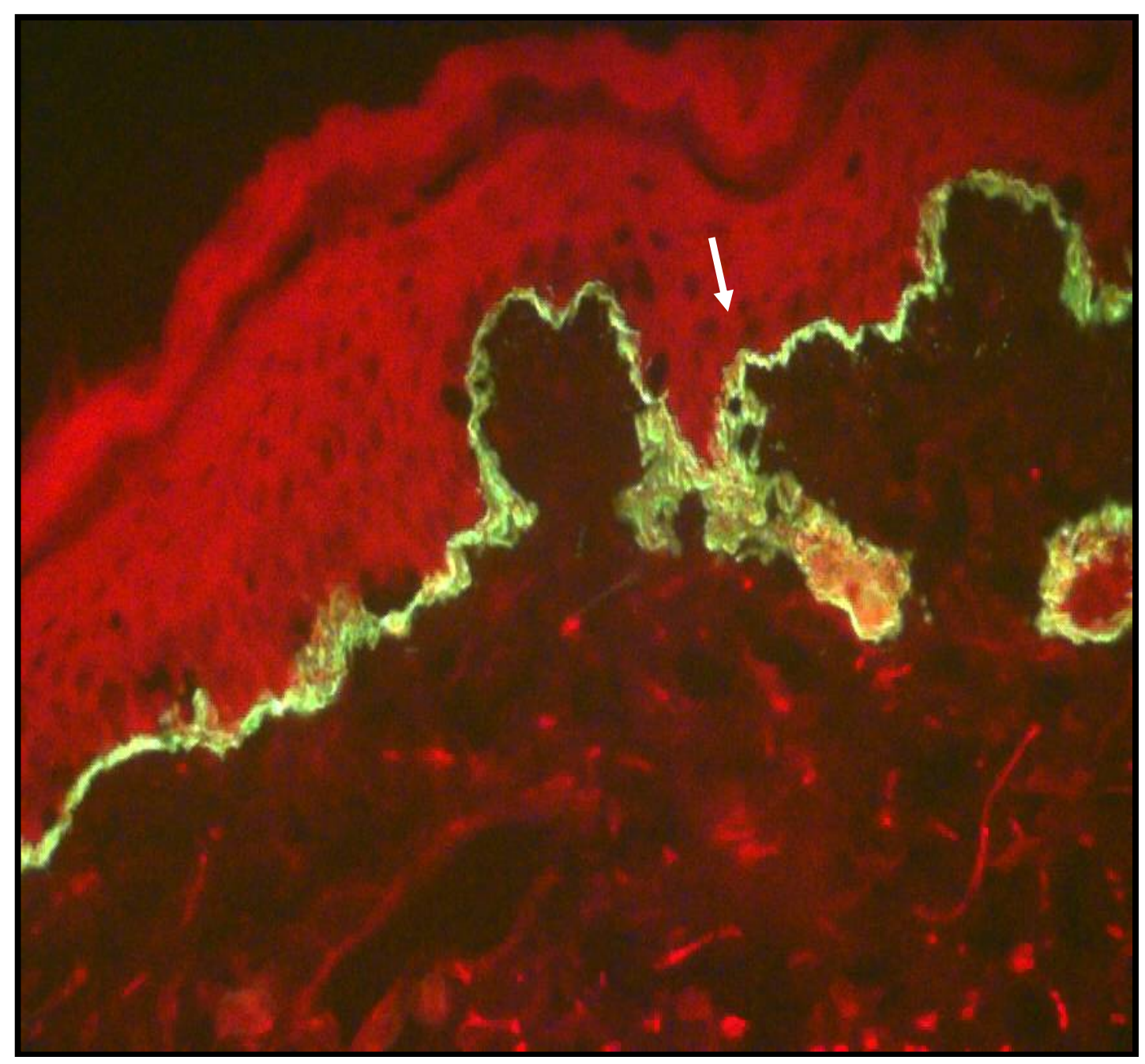

Figura 24. Fotografia da ZMB de ENX com aumento de 160X. A seta indica linha contínua fluorescente verde representa a sub-lâmina densa 
6 DISCUSSÃO 
Uma importante estrutura participa da junção da derme à epiderme na transição demoepidérmica, a membrana basal (MB) (vide item 3.2.2). Na pele humana, a membrana basal, ou zona da membrana basal (ZMB), é uma delgada lâmina de matriz extracelular (MEC) que está situada entre a barreira externa da pele, a epiderme, e a barreira interna a derme. A membrana basal na pele humana é constituída de uma lâmina basal e uma lâmina reticular adjacente ao tecido conjuntivo onde, nesta última, estão presentes as fibrilas de ancoragem, importantes estruturas de ligação da MB com a derme. A maior função da ZMB é realizar uma aderente junção entre a epiderme e a derme ${ }^{68}$

A ZMB, composta principalmente por colágeno tipo IV, laminina (glicoproteína) e proteoglicanas, permite a formação de barreiras e canais entre camadas celulares interativas. Não é uma estrutura estática, e sim dinâmica, remodelada constantemente, por processos de rupturas e sínteses de glicoproteínas ${ }^{92}$.

Estes processos são de suma importância na inflamação e no reparo, pois a membrana necessita ser fragmentada para que haja a entrada e saída de células, que participam ativamente do processo inflamatório. Essa fragmentação precisa ser reparada de forma rápida, organizada e precisa, e esse processo não acontece na presença de células tumorais ${ }^{92}$. 
A membrana basal e seus auto-antígenos envolvidos em reações auto-imunes, são a causa de doenças auto-imunes na pele. Exemplos dessas doenças são a epidermólise bolhosa e a epidermólise bolhosa distrófica, que estão relacionadas a mutações do gene do colágeno VII e em defeitos na produção de laminina-5, BP180, e integrina, que se manifestam clinicamente pela presença de bolhas devido à fragilidade na estrutura das camadas de hemidesmossomos, lâmina lúcida e lâmina densa (Figura 3, item 3.2.2).

Essa, no entanto, não é a gênese da formação das vesículas subepidérmicas que ocorrem em tegumentos neoformados e áreas de enxertia de pele, mas de forma semelhante, o surgimento de vesículas nestas áreas também poderia ser atribuído a alterações na zona da membrana basal.

A literatura descreve casos de enxertia de epiderme cultivada para tratar queimaduras, mas a má aderência dos enxertos, leva a formação de vesículas que se rompem, ulceram e tornam o resultado da enxertia insatisfatório. Esta má aderência tem sido atribuída às falhas na reconstrução dermoepidérmica ${ }^{1}$.

No processo de cura de queimaduras de primeiro grau, há regeneração da pele. As queimaduras de espessura parcial e as áreas doadoras restauradas dão origem à pele restaurada, à custa de epitelização a partir dos anexos da pele e neoformação do tecido conjuntivo. Também ocorre epitelização na cicatrização por segunda intenção de úlceras e nas enxertias de pele em malha ${ }^{16}$. 
Em todas as circunstâncias citadas, onde houve a cura das lesões por restauração, cicatrização, uso de enxertos em malha ou enxertos com queratinócitos cultivados, ocorreu a neoformação do tegumento, com reconstrução da transição dermoepidérmica e consequente neoformação da zona da membrana basal, que poderia gerar falhas na aderência e resultar no surgimento de vesículas ${ }^{16}$.

Gomez, Ferreira e Mariani, revisaram a literatura em 2005 e publicaram o trabalho "The problem of subepidermal blisters in neoformed integuments" e discutem a questão do surgimento de vesículas em enxertos de pele ${ }^{16}$.

Neste trabalho a literatura, entre 1980 e 2001, constam apenas 8 referências que estudam 31 doentes com 34 casos de vesículas em áreas de tegumentos neoformados e de enxertia de pele que estão distribuídos como se vê na Tabela 2 (item 3.5) 8,9,10,11,12,13,15.

Em análise apurada destas referências, pode-se perceber que essas vesículas eram citadas simplesmente por surgir em áreas onde a aderência da derme à epiderme era pobre devido à neoformação dos tegumentos sem dar muita importância à anatomia clínico-patológica na formação desses tecidos. Assim, estes autores citam vesículas que se desenvolveram em área doadora de paciente psoriático ${ }^{8}$, ou em áreas doadoras de enxertos de pele ${ }^{9}$. Baran em $1984{ }^{10}$ relata vesículas em áreas doadoras e em enxertos de pele realizados por meio da técnica de Davis (enxertos em selos) onde existe cicatrização por segunda intenção. Pedragosa e col. ${ }^{11}$, descrevem o caso de uma criança de 11 meses de idade que apresentou vesículas em queimadura que curou normalmente após 30 dias, sem mencionar ato cirúrgico. 
Epstein e col. ${ }^{12}$ realizam o estudo de um paciente grave com $71 \%$ de superfície corpórea queimada que depois de repetidas escarectomias e enxertias de pele apresentou, após a cura, vesículas em área de enxertia de pele. No entanto, este trabalho não apresenta nenhuma evidência histológica das vesículas nas áreas enxertadas. Woodley e col. ${ }^{13}$, citam os enxertos epidérmicos (queratinócitos cultivados) para tratar feridas de queimaduras que apresentam reconstrução anormal das fibrilas de ancoragem na membrana basal.

Chetty e col. ${ }^{14}$ foram os autores que melhor explicaram o surgimento de vesículas tanto em áreas doadoras, áreas restauradas e em cicatrizes de enxertos de pele "em malha", onde a análise das biópsias evidenciou defeitos na zona da membrana basal. Bergman e col. ${ }^{15}$ fizeram referência ao surgimento de vesículas tardias onde o assoalho das mesmas era formado por tecido fibrótico sem dar evidências reais de que realmente foram originadas nos enxertos.

Neste mesmo trabalho (Tabela 2), a literatura acusa 19 casos $(55,1 \%)$ de vesículas em enxertos o que está em desacordo com o estudo de Mariani e col. ${ }^{16}$, onde em cem doentes queimados curados não foi verificado nenhum caso de vesícula em enxerto. Este fato confirma nossa experiência clínica assim como a de Jo-David Fine - co-autor do trabalho de Epstein ${ }^{12}$ que refere não ter encontrado vesículas em 600 casos de enxertia de pele.

O método utilizado pelos autores dos trabalhos citados, para chegar às suas conclusões, foi o da realização de biópsias em áreas de enxertia de pele. Percebe-se, pela leitura dos trabalhos e pelo resultado de alguns 
exames histopatológicos, que a maioria dessas biópsias foi colhida entre as lâminas dos enxertos onde havia tecido cicatricial.

Gomez e col. ${ }^{16}$ citam em seu trabalho que o termo enxerto de pele, como usado na literatura, é ambíguo e não pode ser aceito como enxertia de pele e sim como áreas de enxertias de pele. Também menciona que biópsias de áreas enxertadas que contém cicatrizes e tecido restaurado, não são biópsias de enxertos de pele. Discute, ainda, que na área receptora só pode existir enxerto e cicatriz e não se comprovando que as vesículas se originam no enxerto admite-se que se originam da cicatriz e, que esta hipótese, tem a favor a suscetibilidade dos tegumentos resultantes de epitelização à formação de vesículas atribuídas à imperfeita neoformação da membrana basal.

O objetivo deste estudo foi pesquisar se ocorrem alteração na estrutura da trasição dermoepidérmica - TDE - da pele enxertada que pudesse predispor à formação de vesículas.

A comparação da morfologia das amostras, por meio da análise histológica das lâminas por microscopia ótica, mostrou a integridade da pele com a visualização de todas as camadas da epiderme e da derme, apêndices dérmicos e, principalmente, a presença das papilas dérmicas tanto nas das Amostras AD (Figura 13) como nas ENX (Figura 14). Não houve diferenças estruturais nas 23 amostras analisadas de AD e nas 23 de ENX.

O estudo anatomopatológico por microscopia de luz comparou as medidas lineares ente a epiderme e a transição dermoepidérmica, adotando a camada granulosa como referência da epiderme (Figura 10), pois a 
camada córnea, após o preparo das lâminas, apresentava superfícies irregulares (devido aos artefatos técnicos) as quais poderiam acarretar um resultado impreciso nas aferições.

Para esta análise, em cada amostra foram feitas em média 3 lâminas. Em ambas as amostras houve manutenção do mesmo padrão morfológico (Figuras 13 e 14).

O cálculo do comprimento da epiderme (EPI) e o da transição dermoepidérmica (TDE), das amostras AD e ENX, foi feito pelo software Image J. Havia dois softwares a serem escolhidos: o UTHSCSA Image Tool (desenvolvido pela University of Texas Health Science Center em San Antonio) e o Image J (desenvolvido por Wayne Rasband do Research Services Branch, National Institute of Mental Health, Bethesda, Maryland). Um terceiro software foi cogitado, o Scion Image, porém foi constatado que este era baseado no software Image J. Devido ao desempenho e às facilidades apresentadas, o software Image $\mathrm{J}$ foi escolhido para 0 desenvolvimento deste trabalho (Figura 7).

A aferição das medidas utilizou o índice "TDE/EPI=N" tanto na $A D$ como na ENX (Tabelas 4 e 5). Os resultados dessa aferição mostraram um aumento, no comprimento da área enxertada (ENX) com relação ao da área doadora (AD) (Tabela 5, Figura 15).

No processo da cicatrização de feridas são identificadas três fases: a inflamatória ou inicial, a proliferativa ou de fibroplasia, e a maturação ou remodelação. Estas fases são separadas apenas didaticamente, ocorrendo na realidade superposição e transição contínua e gradual de uma fase para outra. 
A fase inflamatória inicia-se imediatamente após a lesão, e envolve fenômenos vasculares, coagulação sanguínea, migração de células inflamatórias e liberação de fatores de crescimento.

A fase de fibroplasia é caracterizada pela formação do tecido de granulação e pela contração tecidual. O tecido de granulação é formado na área de lesão a partir do $4^{\circ}$ dia, e contém numerosos capilares neoformados, macrófagos, fibroblastos e matriz extracelular. Inicialmente, os fibroblastos produzem fibronectina e colágenos tipos I, III, V e VI. A fibronectina é uma glicoproteína secretada em associação à fibrina que serve de substrato para a migração celular e a fibrilogênese do colágeno, e como sítio de ligação para os miofibroblastos exercerem a contração tecidual.

Gradualmente, passa-se à remodelação desta matriz por meio da contração tecidual, processo biológico que diminui a dimensão dos tecidos conectivos envolvidos na lesão. O processo de contração pode levar a graves contraturas funcionais e sequelas estéticas no caso de queimaduras ${ }^{93}$.

Lembramos que em enxertias de pele existe o fenômeno da retração primária, que é a retração do enxerto logo após este ter sido excisado à custa da derme. Quanto mais espesso for o enxerto, mais espessa será a derme nele contida e maior será a retração primária. Outro fenômeno é o da retração secundária, que é a retração do leito receptor no processo de cicatrização que se inicia na fase de fibroplasia. Estes dois fenômenos poderiam explicar o aumento da relação N=TDE/EPI nas amostras ENX ${ }^{94}$.

Também pudemos verificar que em três casos as medidas da relação TDE/EPI=N de $A D$ foram maiores que as medidas de medidas da relação 
TDE/EPI=N de ENX (Tabela 3). A idade destes pacientes era 38, 20 e 22 anos respectivamente. As áreas doadoras foram os membros inferiores (coxas) e o leito receptor perna direita, perna esquerda e membro superior direito (Tabela 3). Observamos que não houve variação significativa entre as idades dos pacientes e todas as áreas doadoras foram semelhantes. As áreas enxertadas diferiram apenas no terceiro caso aqui mencionado a qual não foi em perna e sim em membro superior. Não sabemos a que atribuir esta alteração, uma vez que todas as amostras do estudo foram executadas com o mesmo método já mencionado.

A análise estatística mostrou, segundo as tabelas 7 e 8 , que houve aumento na relação $\mathrm{N}=\mathrm{TDE} / \mathrm{EPI}$ das amostras ENX, porém não houve alteração ou diferença na homogeneidade das duas amostras. De acordo com a Tabela 8 e Figura 16, pode-se observar que ocorre um aumento de, em média, $27 \%$ de Enxerto em relação à Área doadora $(p=0,002$ para 0 teste $\mathrm{t}$ de Student pareado). Essa diferença é considerada estatisticamente significante $(p<0,05)$.

Apesar do aumento da relação N=TDE/EPI nos enxertos, comprovado pela análise estatística, a análise microscópica demonstrou que esse fato não traz relevância clínica, pois houve manutenção do padrão morfológico da estrutura dos enxertos (Figuras 13 e 14).

O imunomapeamento por imunofluorescência direta, mostrou a presença de todas as camadas da zona da membrana basal onde foi verificada a existência de fluorescência direta e contínua nas amostras $A D$ e ENX (Tabelas 9 e 10). Houve manutenção da integridade das quatro 
camadas na ZMB dos enxertos de pele. Este dado foi de suma importância para este estudo pois a ausência de alterações estruturais na TDE, que impedem a má aderência da epiderme com a derme, reforça a hipótese de que vesículas subepidérmicas não se formariam em enxertos de pele.

Os enxertos de pele de espessura parcial, constituídos por epiderme, papilas dérmicas e membrana basal normais, previnem a epitelização e áreas cicatriciais, e são menos suscetíveis a formação de vesículas. Esta hipótese foi comprovada por meio deste estudo, onde foi pesquisada e comparada a morfologia e estrutura da transição dermoepidérmica (TDE), por meio da integridade da membrana basal onde se observou a normalidade dessas estruturas tanto na área doadora - pele sã - como nos enxertos de pele após a integração dos mesmos (Figuras 17 a 24). 
7 CONCLUSÃO 
1- As estruturas microscópicas das amostras ENX permaneceram iguais às das amostras AD.

2- O padrão morfológico da transição dermoepidérmica (TDE) foi o mesmo nas amostras AD e ENX.

3- A integridade e a continuidade das estruturas da membrana basal foram comprovadas pelo imunomapeamento em ambas as amostras.

4- Nas amostras estudadas, a transição dermoepidérmica (TDE) dos enxertos é igual à da pele sã, doadora, não existindo nos enxertos a predisposição à formação de vesículas. 


\section{ANEXOS}


ANEXO A - Termo de Consentimento Livre e Esclarecido

TERMO DE CONSENTIMENTO LIVRE E ESCLARECIDO

(Instruções para preenchimento no verso)

\section{I - DADOS DE IDENTIFICAÇÃO DO SUJEITO DA PESQUISA OU RESPONSÁVEL LEGAL}

1. Nome do paciente

Documento de Identidade $\mathrm{n}^{\circ}$

Data de Nascimento:

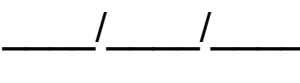

Sexo: $M(\quad) F(\quad)$

Endereço

Bairro

CEP:

DDD:

2. Responsável legal

Natureza (grau de parentesco, tutor, curador, etc:

Documento de Identidade $\mathrm{n}^{\circ}$

Data de Nascimento:

Endereço

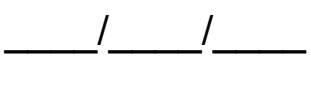

Cidade:

CEP:

Telefone:

Sexo: $M(\quad) F(\quad)$

$\mathrm{N}^{\circ}$

Apart.

DDD:

II - DADOS SOBRE A PESQUISA CIENTÍFICA

1. TÍTULO DO PROTOCOLO DE PESQUISA: Estudo da transição dermoepidérmica dos enxertos de pele e sua relação com o surgimento de vesículas nas áreas enxertadas.

PESQUISADOR: Paulo Cezar Cavalcante de Almeida.

2. CARGO/FUNÇÃO: Médico assistente - Divisão de Cirurgia Plástica e Queimaduras. INSCRIÇÃO CONSELHO REGIONAL Nº 38217

UNIDADE DO HCFMUSP: ICHC

3. AVALIAÇÃO DO RISCO DA PESQUISA:

$\begin{array}{lcc}\text { SEM RISCO }(X) & \text { RISCO MÍNIMO } & \text { RISCO MÉDIO } \\ \text { RISCO BAIXO } & \text { RISCO MAIOR } & \end{array}$

(probabilidade de que o indivíduo sofra algum dano como consequência imediata ou tardia do estudo). 
4. DURAÇÃO DA PESQUISA : 6 meses.

III - REGISTRO DAS EXPLICAÇÕES DO PESQUISADOR AO PACIENTE OU SEU REPRESENTANTE LEGAL SOBRE A PESQUISA CONSIGNANDO:

1. justificativa e os objetivos da pesquisa: Quando há cura das queimaduras de terceiro grau, em pacientes que foram submetidos a enxertos de pele, alguns estudiosos dizem existir a formação de bolhas sob esses enxertos, devido a alterações nas camadas mais superficiais. Discordamos dessa afirmação e queremos pesquisar para provar que bolhas não surgem em enxertos de pele. O que sabemos, e o que lemos nos livros de medicina, é que bolhas ocorrem em queimaduras superficiais, ou outro tipo de pele semelhante, onde houve uma alteração nas estruturas do tegumento.

Com a intenção de provarmos nossa afirmação é necessário o estudo detalhado das camadas da pele para chegarmos à conclusão de que a nossa afirmação é verdadeira.

OBJETIVO: Pretendemos estudar as camadas da pele enxertada e compará-la com as camadas da pele sã, área doadora, para demonstrar que as bolhas não se formam na pele enxertada.

2. procedimentos que serão utilizados e propósitos, incluindo a identificação dos procedimentos que são experimentais: $O$ estudo será feito com as enxertias de pele de média espessura para a cura das feridas pósqueimaduras conforme a rotina do Serviço de Queimaduras do HC-FMUSP. 
Todos os doentes adultos e capazes que necessitarem de enxertias de pele serão adequadamente esclarecidos quanto à pesquisa a fim de darem seu consentimento.

A biópsia de pele doadora, ou seja, a retirada de um pedaço muito pequeno da pele, com um vazador de $0,5 \mathrm{~mm}$, será feita antes da retirada do enxerto. Este local da retirada de pele será marcado com um fio de nylon e, se após 10 dias o enxerto de pele estiver integrado ao leito receptor, será realizada uma segunda biópsia de pele. Estas amostras depois serão encaminhadas para estudo no laboratório de dermatologia, para se verificar se houve ou não alteração das camadas da pele.

Todos os procedimentos que serão usados, neste trabalho, fazem parte das rotinas do Serviço de Queimaduras e de Dermatologia do HCFMUSP, sem a necessidade de recursos extras de qualquer ordem.

3. desconfortos e riscos esperados: Desconforto próprio de uma biópsia ambulatorial, que é muito pequeno, pois essa biópsia será feita sob anestesia e a retirada da pele com um cortador específico para isso. A dor é inexistente e após 5 dias o local já está curado.

4. benefícios que poderão ser obtidos: Melhorar o conhecimento dos médicos com relação ao surgimento dessas bolhas, que em muitos casos interferem e atrasam a cura dos pacientes. 
5. procedimentos alternativos que possam ser vantajosos para o indivíduo: Pele de doador cadáver poderá ser usada como substituto nos enxertos, porém ela é muito escassa no nosso meio.

\section{IV - ESCLARECIMENTOS DADOS PELO PESQUISADOR SOBRE GARANTIAS DO SUJEITO DA PESQUISA CONSIGNANDO:}

1. acesso, a qualquer tempo, às informações sobre procedimentos, riscos e benefícios relacionados à pesquisa, inclusive para dirimir eventuais dúvidas. - Será dada orientação específica ao paciente.

2. liberdade de retirar seu consentimento, a qualquer momento, e de deixar de participar do estudo, sem que isto traga prejuízo à continuidade da assistência. - Será dada orientação específica ao paciente.

3. salvaguarda da confidencialidade, sigilo e privacidade. - Serão respeitados.

4. disponibilidade de assistência no HCFMUSP, por eventuais danos à saúde, decorrentes da pesquisa será mantida pelo Serviço.

5. viabilidade de indenização por eventuais danos à saúde decorrentes da pesquisa. Não há riscos à saúde envolvidos. 
V. INFORMAÇÕES DE NOMES, ENDEREÇOS E TELEFONES DOS RESPONSÁVEIS PELO ACOMPANHAMENTO DA PESQUISA, PARA CONTATO EM CASO DE INTERCORRÊNCIAS CLÍNICAS E REAÇÕES ADVERSAS.

Paulo Cezar Cavalcante de Almeida - Alameda Joaquim Eugênio de Lima, 1475, Ap. 52 - São Paulo - SP. Telefone residencial: (11) 5575-9248. Telefone celular: (11) 7418-5433

David de Souza Gomez - Alameda Mongaguá, 199 - Santana de Parnaíba SP. Telefone residencial: (11) 4153-2824. Telefone celular: (11) 8353-0011

\section{VI - OBSERVAÇÕES COMPLEMENTARES:}

\section{VII - CONSENTIMENTO PÓS-ESCLARECIDO}

Declaro que, após convenientemente esclarecido pelo pesquisador e ter entendido o que me foi explicado, consinto em participar do presente Protocolo de Pesquisa.
São Paulo,
de
de 2009. 
ANEXO B - Carta de informação

Estudo da transição dermoepidérmica dos enxertos de pele e sua relação com o surgimento de vesículas.

Pretendemos fazer uma pesquisa com a intenção de investigarmos se é verdadeira a afirmação de que vesículas (bolhas de $1 \mathrm{~cm}$ de diâmetro) surgem nos enxertos de pele de pacientes queimados ou se apenas surgem em outras áreas queimadas.

Para este fim é necessário que se estudem duas áreas do corpo. A primeira delas é a área onde vai ser retirado o enxerto, área doadora; e a segunda é a área onde o enxerto foi colocado, área enxertada.

Essa pesquisa tem tempo determinado. Uma vez marcada a data da cirurgia de enxertia de pele ela se inicia e termina 12 dias após o enxerto ter sido realizado.

O estudo vai ser feito da seguinte forma:

No dia da cirurgia, sob anestesia, será realizada uma biópsia, ou seja, será retirada uma pequena parte de pele da área doadora escolhida para o tratamento da queimadura de terceiro grau. Queimadura de terceiro grau é uma queimadura profunda onde toda a pele foi destruída.

Dez a doze dias após será feita uma nova biópsia, também sob anestesia, mas desta vez na área que sofreu o enxerto de pele.

Essas biópsias serão encaminhadas para o laboratório de dermatologia e examinadas para se fazer a comparação da pele sã e da 
pele enxertada. Essa comparação vai nos ajudar esclarecer se realmente as bolhas surgem em áreas de enxerto de pele ou em áreas próximas a eles.

A importância dessa investigação é melhorar o conhecimento dos médicos com relação ao surgimento dessas bolhas, que em muitos casos interferem e atrasam a cura dos pacientes.

As bolhas e as vesículas podem acarretar a perda de enxertos de pele e trazer maior sofrimento e para o paciente.

Os benefícios que este estudo vai trazer é saber realmente como e por que essas bolhas surgem e a maneira mais simples de evitá-las e tratá-las. Não existe nenhum risco potencial à sua saúde se você participar deste protocolo de estudo.

A qualquer momento o médico pesquisador, Dr. Paulo Cezar, estará disponível a prestar maiores esclarecimentos, explicar qualquer dúvida e falar mais a respeito do objetivo desta pesquisa. Para isso, você deverá solicitar a presença dele junto ao seu leito de internação, na enfermaria de queimaduras, ou entrar em contato nos telefones fornecidos.

Você pode a qualquer momento retirar o seu consentimento, se não quiser mais participar do estudo, sem sofrer nenhuma consequência e seguir seu tratamento normalmente.

Todas as informações obtidas serão confidenciais, ou seja, não serão divulgadas em revistas, internet, televisão ou jornais. Os resultados dos estudos serão apenas divulgados em congressos médicos e em revistas especializadas exclusivas para médicos. 
Se você apresentar qualquer complicação relacionada a este estudo, você será tratado aqui no Hospital das Clínicas da Faculdade de Medicina da Universidade de São Paulo, sem nenhum custo.

INFORMAÇÕES E NOMES, ENDEREÇOS E TELEFONES DOS RESPONSÁVEIS PELO ACOMPANHAMENTO DA PESQUISA, PARA CONTATO EM CASO DE DÚVIDAS OU INTERCORRÊNCIAS CLÍNICAS.

Pesquisadores executantes / responsáveis:

Dr. Paulo Cezar Cavalcante de Almeida - Telefone: (11) 5575-9248 Telefone celular: (11) 7418-5433 - Endereço: Alameda Joaquim Eugênio de Lima, $n^{\circ} 1475$, ap. 52, São Paulo - SP.

Dr. David de Souza Gomez - Endereço: Alameda Mongaguá, 199 - Santana de Parnaíba - SP. Telefone: (11) 4153-2824. Celular: (11) 8353-0011.

Enfermaria de Queimaduras - Telefone: (11) 3069-6238, procurar a enfermeira chefe da Unidade D. Maria Aparecida. 
ANEXO C - Aprovação da Comissão de Ética para Análise de projetos de Pequisa CAPPesq

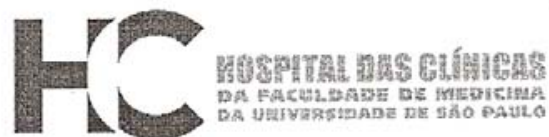

\section{APROVAÇÃO}

A Comissão de Ética para Análise de Projetos de Pesquisa - CAPPesq da Diretoria Clínica do Hospital das Clínicas e da Faculdade de Medicina da Universidade de São Paulo, em sessão de 22/08/2007, APROVOU O Protocolo de Pesquisa $n^{\circ}$ 0276/07, intitulado: "ESTUDO DA TRANSIÇÃO DERMO-EPIDÉRMICA DOS ENXERTOS DE PELE PARA ESCLARECER A CAUSA DO SURGIMENTO DE VESÍCULAS NAS ÁREAS ENXERTADAS" apresentado pelo Departamento de CIRURGIA, inclusive o Termo de Consentimento Livre e Esclarecido.

Cabe ao pesquisador elaborar e apresentar à CAPPesq, os relatórios parciais e final sobre a pesquisa (Resolução do Conselho Nacional de Saúde $n^{\circ} 196$, de 10/10/1996, inciso IX.2, letra "c").

Pesquisador (a) Responsável: Dra. Mônica Mathor

Pesquisador (a) Executante: Dr. Paulo Cezar Cavalcante de Almeida CAPPesq, 31 de Agosto de 2007

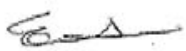

Prof. Dr. Eduardo Massad Presidente da Comissāo de Ética para Análise de Projetos de Pesquisa

Comissåo de Ética para Análise de Projetos de Pesquisa do HCFMUSP e da FMUSP Diretorla Clinica do Hospital das Clinicas da Faculdade de Medicina da Universidade de São Paulo Rua Ovidio Pires de Campos, 255, $5^{\circ}$ andar - CEP 05403010 - São Paulo - SP Fone: 0113069 6442 Fax: 01130696492 e-mail: cappesq@honet.usp.br / gecretariacappesq2@hcnet.usp.br -sol 


\section{ANEXO D - Tabela gerada pelo DATASUS/TABWIN}

Tabela gerada pelo DATASUS/TABWIN - Produção Hospitalar - em 13 de fevereiro de 2009, de acordo com o CID 10 (Queimadura), enviada como anexo no e-mail citado na referência 37

\begin{tabular}{|c|c|c|c|c|}
\hline \multicolumn{5}{|c|}{ Ano 2006} \\
\hline UF int & Frequência & Óbitos & Permanência & Diárias de UTI \\
\hline Rondônia & 164 & - & 1.506 & 4 \\
\hline Acre & 48 & - & 404 & - \\
\hline Amazonas & 52 & - & 309 & - \\
\hline Roraima & 9 & - & 50 & 7 \\
\hline Pará & 1.028 & 5 & 5.788 & 52 \\
\hline Amapá & 110 & - & 1.132 & - \\
\hline Tocantins & 411 & 2 & 2.018 & 25 \\
\hline Maranhão & 571 & 4 & 3.266 & 59 \\
\hline Piauí & 283 & 8 & 2.077 & - \\
\hline Ceará & 1.435 & 37 & 9.173 & 89 \\
\hline Rio Grande do Norte & 235 & 10 & 2.288 & - \\
\hline Paraíba & 1.275 & 31 & 8.010 & 37 \\
\hline Pernambuco & 2.317 & 51 & 20.023 & 156 \\
\hline Alagoas & 481 & 8 & 4.002 & - \\
\hline Sergipe & 582 & 9 & 4.674 & 76 \\
\hline Bahia & 2.717 & 69 & 16.544 & 132 \\
\hline Minas Gerais & 3.868 & 135 & 30.599 & 2.734 \\
\hline Espírito Santo & 640 & 8 & 7.296 & 915 \\
\hline Rio de Janeiro & 1.352 & 87 & 15.753 & 569 \\
\hline São Paulo & 6.330 & 208 & 49.724 & 10.219 \\
\hline Paraná & 2.247 & 54 & 13.986 & 359 \\
\hline Santa Catarina & 925 & 8 & 6.821 & 154 \\
\hline Rio Grande do Sul & 1.974 & 52 & 14.179 & 718 \\
\hline Mato Grosso do Sul & 445 & 19 & 4.298 & 138 \\
\hline Mato Grosso & 454 & 9 & 2.957 & 71 \\
\hline Goiás & 3.072 & 24 & 10.028 & 1.072 \\
\hline Distrito Federal & 659 & 5 & 4.354 & 28 \\
\hline Total & 33.684 & 843 & 241.259 & 17.614 \\
\hline
\end{tabular}


ANEXO E - Tabela gerada pelo SIM (Sistema de Informação sobre Mortalidade), Ministério da Saúde

Tabela gerada pelo SIM (Sistema de Informação sobre Mortalidade), Ministério da Saúde. Essa fonte de informação registra todos os óbitos ocorridos dentro e fora de ambientes hospitalares.

\begin{tabular}{cc}
\hline \multicolumn{2}{c}{ Mortalidade - Brasil - 2006 - SIM } \\
\hline \multicolumn{2}{c}{ Exposição à fumaça, ao fogo e às chamas } \\
& Período:2006 \\
\hline Região & Total \\
\hline Região Norte & 58 \\
Região Nordeste & 213 \\
Região Sudeste & 390 \\
Região Sul & 233 \\
Região Centro-Oeste & 57 \\
\hline Total & 951 \\
\hline
\end{tabular}


9 REFERÊNCIAS 
1. Gallico GG, O' Connor NE, Comptom CC, Kehinde O, Green H. Permanent coverage of large wounds with autologous cultured human epithelium. N Engl J Med. 1984;311:448-51.

2. O'Connor NE, Mulliken JB, Banks-Schlegel S, Kehind T, Green H. Grafting of burns with cultured epithelium prepared form autologous epidermal sells. Lancet. 1981;1:75-8.

3. Cuono C, Langdon R, McGuire J. Use of cultured epidermal autografts and dermal allografts as skin. Lancet. 1986;17:1132-4.

4. De Lucca M, Albanese E, Bondanza S. Multicentre experience in he treatment of Burns with autologous and allogenic cultured epithelium, fresh or preserved in frozen state. Burns. 1989;15:303-9.

5. Teepe RGC, Kreis RW, Koebrugge EJ. The use of cultured autologous epidermis in the treatment of extensive burn wounds. J Trauma. 1990;30:1-7.

6. Donati L, Magliacani G, Bormioli M, Sigmorini M, Preis FW. Clinical experiences with keratinocyte grafts. Burns. 1992;18(Suppl 1):S19-26.

7. Herson MR. Estudo da composição in vitro de substituto cutâneo dermoepidérmico constituído por epitélio de queratinócitos cultivados sobre base dérmica alógena [tese]. São Paulo: Faculdade de Medicina, Universidade de São Paulo; 1999.

8. Barker DJ, Cotteril JA. Development of subepidermal bullae in the split skin graft donor site of a psoriatic. Dermatologica. 1980; 160:311-4.

9. Berman A. Bullae in the donor site of split thickness skin graft. $J$ Dermatol Surg Oncol. 1982;8:291-2. 
10. Baran R, Juhlin L. Bullae in skin grafts. Br J Dermatol. 1984;3:221-5.

11. Pedragosa R, Serrano S, Carol-Murillo J, Hernandez JV, Vidal J. Blisters over burn scars in a child. Br J Dermatol. 1986;115:501-6.

12. Epstein A, Hendrick SJ, Sanchez RL, Salomon RR, Fine JD. Persistent subepidermal blistering in split-thickness skin graft sites. Arch Dermatol. 1988;124:244-9.

13. Woodley DT, Peterson HD, Herzog, SR. Burn wounds resurfaced by cultured epidermal autografts show abnormal reconstitution of anchoring fibrils. JAMA. 1988;259:2566-71.

14. Chetty BV, Boissy RE, Warden GD, Nardlund JJ. Basement membrane and fibroblast aberration in blisters at the donor, graft and spontaneous healed sites in patients with burns. Arch Dermatol. 1992;128:181-6.

15. Bergman R, David R, Ramon R. Delayed post burn blisters: an immunohistochemical and ultrastructural study. J Cutan Pathol. 1997;24:429-33.

16. Gomez DS, Mariani U, Ferreira MC. The problem of subepidermal blisters in neoformed integuments. Burns. 2005;31:811-3.

17. Mariani U, Gomez DS, Carvalho DA, Ferreira MC. The tegument resulting from the healing of burns. Rev Hosp Fac Med São Paulo. 1995;50:140-6.

18. Epstein A, Henridrick SJ, Sanchez RR, Salomon RR, Fine JD. Persistent subepidemal blistering in split-thickness skin graft site. Arch Dermatol. 1988;124:244-9.

19. Secretaria de Saúde e Defesa Civil, Coordenação Estadual de Queimaduras do Estado Rio de Janeiro. Histórico das queimaduras. [citado jan 2009]. Disponível em: http://www.saude.rj.gov.br/queimaduras/historico.html. 
20. Artz CP, Moncrief JA; Pruit BA. Histórias das Queimaduras. In: Queimaduras. Rio de Janeiro: Interamericana; 1980; cap 1, p 1-13.

21. Chong AJ, Klein MB. Marjolin's ulcer. N Engl J Med. 2005;9:352.

22. Mc Carthy JG. Physical properties of skin, thermal burns. In: Plastic surgery. Philadelphia: W B Saunders;1990. v.1, cap 23, p.787-813.

23. Vander Elst E. Historical aspects of the treatment of Burns. In: Lorthoior J, editor. Physiophatology and treatment of burns. Brussels: Presses Académiques Europeénes; 1964. p.1-23.

24. The treatment of burns: an historical perspective with emphasis on the hand. Hand Clin. 1990;6:163-90.

25. Historical aspects of burn management. Surg Clin North Am. 1970;50:193-200.

26. It all began with Aristotle - the history of the treatment of burns. Burns. 1988; (Suppl):S1-46.

27. Forjuoh SN. Burns in low and middle income countries: a review of available literature on descriptive epidemiology, risk factors, treatment, and prevention. Burns 2006;32:529-37.

28. Gomes DR, Guimarães Jr LM, Serra MCVF. Condutas atuais em queimaduras. Rio de Janeiro, Revinter; 2001. p.8-54.

29. Gomes DR, Serra MCVF, Pellon MA. Queimaduras. Rio de Janeiro: Revinter; 1995. p.31-7.

30. Serra MCVF. A criança queimada. In: Gomes DR, Serra MCVF, Pelleon MA. Queimaduras. Rio de Janeiro: Revinter; 1995. p.41-66.

31. Herndon DN. Total burn care. $2^{\text {nd }}$ ed. Amsterdan: Elsevier Science; 2001. cap 1, p.11-3. 
32. El Hamaoui Y, Yaalaoui S, Chihabeddine K, Boukind E, Moussaoui D. Post-traumatic stress disorder in burned patients. Burns. 2002;28:647-50.

33. Serra MCVF, Junior EML. Tratado de queimaduras. São Paulo: Atheneu; 2004. cap. 5, p.31-5.

34. Gomes DR, Serra MCVF, Pellon MA. Queimaduras. Rio de Janeiro: Revinter; 1995. p.1-7.

35. Secretaria de Saúde do Estado de São Paulo. Normas Técnicas para o Atendimento de Queimaduras no Sistema de Saúde do Estado de São Paulo. Resolução SS n 642. Diário Oficial do Estado; 199420 dez.

36. Ministério da Saúde. Portarias GM n. 1273, de 21 de novembro de 2000 e 1274 , de 26 de fevereiro de 2001.

37. Leite RMC. Queimadura por CID 10, ano 2006, Ministério da Saúde [mensagem pessoal]. Mensagem recebida por e-mail do destinatário em 17 de fevereiro de 2009.

38. Ministério da Saúde. Departamento de Informática do SUS, DATASUS. [citado jan 2009]. Disponível em: http://w3.datasus.gov.br/datasus/datasus.php.

39. Pam La Borde RN. Burn epidemiology: the patient, the nation, the statistics, and the data resources. Crit Care Nurs Clin North Am. 2004;16:3-25.

40. Elberg JJ, Schrøder HA, Glent-Madsen L, Hall KV. Burns: epidemiology and the effect of a prevention programme. Burns Incl Therm Inj. 1987;13:391-3.

41. Henning Onarheim, Anne Berit Guttormsen, Einar Eriksen. Burn treated at the Haukeland University Hospital Burn Centre - 20 years of experience. Tidsskr Nor Laegeforen. 2008;128:1168-71. 
42. Ghaffar UB, Husain M and Risvi SJ. Thermal Burn: An Epidemiological Prospective Study. J Indian Acad Forensic Med. 2008;30:10-4.

43. ul-Muqim R, Zareen M, Dilbag, Hayat M. Epidemiology and outcome of Burns at Khyber Teaching Hospital Peshawar. Pak J Med Sci. 2007;23:420-24.

44. Tang K, Jian L, Qin Z, Zhenjiang L, Gomez M. Characteristics of burn patients at a major burn center in Shanghai. Burns. 2006;32:1037-43.

45. Pegg PS. Burn epidemiology in the Brisbane and Queensland area. Burns. 2005;31:27-31.

46. Franco MAH, Gonzáles NCJ, Diaz MEM, Pardo SV, Ospina S. Epidemiological and clinical profile of burn victims Hospital Universitário de San Vicente de Paul, Mendelin, 1994-2004. Burns. 2006;32:1044-51.

47. Gardner E, Gray D, O’Rahilly R. Anatomia: estudo regional do corpo humano. $4^{\mathrm{a}}$ ed. Rio de Janeiro: Guanabara Koogan; 1985. cap. 1, p.50-58.

48. Campedelli MC, Gaidzinsky RR. A metodologia assistencial de enfermagem na prática - Hospital Universitário da USP. Rev Esc Enferm USP. 1987;21(n esp):62-7.

49. Bryant AR. Acute and chronic wounds nursing management. In: Wysocki BA, Bryant AR. Skin. St. Louis: Mosby Yearbook; 1992. p.1-30.

50. Irion GI. Feridas, novas abordagens, manejo clinico e atlas em cores. Rio de Janeiro: Guanabara Koogan; 2005. cap. 4, p.3-15.

51. Bear MF, Connors BW, Paradiso MA. Anatomia da pele. Neurociênciasdesvendando o sistema nervoso. $2^{\mathrm{a}}$ ed. Porto Alegre: Ed. Artmed; 2002. p.85-7.

52. Bolognia J, Jorizzo J, Rapini R. Dermatology. Amsterdan: Elsevier; 2003. v. 1 , cap. 4 , p.39-48. 
53. Loomis CA, Birge MB. Fetal Skin Development. In: Eichenfield LF, Frieden IJ, Esterly NB. Textbook of neonatal dermatology. Philadelphia: WB Saunders; 2001. p.1-17.

54. Online Mendelian Inheritance In: Man (OMIM). National Center for Biotechnology Information. [cited 2009 jan 20]. Available from: http://www.ncbi.nlm.nih.gov:80/entrez/query.fcgi?db=OMIM.

55. Junqueira LCU, Carneiro J. Histologia básica. 9a ed. São Paulo: Guanabara-Koogan; 1999. p.46-66.

56. Margulies DH. Interacitons of TCRs with MHC - peptide complexes: A quantitative basis for mechanistic models. Curr Opin Immunol. 1997;9:390-5.

57. Stingl G, Kate SI, Clement L, Green I., Shevach EM. Immunologic functions of la-bearing epidermal Langerhans cells. J Immunol. 1978;121:2005-13.

58. Alberts, B; Bray, D; Lewis, J; Raff, M; Roberts, K; Watson, J. D. Biologia molecular da célula. $3^{a}$ ed. Porto Alegre: Artes Médicas; 1997. p.787-862.

59. Dângelo JG, Fattini CA. Anatomia humana sistêmica e seguimentar. $2^{\mathrm{a}}$ ed. Rio de Janeiro: Atheneu; 1988. p.101-2.

60. Junqueira LCU, Carneiro J. Tecidos conjuntivos. In: Junqueira LCU, Carneiro J, editores. Histologia básica. 9a ed. São Paulo: GuanabaraKoogan; 1999. p.67-91.

61. Tarquinio SBC. Estudo de componentes da Matriz Extracelular no líquen Plano, Penfigóide benigno da mucosa e Pênfigo Vulgar [tese]. São Paulo: Faculdade de Odontologia, Universidade de São Paulo; 1999.

62. Stanley P Jr, Hawley N, Yuspa SH, E.M Shevach EM, Katz SI. Characterization of bullous pemphigoid antigen: a unique basement membrane protein of stratified squamous epithelia. Cell. 1981;24:897-903. 
63. Chan LS, Fine JD, Briggaman RA, Woodley DT, Hammerberg CRJ. Drugge RJ, Cooper KD. Identification and partial characterization of a novel 105-kDalton lower lamina lucida autoantigen associated with a novel immune-mediated subepidermal blistering disease. $\mathrm{J}$ Invest Dermatol. 1993;101:262-7.

64. Universidade Federal de Minas Gerais (UFMG). Epitélios de revestimento. [citado 1 fev 2009]. Disponível em: http://www.icb.ufmg.br/mor/biocelch/material_fto_greg/epitelio_revestime nto.ppt.

65. Abrahamson DR. Recent studies on the structure and pathology of basement membranes. J Pathol. 1986;149:257-78.

66. Murphy GF. Histology of the skin. In: Elder D, Elenitsas R, Jaworsky C, Johnson B, editors. Lever's histopathology of the skin. $8^{\text {th }}$ ed. Philadelphia: Lippincott-Raven; 1997. p.17-9.

67. Chan LS, Majmudar AA, Tran HH. Laminin-6 and laminin-5 are recognized by autoantibodies in a subset of cicatricial pemphigoid. $J$ Invest Dermatol. 1997;108:848-53.

68. Chan LS. Human skin basement membrane in health and in autoimmune diseases. Front Biosci. 1997; 15:343-52.

69. Kuhn K. Basement membrane (type IV) collagen. Matrix Biol. 1994;14:439-45.

70. Chan LS, Majmudar AA, Tran HH, Meier F, Schaumburg-Lever G, Chen M, Anhalt G, Woodley DT, Marinkovich MP. Laminin-6 and laminin-5 are recognized by autoantibodies in a subset of cicatricial pemphigoid. $J$ Invest Dermatol. 1997;108:848-53.

71. Sakai LY, Keene DR, Morris NP, Burgeson RE. Type VII collagen is a major structural component of anchoring fibrils. $\mathrm{J}$ Cell Biol. 1986;103:1577-86. 
72. Gibson IK, Spurr-Michaud SJ, Tisdale AS. Anchoring fibrils form a complex network in human and rabbit cornea. Invest Ophthalmol Vis Sci. 1987;28:212-20.

73. Keene DR; Sakai LY; Bächinger HP; Burgeson RE. Type III collagen can be present on banded collagen fibrils regardless of fibril diameter. $J$ Cell Biol. 1987;105:2393-402.

74. Hopkinson I, Anglin IE, Evans DL, Harding KG. Collagen VII Expression in human chronic wounds and scars. J Pathol. 1997;182:192-6.

75. Morais LOC, Lodi FR, Marques SR, Oshima CTF, Fernandes Junior JA, Smith RL, Alonso LG. Expressão imuno-histoquímica do anticorpo de colágeno tipo VII no disco articular da articulação temporomandibular de fetos humanos. Einstein. São Paulo. 2007;5:333-6.

76. Pulkkinen L, Christiano AM, Gerecke D, Wagman DW, Burgeson RE, Pittelkow MR, Uitto J: A homozygous nonsense mutation in the beta 3 chain gene of laminn 5 (LAMB3) in Herlitz junctional epidermolysis bullosa. Genomics. 1994;24:357-60.

77. Vidal F, Aberdam D, Miquel C, Christiano AM, Pulkkinen L, Uitto J, Ortonne JP, Meneguzzi G. Integrin beta 4 mutations associated with junctional epidermolysis bullosa with pyloric atresia. Nature Genet. 1995;10:229-34.

78. Cucé LC, Festa Neto C. Dermatology in general medicine. $2^{a}$ ed. São Paulo: Atheneu; 2001. p.1-11.

79. Sampaio SP, Rivitti EA. Pele normal: anatomia e fisiologia. In: Dermatologia. São Paulo: Artes Médicas; 1988. p.4-35.

80. Junqueira LCU, Carneiro J. Tecidos conjuntivos. In: Junqueira LCU, Carneiro J. Histologia básica. 9a ed. São Paulo: Guanabara-Koogan; 1999. cap. 18, p.303-14. 
81. Isaac C. Estudo in vitro da ação de pentoxifilina em fibroblastos oriundos de cicatrizes hipertróficas pós queimaduras de pele não cicatricial [tese]. São Paulo: Faculdade de Medicina, Universidade de São Paulo; 2007.

82. Bélico MFDS. Análise mecânica e histologia do tegumento facial com seqüela de queimadura após tratamento tópico com tretinoína [tese]. São Paulo: Faculdade de Medicina, Universidade de São Paulo; 2008.

83. Guirro E, Guirro, R. Fisioterapia dermato-funcional: fundamentos, recursos, patologias. $3^{a}$ ed. São Paulo: Manole; 2004. Cap.1, p.3-13.

84. Mc Carthy C, editor. Skin grafts. In: Plastic surgery. Philadelphia: W B Saunders; 1990. v. 1, p.222.

85. Bolognia J, Jorizzo J, Rapini R. Overview of basic science. In: Dermatology. Amsterdan: Elsevier; 2003. v.1, p.1-22.

86. Gomez DS, Almeida PCC. Tratado de medicina de reabilitação. Reabilitação do grande queimado. aspectos gerais no tratamento do queimado. tratamento cirúrgico do queimado. São Paulo: Livraria Rocca; 2007. p.1228-36.

87. Herndon DN. Total burn care. $2^{\text {nd }}$ ed. Amsterdan: Elsevier Science; 2001. p.127-35.

88. Image J. Software. Programa de domínio público [citado 21 set 2007]. Disponível em: http://rsb.info.nih.gov/ij/.

89. Image J. Image tool help standard manual [citado 21 set 2007]. Disponível em: http://3d2f.com/tags/3d/image/toll/.

90. Dias FC. Uso do software Image J para análise quantitativa de imagens de microestruturas de materiais [dissertação]. [citado 15 out 2008]. São José dos Campos: Instituto Nacional de Pesquisas Espaciais; 2008. Disponível em: http://urlib.net/sid.inpe.br/mtcm17@80/2008/04.30.20.23. 
91. Benseñor IM, Lotufo PA. Epidemiologia: abordagem prática. São Paulo: Sarvier; 2005. p.138-56.

92. Kannan S, Balaram P, Chandran GJ, Pillai MR, Mathew B, Nalinakumari $\mathrm{KR}$, et al. Alterations in expressions of basement membrane proteins during tumor progression in oral mucosa. Histopathology. 1994;24:531-7.

93. Fundamentos da Medicina estética. Reparação tecidual. Disciplina de Cirurgia Plástica e Queimaduras, HCFMUSP. [Curso on-line] cap. 4, Disponível em: http://www.plastica.fm.usp.br/estetica/capitulo-4.htm. [ciatdo 17 jan 2009].

94. Mc Carthy JG. Skin grafts. In: Plastic surgery. Philadelphia: W B Saunders; 1990. v. 1, cap. 8, p.243.

95. Geofrey Davis MM, Boniface JJ, Reich Z, Lyons D, Hampl J, Ardem B, Chien Y. Ligand recognition by a/b T cell receptors. Annu Rev Immunol. 1998;16:423-44.

96. Hiatt JL, Gartner LP. Tratado de histologia. $2^{\mathrm{a}}$ ed. Rio de Janeiro: Guanabara Koogan; 1999. p.25-96: Epitélio e glândulas.

97. Chan LS, Woodley DT. The 105-kDa basement membrane autoantigen p105 is N-terminally homologous to a tumor-associated antigen. J Invest Dermatol. 1996;107:209-14.

98. Bolognia J, Jorizzo J, Rapini R. Dermatology. Amsterdan: Elsevier; 2003. v. 1 , cap. 30, p.445-8. 
APÊNDICES 


\section{Metodo}

o estudo sera feito un docutes a serem subructidos a enkertia de pele de espessura parcial pora o trata. necto de queinuaduas, conforme rotiva adotada no Servico.

\section{.}

Todas as dvectes suā adequadamente enclorecidos quonto a pergirise que

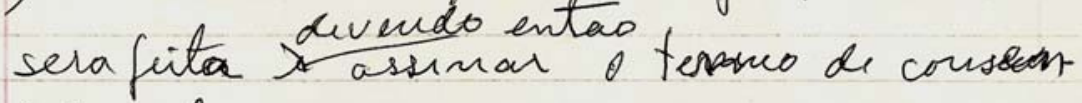
finucuto.

Durante a enxerlia de pele sera ferta uivia biefsra da árca deradora, cone vasoder des smilinetros, antes de excisoo do enterto. que sera a omastra podras da trousicoó derno efudernica: Amortia Padio- AD.

o tralanento pos-euxertia tera fieto sejundo a rotina.

Apêndice 1. Manuscrito de Mariani na época em que idealizou o trabalho sobre o surgimento de vesículas em enxertos de pele. 


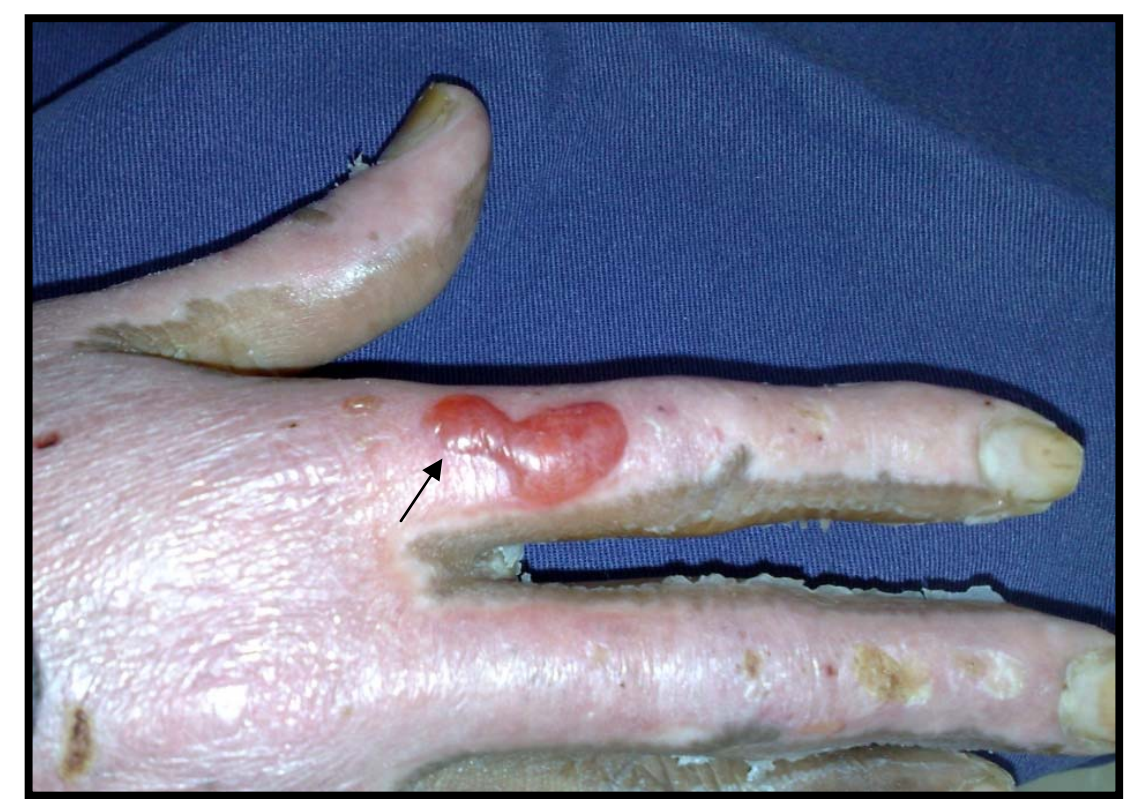

Apêndice 2. Figura de bolha em queimadura de segundo grau curada.

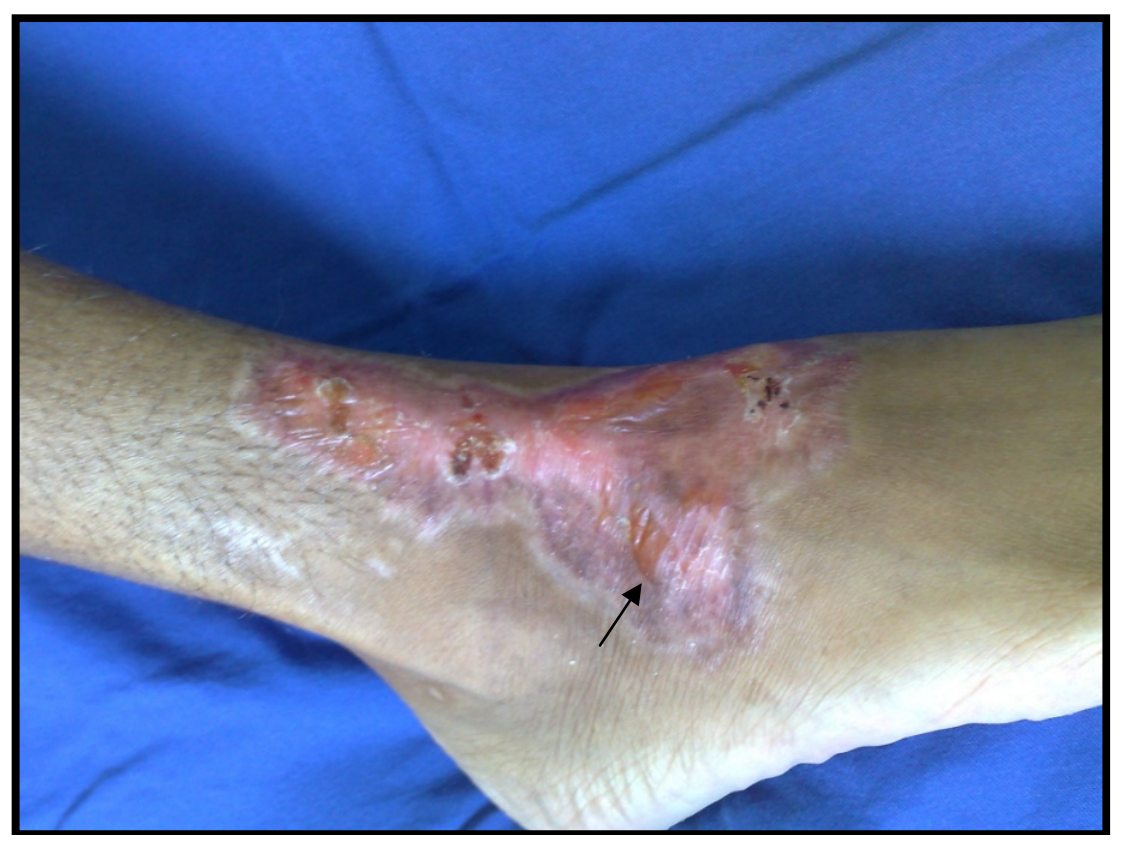

Apêndice 3. Figura de vesícula em cicatriz pós queimadura de terceiro grau de pé (cicatrização por segunda intenção). 


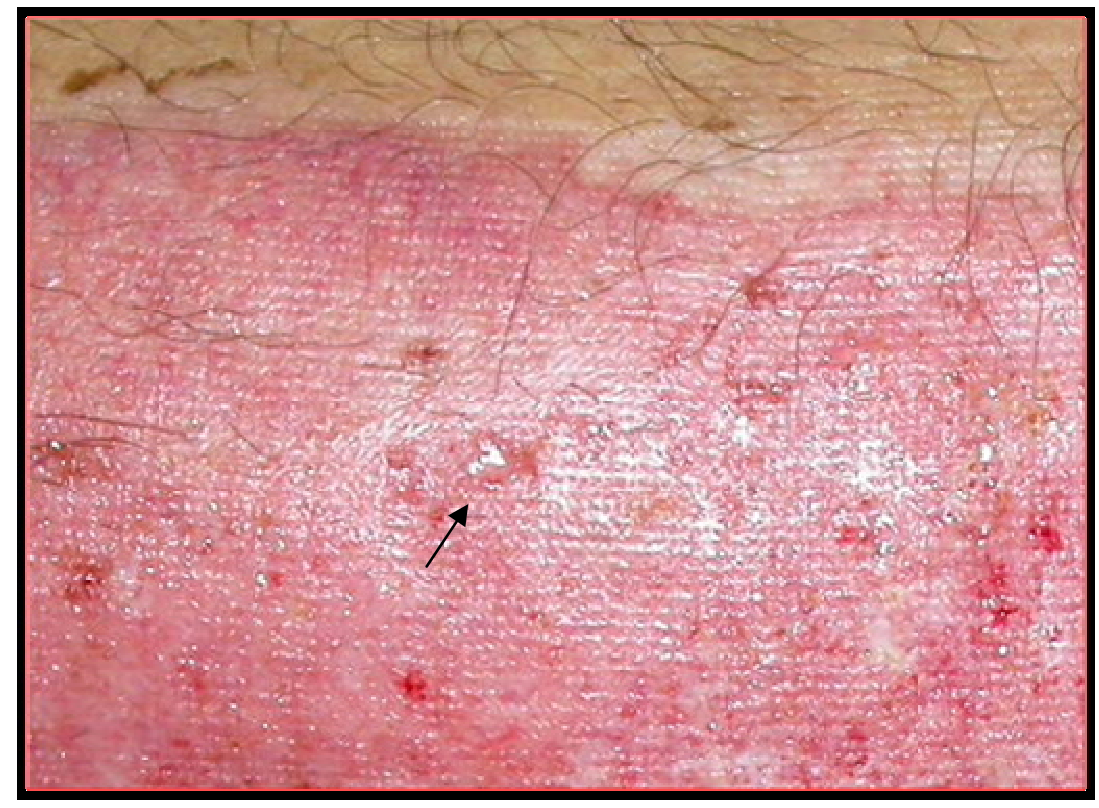

Apêndice 4. Figura de vesícula em área doadora.

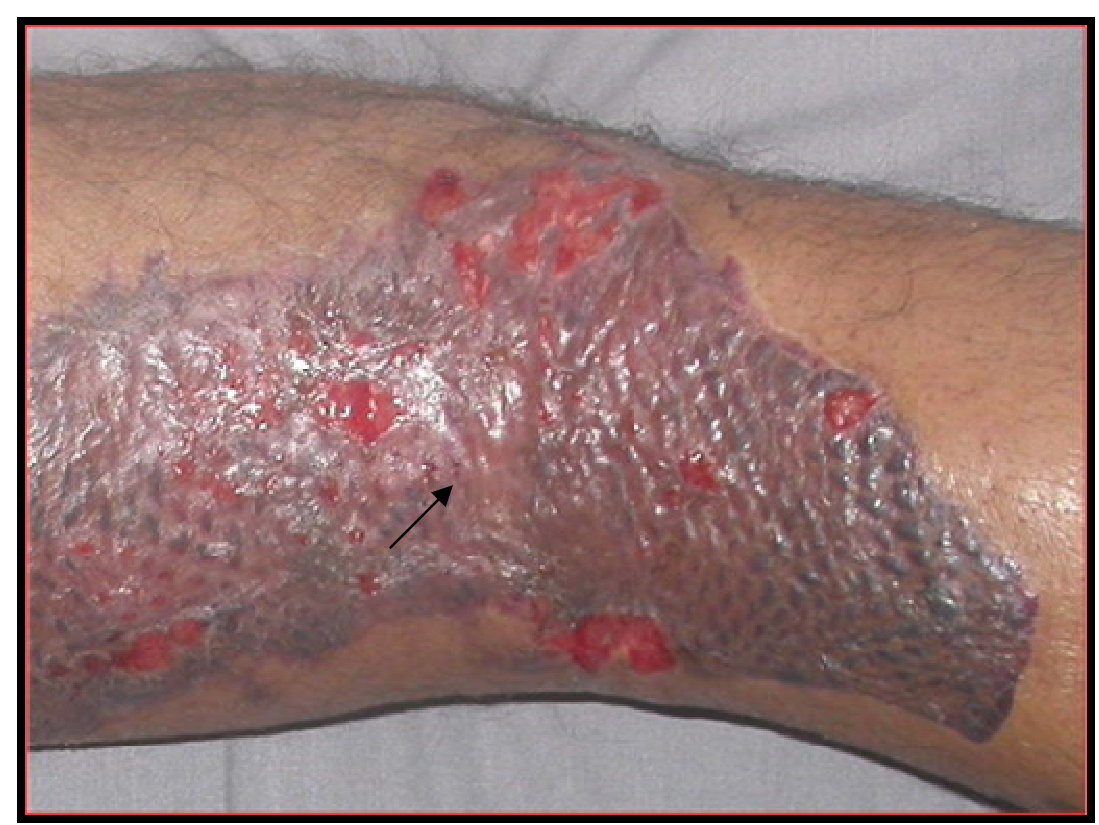

Apêndice 5. Figura de vesícula em enxerto em malha. 